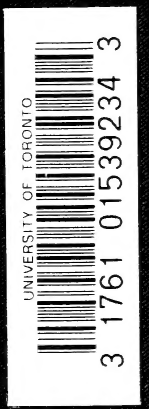

THE

Forest Tree Planteris Mulaueu

10TH EDITION.

143

E35

1894 


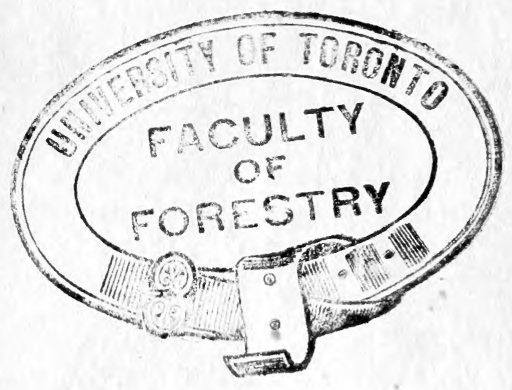




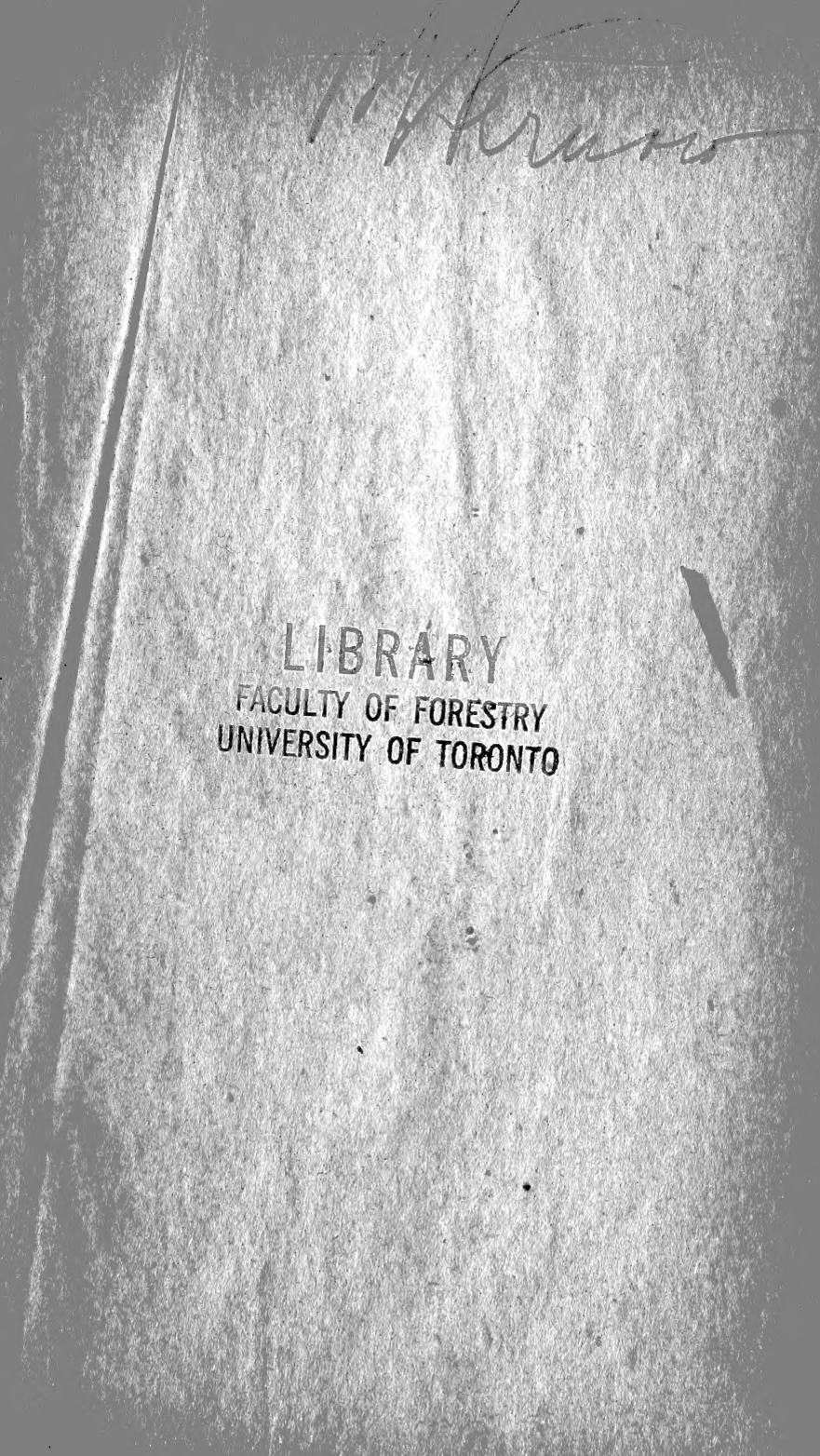




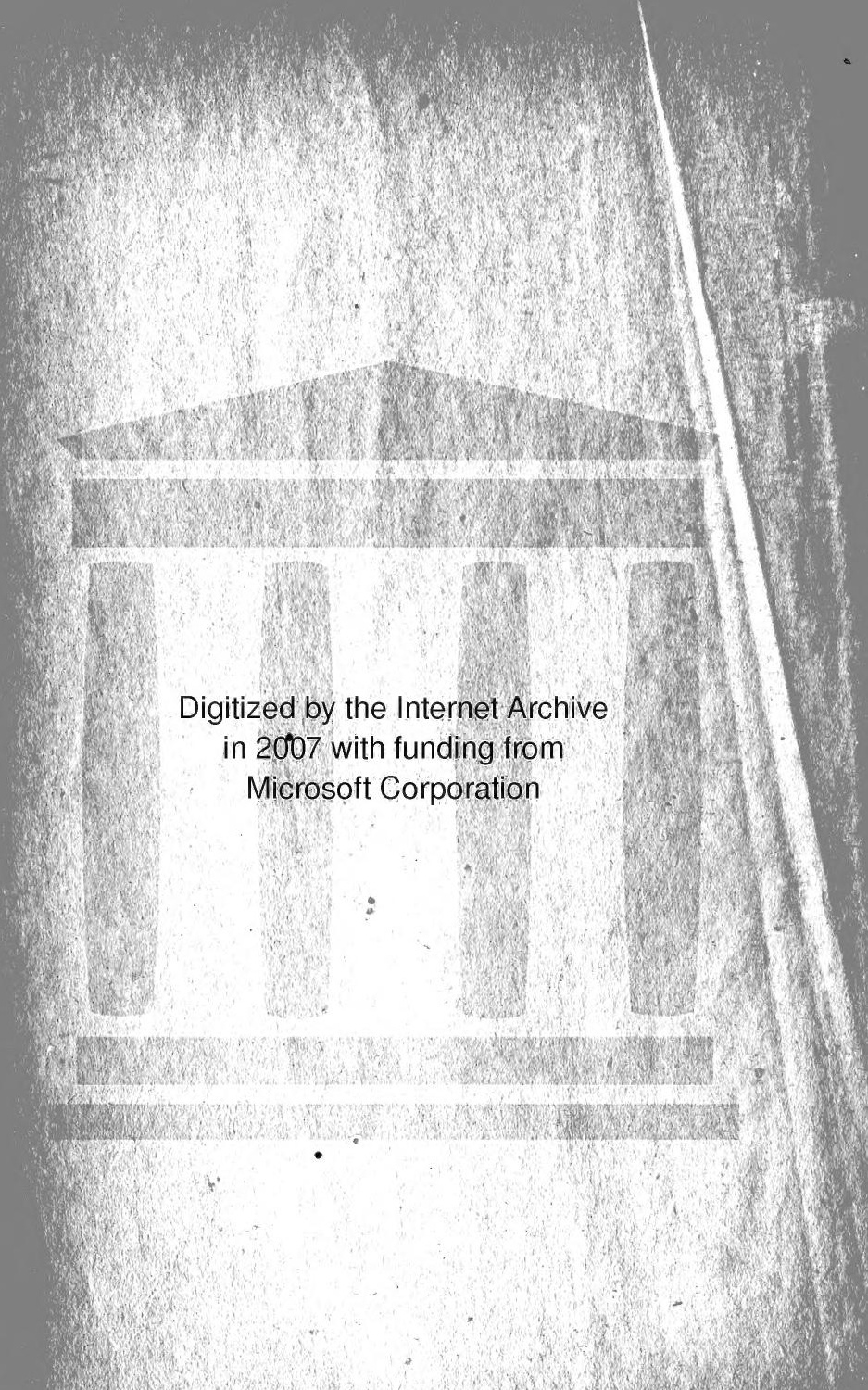

http:/www.archive.org/details/foresttreeplante00barruoft 


\section{THE}

\section{POREST TREE PLAITER'S}

\section{MANUAL.}

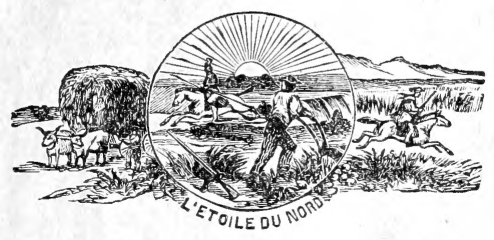

TENTH EDITION.

BY

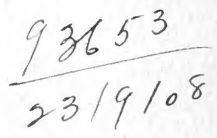

Secretary of the State Forestry Association.

MINNEAPOLIS, MINN.

Published by

The Progressivis Age Publishing Co., MINNEAPOLIS, MINN. 


\section{OFFICERS OF THE ASSOCIATION FOR 1894.}

John H. Stevens,

J. O. BARRETT,
President.

Treasurer and Secretary.

VICE-PRESIDENTS.

First Congressional District, Wm. Somerville, - - Viola, Minn

Second " "

Third "

Fourth " "

Fifth "6

Sixth “6

Seventh “
Alfred Terry, - - Slayton, Minn.

N. F. Brand, - - Faribault, Minn.

R. S. MacIntosh, - - Langdon, Minn.

S. M. Owen, - Minneapolis, Minn.

Chas. E. Holt, - - Duluth, Minn.

O. A. Th. Solem, - Halstad, Minn.

\section{EXECUTIVE COMMITTEE.}

S. M. Owen, - - $\quad$ - $\quad$ - $\quad$ - $\quad$ - Minneapolis, Minn.

S. B. Green, - - - - $\quad$ St. Anthony Park, Minn. Wy. R. Doвbyn, - - - - - - Minneapolis, Minn. O. F. Brand, - - - - - $\quad$ - $\quad$ - Faribault, Minn. J. S. HARris, - - - - - - La Crescel Minn. L. H. WIlcox, - - - - - - Hastings, Minn. C. L. Sмiтн, - - - - - - Minneapolis, Minn.

\section{AUDITING AND PRINTING COMMITTEE.}

L. A. Wilcox.

S. M. OWEN.

S. B. GReEn. 


\title{
LETTER TO THE GOVERNOR.
}

\author{
To His Excellenct, Hon. Knute Nelson, Governor of Minnesota:
}

Dear Sir:-The legislative act of 1893 , basing support for the State Forestry Association, requires an annual report of its doings, together with such other information as it may deem necessary to further advance the interests of forestry.

The Minnesota Board of World's Fair Commissioners liberally provided for an exhibit of our woods at the Columbian Exposition of 1893, in Chicago, I11., and allowed the Association the honor of official representation. The exhibit ranked with the first class, and awarded accordingly. Great interest was manifested in our woods by citizens of other states and nationalities, and earnest inquiries made as to their extensiveness for commercial uses. Soon after the close of the exposition, the commissioners tendered the entire exhibit to the Forestry Association, as state property in trust, and re-erected it in the Main Building on the State Fair Grounds, preserving its original form greatly improved.

During the fiscal year the Association published and distributed 35,000 copies of the Tree Planter's Manual and other forestry pamphlets, besides the ninth edition in the report of the State Agricultural Society. The secretary also prepared the forestry department in the report of the State Horticultural Society, and President Stevens, in the annual of the Farmers' Institute. Under the direction of the World's Fair commissioners, the secretary edited another 32-page pamphlet on forestry, entitled "Minnesota and Its Flora," and distributed the 10,000 copies at the Columbian Exposition. The aggregate of these several pamphlets is 70,000, added to which should be mentioned our other forestry literature issued in The Progressive Age, Farm, Stock and Home and other journals, reaching weekly and semi-monthly hundreds of thousands of readers.

The association expended $\$ 94.70$, of which $\$ 47.75$ were new membership funds, for forest seedlings and seeds, and distributed the same among people calling for them. Most of these plants were evergreens.

The association has now arranged to distribute mail packages of the Jack Oak Acorns to be planted this fall as tests for wind-breaks.

An effort was made to raise evergreens for next year's free distribution, but the dryness of the purchased seeds and the severe drouth brought only failure.

In presenting this summary of work, we respectfully call the attention of your excellency to this report, especially to what relates to the needs of legislation on irrigation, forest reservation, forest zoölogy, forest fires and forest education in our common schools. 


\section{EXPENSE ACCOUNT.}

\section{- 1893 .}

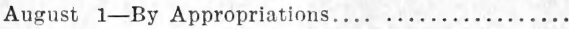

" 7 -Coöperation Printing Co., prtg. Manual..

" 7-The Progressive Age, pamphlets........

25.50

$\$ 1,500.00$

" 19-The Progressive Age, printing and postage.

22.00

23-J. O. Barrett, postage and express.......

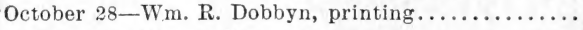

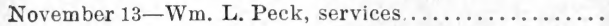

" 25-Wm. R. Dobbyn, serv. and seed expenses..

28-J. O. Barrett, express and postage......

December $15-W m$. R. Dobbyn, publication and distribution forestry literature.............

January 30-J. O. Barrett, labor services and postage.

Fobruary 24-J. O. Barrett, services, ninth edition Manual and expenses..................

" 27-Wm. R. Dobbyn, pub. forestry literature.

March 5-J. O. Barrett, paid for pub. pamphlet....

" 24-J. O. Barrett, seed dist. mise. expenses..

“ $\quad 30-W m$. R. Dobbyn, pub. forestry literature.

May $7-W m$. R. Dobbyn, pub. forestry literature.

" $12-$ Wm. R. Dobbyn, pub. forestry literature.

" $21-$ J. O. Barrett, preparing and dist. lit.... •

" $31-\mathrm{Wm}$. R. Dobbyn, prtg. and dist. lit......

June $33-W m$. R. Dobbyn, prtg. and dist. lit......

July 14-J. O. Barrett, preparing and distributing forestry literature, and postage.......

65.50

50.64

25.00

30.00

55.15

25.00

25.00

8.58

75.45

25.00

25.00

79.01

"25-L. H. Wilcox, expenses as member of Finance Committee............. 12.50

" $30-W m$. R. Dobbyn, pub. and dist. literature.

August 4-J. O. Barrett, stock for tenth edition of Tree Planter's Manual..............

" 14-J. O. Barrett, work on terth edition of

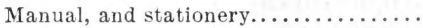

" 14-J. O. Barrett, publishing 10,000 copies tenth edition Manual 1894.......... 275.00

" 14-J. O. Barrett, binding 500 copies tenth edition Manual 1894............. 60.00

$\$ 1,380.67$

" 14 -To balance.................... 119.33

1894

$\$ 1,500.00 \$ 1,500.00$

16-By balance in State Treasury...........

$\$ 119.33$

J. O. Barrett, Secretary.

John H. Stevens, President. 


\section{Indigenous Trees and Shrubs.}

\section{CAPULIFERAE.-OAK FAMILY.}

The oak is one of the most useful trees in the world. Having greater tenacity of fiber, solidity and durability, it is first sought in the construction of bridges, cars, sea vessels, implements of industry and husbandry of every description. It does not produce good seed until it is about six years old, and seldom fruits two successive years. It increases in productiveness with age. It takes five or six years to get a good foothold in the soil, and then it grows rapidly till it has attained the age of thirty or forty years. Some of the oaks have great longevity, extending to upwards of a thousand years.

Prof. Asa Gray classifies thirty-two species of the oak family in the United States. Prof. Warren Upham, in his catalogue of the Flora of Minnesota, mentions fourteen, eight of which are classed as oaks real -quercus.

THE WHITE OAK, Quercus alba.

The white or American oak is common over the middle states, also the Canadas and as far north as Lake Winnipeg where it is rarely over ten or twenty feet. It used to be abundant in our state, and still remains with us, scattered over woodlands, more especially where the transportation does nob warrant cutting. The size varies with the soil and climate. An idea obtains that where it naturally grows the soil is strong. It does not follow, for it plants itself on gravelly and sterile soils, and wherever its acorns can get a foothold. The larger in size and better in fiber are found in deep, rich soils.

It can be readily distinguished from other oak by its leaves which are regular and oblique, divided into oblong, rounded lobes, destitute of points. "Soon after unfolding," says Nuttall, "they are reddish above and white and downy beneath; when fully grown, they are smooth and of a light green on the upper surface and glaucous underneath. In the fall they change to a bright violet color, and form an agreeable contrast with the surrounding foliage which has not yet suffered from the frost." It can also be distinguished by the whiteness of its bark, frequently variegated 
with large black spots; useful for tanning purposes. The acorns of this tree, and nothing is more interesting to inspect, are oval in form, large, sweet, contained in rough, shallow, grayish cups, single or in pairs.

The wood is reddish. It is manufactured into wheels, furniture, car frames, plow beams and handles, bridges, steamers and sail vessels, dock yards, and multitudes of other things that require solidity and durability.

The demand for the wood is so great that ere a quarter of a century has passed, the American oak for commercial purposes will be the same as extinct. How few give the least thought of the oak famine just ahead!

\section{SCARLET OAK, Quercus coccinia.}

The scarlet oak is quite common on the Upper Mississippi, interspersed with other oaks. In favorable localities it is known to grow from three to four feet in diameter and eighty feet in height. Gray bark, its interior reddish; wood also reddish, coarse-grained, open pores, poor timber compared with white or red oak; makes good staves. Its leaves have long footstalks, beautiful green, smooth, shiny on both sides, deep, narrow lobes, which in perspective look like green-bordered bays. After successive frosts in the fall, they turn to a bright red. Acorns. large and somewhat elongated; cups coarse-scaly, covering half or more of the rounded acorns. This tree does well in dry soil, and may be considered as hardy for the prairie.

\section{THE POST OAK, Quercus obtusiloba.}

The Post Oak, known elsewhere as the Box-white Oak and sometimes Iron Oak, is, as a rule, but thinly disseminated over the country. Either by birds or some other method of transportation, its acorns have lodged in the soil regions of the Upper Mississippi, but is infrequent.

Its fructification seldom fails. "The acorns are small, oval and covered for a third of their length with a slightly rugged grayish cup. They are very sweet, and form a delicious food for squirrels and wild turkeys (farther south), hence the tree is sometimes called the Turkey Tree." It rarely exceeds fifteen inches in diameter and forty to fifty feet in height. It has elbow-like branches, disproportionately large summit and thick, grayish white bark. I leaves are thick, grayish, downy beneath, pale and rough above. The wood is yellowish. For staves and posts it takes the lead of all the oaks. Its timber is sometimes confounded with the white oak, which it resembles. Probably has never been well tested on the prairies of Minnesota. Being so tough every way, with judicious treatment it would, no doubt, prove invaluable.

\section{YELLOW CHESTNUT OAK, Quercus prinus acuminata.}

This tree is rare in comparison with many others. It has been found in the southeastern part of Minnesota. Its special retreat is in valleys where the soil is loose, deep and fertile; and there it may attain a height of seventy or eighty feet, and two feet in diameter; the branches trying to hug the trunk as if to protect it from the cold, a habit that perhaps would commend it for the prairie where it can be rightly protected by other 
Its leaves are oblong or lance-like. The acorns are small, set prettily in slightly scaly cups, and are sweeter than those of any other species in the United States. The bark is whitish, sometimes plated. The wood is yellowish. Its pores are irregularly disposed, quite numerous, hence not equal in strength and durability with some of the other oaks.

THE BUR OAK, Quercus macrocapa.

The Bur Oak, known also as the Over-cup or Mossy-cup White Oak, is common throughout the state and country at large. It is found growing in all kinds of soil. According to Bell, its northern limit north of Lake Superior is near the international boundary.

The leaves are larger than any other oak in the United States, sometimes fifteen inches long and eight inches broad, notched near the summit and lance shape; "obovate" (broad end upward), or oblong lyrately pinnatifid (lobed like a lyre) of various shapes, pale or downy beneath, smooth above. Its oval-shaped acorns are larger than those of anyother American species. The cup is thick and rugged, covering about two-thirds of the acorn, hard pointed scales, the upper ones, tapering into bristly points, making a mossy fringed border. Sometimes, however, more especially in compact forests, these flexible filaments are absent, the edge smooth and bent inward.

The fructification of the Bur Oak is not abundant. On sterile soil it is small. On the alluvial bottoms or anyother deep, rich soil, it towers up majestic, sound and full-meated, like the white oak which it there resembles. In such localities its timber is by no means second-handed. In its best estate it grows sixty or more feet high, having tall and far-reaching limbs, laden with dark tufted foliage. Its bark resembles the Corkbark Elm. This hardy oak deserves more credit than it receives, and should be planted more extensively.

JACK OR BEAR OAK, Quercus Banisteri. Nuttall.

The Jack, or Bear Oak, known also as Black Jack, is indigenous to Minnesota, and is very prolific where it gets a foothold, especially in the more barren and sandy sections. It is bushy, often not more than three to four feet high, but sometimes, in favorable localities, will tower up from 15 to 20 or more feet. It grows in clusters, sometimes literally covering acres, forming so dense thickets as to prevent the passage of attle; would, therefore, make a superior wind break, and in winter, is equal to, if not better than, evergreen hedges, for its leaves hang on the limbs, and no wind seems strong enough to remove them until the buds of spring push them out of the way. No tree in Minnesota is more hardy. "It is an excellent tree to plant for shelter belts," says Mr. Hodges, "serving the same purpose in this regard as the evergreens to screen the farms from the cold blasts of winter." It also makes an excellent fuel.

GRAT OAK, Quercus borealis.

It is located on Prairie River, attaining a height of fifty feet and a diameter of ten inches. It bears a close resemblance in foliage to the red 
oak and in its fruit to the scarlet oak. Leaf large and smooth. Acorns middle size, the ends round, cups scaly. Wood, coarse and open, fit only for dry wares, but is strong and durable, employed for the knees of vessels and wheelwright's work. Otherwise it has no special interest to commend it.

SWAMP, SPANISH OR PIN OAK, Quercus palustris.

A tall tree, found in moist places; hugs to the swamps to find protection of other trees; and on the upper Mississippi, in rich soil, towers eighty feet or more with a base of three or four feet in diameter. Its secondary branches are numerous, slender and quite closely intermingled.

Leaves similar to those of the scarlet oak, differing principally in proportions. Acorns, small, round and contained in flat saucer-shaped cups that have short scales.

The bark is adhesive, scarcely cracked; cellular tissue very thick. Wood, coarse; pores, open. When young, its pyramidal shape and elegant foliage recommend it for parks.

RED OAK, Quercus rubra.

The habitat of the Red Oak is in the north where it is cool. If so unlucky as to get into poor soil, it by no means is diminutive, compared with its congeners like situated. Proí. Gray speaks in its praise, so does every other botanist. Large tree; dark gray, smoothish bark; coarse, reddish wood. The pores are often large enough to pass a hair; strong, used for staves and furniture; excellent for dry wares.

Leaves smooth, shiny on both sides, large, deeply laciniated (slashed), roundish at the base, of a dull red in autumn, turning yellow before they fall. Acorns, abundant and large, voraciously devoured by bears and other wild animals; even horses and cows like them, and hogs fatten on them. "Cups, saucer-shape, on a narrow neck, of fine, close scales, very much shorter than the nearly oblong acorn." It is the first of American oaks introduced into Europe. It is found as far north as Saskatchewan and the rocks of Lake Namakeen. Its beauty is unsurpassed.

The author has thus described the native oaks of Minnesota, as reported by Prof. Warren Upham. There are others introduced into some of our parks and lawns, some of these from the eastern continent, and when fully tested as to hardiness, will be sought more extensively; but the mania to look abroad for our trees is not recommendable. We are amply supplied with what are already acclimated, being indigenous.

\section{HOP-HORNBEAN, Ostrya Virginica.}

The American, or Hop-Hornbean, is known also as Iron wood, Lever wood, without other distinctions; common in Minnesota, except close to Lake Superior. It is usually found in cool, shaded, fertile localities. Farther south it sometimes grows twelve or fifteen inches in diameter, and from thirty to forty feet in height, but commonly half that size in our state.

Its leaves are alternate, oval-shaped, taper-pointed, fine-toothed. They are quite birch-like. The flowers appearing with them in the spring, are borne at the extremities of the branches, and the fruit is in clusters like 
hops. The seeds are small, hard, triangular, contained in oval, reddish, inflated bladders, covered with an irritating fine down. The bark in winter is smooth and grayish, detached in strips, finely divided. The wood is purely white, fine grained, heavy, compact. The tree is a very slow grower. It is used mainly for levers by the woodsmen; it can be put to many mechanical uses, such as blocks, mill-cogs, mallets, etc.

Carpinus Americana is the true American Hornbean, also called the blue or water beech. This is a low tree; its trunk furrowed; very hard wood; close gray bark; small leaves, resembling those of the beech; flowers with the leaves in the spring. Quite common in our native woods, growing indifferently as to soil. There is a unique beauty about it. Its white, tough wood recommends it.

\section{THE BEECH, Fagus ferminea.}

Probably not a native beech tree grows in the woods of Minnesota, but it abounds in Eastern Wisconsin under the salutary influence of Lake Michigan. Though not suitable for a pioneer tree, yet it is so valuable and susceptible of surviving in special localities cader right treatment, it is worthy of consideration. It must have moist soil and cool atmosphere. It is not well adapted to our dry prairies, but is to the drained alluvial soils of our river valleys, where they can be insulated by protecting forests.

Seed will have to be procured outside of the state. Be sure and have the northern grown, such as Eastern Wisconsin furnishes. It ripens in October. Soon as possible plant under tree shade, where there is light enough, however, to sprout them healthfully. Thin out the old shading trees gradually, for the young beeches must be acclimated. In three or four years you should have all the near supports removed for the reception of ample light and ventilation.

\section{URTICACEAE.-ELM FAMILY.}

The Elm belongs to the Nettle Family, which, according to Gray, includes thirty-eight or more species and varieties in the United States. Upham mentions thirteen for Minnesota. But we have to deal with trees, not shrubs and grasses. He recognizes but three of the elms, the white, the red, the cork, as indigenous.

\section{WHITE ELM, Ulmus Americana.}

The White or American Elm is magnificent. It ranges over a vast area from New Foundland to Florida and as far west as the eastern foothills of the Rocky Mountains. It adapts itself to different kinds of soil, thriving, with proper treatment, on the prairies central on the continent. It leads all the other elms in hardiness, size, foliage and beauty. It is a fast grower; in deep, rich soil and favorable environment, known to attain from two to three feet or more diameter in half a century.

Evidently there are different types of this tree, two especially marked. In the alluvial soil of the Mississippi and other river valleys of Minnesota, 
some of these species branch out from near the ground, towering up in grand balance, forming large, round heads, the tips of the branches drooping somewhat like the weeping willow. The shade of this species, when the tree is matured, covers a large area, the branches being so freely yet connectedly spread out umbrella shape.

Another conspicuous type is characterized by a single straight trunk, crowned with a smaller and flatter head, and with less shade. It branches higher up from the ground than the former, self-pruned, leaving a long solid trunk, thirty, forty, and even fifty feet, in some cases, free from limbs save now and then abortive branchlets, which in time scale of. As a rule this tree seldom needs any pruning.

Leaves short-stalked, oval, taper pointed. Flowers in April, purplish, clustered. Fruit flat, fringed with a dense down. Easily grown. Matures in June. Then plant it in thin light loam. No tree should be planted more extensively. It belongs to the centuries.

Generally, this elm is hard to split; hence its wood is very useful for wheels, saddle-trees, special kinds of coopering, for keels to small boats, and some other mechanical structures. Quite substantial rope can be made from its macerated bark. When sawed quartering, polished and varnished, it is, in some instances, as beautiful as the black walnut or bird's-eye maple.

\section{SLIPPERY ELM, UTmus fulva.}

Also known as the Red and Môse Elm, and by the American French as the Arme gras. This tree does not grow to the size of the White Elm, nor is it as common. It thrives in a well drained soil, while that variety of the white called the water elm, prefers a low, alluvial soil. In favorable localities of our state it attains fifteen to twenty inches in diameter and from fifty to sixty feet in height. It can be readily distinguished in winter from the white by the buds, which are rounder and larger, and in their early development by being covered by a russet down. Its leaves are also larger, thicker and rougher. "These and the flowers," says Gray, "are sweet scented in drying." The flowers are grouped at the extremity of the young shoots. "Seed in the middle of the orbicular or round oval fruit, far away from the shallow notch." The trunk-bark is brown, heart of a dull red tinge. The wood appears a perfect make-up and very beautiful when well polished and varnished. When exposed to the weather it is of a better quality and more durable than the White Elm. It is valuable for blocks, ox-yokes, etc. "Well known for its mucilaginous, medicinal inner bark." As an ornamental tree it is not as gracefully balanced as the white elm, but for utility it should be extensively planted and carefully preserved in our woodlands and cultivated groves.

CORK ELM, Ulmus racemosa.

The other names for this tree are the White Corky and Rock Elm. For wheelwright, furniture, and other purposes, it is the most valuable of all the elms; its wood is drier, whiter, cleaner rifted, and finer in constituency. It extends north on the higher shores of the upper Mississippi and its 
tributaries; is common in nearly all the woodland counties; but the tree is fast going. In some particulars it resembles the White Elm, but is easily distinguished by its peculiar color and clefts of bark. The lower branches have corky excrescences; young branchlets downy-haired. The bud-scales are fringed with hairs. The leaves have straighter veins than those of the White. Flowers are clustered; two to four together, the stalk of each particular flower in the cluster being arranged along the sides of a general peduncle (flower-stalk). The winged fruit is elliptical and the margin deepiy fringed. This elm is deserving of special attention.

\section{TILIACEAE.-LINDEN FAMILY.}

Tilia Americana is known as Basswood, Linden, Lime Tree, Whitewood. Naturally abundant in the big woods, but largely consumed now; common throughout the native woodlands of the state, "extending north to Basswood Lake on the international boundary," says Winchell. "Its northern limit is just south of Thunder Bay, from which it nearly follows the international line to the Lake of the Woods, and thence extends nearly to Lake Winnipeg and northwest to Fort Ellice." Being found so far north is proof of the hardiness and adaptability to planting in any part of the state. Its best condition obtains in loose, deep and fertilo soil, growing there from 70 to 80 feet high and 3 to 4 feet in diameter. It generally has a straight and uniform trunk and a broad, tufted summit. No tree is better balanced nor more beautiful.

When but a few years old the leaves are remarkably large, sometimes growing fourteen to fifteen inches long and a foot wide, suspended down a petiole (footstalk) about three inches long. On mature trees they are smaller. They are attached alternate, nearly round, heart-shaped at the base. Both sides are quite smooth. The flowers have numerous stamens or fertilizing organs. "Their filaments," says Gray, "cohering "in five clusters, sometimes with a petal-like body in each cluster; others two-celled pistil with a five-celled ovary, having two ovals in each cell, in fruit becoming rather woody globular, one-seeded little nut. * * * Dull, cream-colored, honey-bearing flowers formed in early summer on a nodding axillary peduncle (flower-stalk) which is united to a long and narrow leaflike bract." Blossoms in June.

The seeds are round, like a pea, grayish, ripening in October. When ready to fall they can be beaten down with a pole. After drying a few days, they should be planted in rich soil. They can also be propagated from shoots that spring up around the trunks of the forest tree, by shoveling soil upon them, and in two years they are well rooted. Layering is a successful method.

The wood is white and tender, clean and beautiful whon polished and varnished. It is used for boxes, carriage bodies, chair-seats, and is growing popular even for floors. 
The flowers of the lindens are special favorites for bees, and the honey thence extracted is classed as of the best quality. It pays to raise them for honey alone; but other commercial values are so great we cannot afford to neglect planting extensively our basswood in every part of the state

\title{
OLEACE $A$.-ASH FAMILY.
}

\author{
WHITE ASH, Fraxinus Americana.
}

Common over the state. Frequent on the banks of our rivers and lakes, and on the edges and acclivities of swamps, scattered also on high drained grounds. A fine tree, straight trunk, of ten undivided to a height of forty feet or more. Bark is deeply furrowed on large stalks, checked into small squares, one to three inches in diameter. Leaves, opposite on their stalks, the green color on their upper surfaces, finely contrasting with the white underneath.

The cylindrical seeds are about an inch long, gradually flattening into wings slightly notched on the ends. They grow in bunches four or five inches long. Ripe in October.

In common with all the other ashes, its thriftiness and value are affected by the soil in which it is planted to a remarkable degree. In rich soil its wood is apt to be brittle; is tough and reedy in sandy soil, greatly enhancing its value. When the wood is perfected, it is reddish; sap-wood is white. It is used for carriage shafts, wheel fellies, sledges, wheelbarrows, scythes, and other tool handles, butter boxes and firkins, sieves, wooden bowls, oars, barrels, etc.

Prof. F. L. Budd, of Ames, Iowa, says : "A grove of ten acres thinned to six feet apart, containing 12,000 trees, at twelve years were eight inches in diameter, and thirty-five feet high, the previous thinning paying all expenses of planting and cultivation. Ten feet of the bodies of these trees were worth, for making bent stuff, etc., forty cents each, and the remaining top ten cents, making a total of $\$ 6,000$ as the profit of ten acres in twelve years, or a yearly profit of $\$ 50$ per acre."

J. Jay Smith reports that the leaves and branches of the white ash "are said to be poisonous to serpents and the leaf to cure their bite. An ash leaf rubbed upon the swellings caused by mosquitoes removes the itching and soreness immediately."

RED ASH, F. pubescens.

In the woodland regions it is quite extensive; "velvety shoots and leaf stalks; fruit flattish, two-edged seed-bearing body acute at the base, the edges gradually dilated into lance-linear or oblanceolate wing." Leaves twelve to fifteen inches long. Wood esteemed equal that of the White Ash. 
BLACK ASH, F. sambucifolia.

"Occasionally plentiful throughout the state, excepting, perhaps, southwestward."-Upham. "Its northwestern limit reaches the southern part of Lake Winnipeg, and thence extends southward along the east side of the Red River."-Bell. "Will develop magnificently on ground too wet for most any other timber, except it may be tamarac."---L. B. Hodges. Buds of a deep blue; young shoots a bright green in early spring. No calyx in the fertile flowers. Leaves have peculiar appendages on each side of their base, when first unfolding, but dropping off in a few weeks. In their full estate, they are twelve to fifteen inches long, "composed of three or four pairs of leaflets with an odd one." When bruised they emit an odor like the Elder. Seeds are flat, bunched and winged. Ripen in the fall. Barka duller hue than that of the White Ash, and less deeply furrowed. Ripe wood of a fine texture and brown complexion; tougher and more elastic than the White Ash, but less durable. Growing more and more popular for strong structures and furniture. More than any other species it develops gnarls attached to the body of the tree. These excrescenses have singular undulations, looking sometimes like clusters of little vines arranged in bowers. The wood of such is very beautiful when polished and varnished. The ashes of this tree are rich in potash. Take it all in all it is deserving of special attention.

BLUE ASH, F. quadrangulata.

Rather a rare tree in ourstate, is found on the upper Mississippi, at Rainy Lake and other northern localities favorable to its growth, and there of ten becomes one of the largest trees of the forest. The leaves are from twelve to fifteen inches long. "Square branchlets. * * Ovate veiny leaflets on short stalks, and narrowly oblong fruits." Its wood is the most highly esteemed of all the ash family, and most extensively used where toughness and beauty are required. A blue color, it is said, is extracted from its inner bark; and it is claimed that the milk of its boiled leaves is an unfailing remedy for the bite of the rattlesnake.

GREEN ASH, F. viridis.

The most frequent of all our ashes. Has the properties of the Red Ash, but is a smoother and smaller tree. Leaves vary from six to fifteen inches long. "The seeds of the green ash are frequently mistaken for those of the white ash, and sold as such by dealers. They can be readily distinguished apart, however. The seed of the white ash has a long wing, and the seed pod itself is elongated. The green ash seed has a much shorter wing and the seed pod is not more than half as long as that of the white ash."-Hodges. Ripens in the fall. Though not a large tree, it will double its natural size by cultivation. "A true pioneer of the forests," says Dr. Warner, of Ohio, "soon to be planted on the plains, it spreads naturally into the native grass, and struggles through the prairie herbage that would destroy other trees." 


\section{BETULACEAE.-BIRCH FATILY.}

The natural climate of the birches is in the northern parts of the eastern and western continents. The cold is as natural to them as to the white bear of the Frigid Zone. Below the 43rd degree, north latitude, they dwindle into mediocrity. Michaux avers that there are as many species of the birch found in the United States as in Europe; "and, from myown obs̀ervations on the comparative properties of their wood, the advantage appears to lie wholly on the side of the American species."

J. Jay Smith, translator of Michaux, says the Earl of Huntington calls the birch an amphibious plant, "as it grows on rich or poor, wet or dry, sandy or rocky situations, nor refuses any soil or climate whatever."

Most of the birches ripen their seeds in September or October. The birches follow in the wake of the forest fire, springing up as if by enchantment. In the woodlands of Europe, fifteen pounds of seed is sown upon an acre. A common method there, has been to harrow up the ground fine and mellow, in the late fall, and cover by dragging over it a brushwood drag. Like all other forest seeds and plants, the birches at first need a shading against hot and dry suns. If the design is to sow in an open field, a good way is to mix it with winter rye, and treat as described, making the cereal crop pay on the forest expenses. This method would do on our woodland territory, but is questionable as to success on the wind-swept prairie.

In the extreme northern part of Europe, the wood is used for the manufacture of almost all the implements of husbandry-wheels, bowls, plates, spoons, chairs, etc. In our country it is beginning to be better appreciated than to use it up for fuel. Some of its species, the Canoe Birch especially, has a wavy grain, beautiful for furniture. In Sweden, Norway and Finland much importance is attached to the bark from which is made pans, baskets, sandals and the like. The rustic people there make soles of it, and fix it in the crown of their hats for protection against dampness. The Laplanders use it in making the reindeer skin water-proof. In Russia the bark of large trees is burned in kilns or furnaces and thence an empyreumatic oil is obtained with which a leather is prepared which is highly esteemed for durability. When young and tender the leaves are given to domestic stock, and families use them as a substitute for tea, and dyers employ them in dyeing wool to a yellow luster. In the spring the sap of the birch is copious and is often boiled down to a delicious syrup.

Susceptible to so many practical uses, and being so hardy and pretty, the birch deserves special attention. Speaking of its beauty, "Emerson remarks." says J.Jay Smith, "that no trees are more distinguished for their light and feathery foliage, and the graceful sweep of their limbs, than the birches; no family affords such a variety of aspect." Certainly no tree on our lawns is more attractive than the Weeping Cut-Leaved Birch-a European hybrid.

\section{BLACK BIRCH, Betula cuta.}

This is known as "Mountain Mahogany" in Virginia, and Sweet and Cherry Birch in New England and Canada. It is not very plentiful with 
us. Dr. Bell says Mirnesota is its northwestern limit. It is at its best in deep, loose, cool soil, and there will grow 60 to 70 feet in height and from two to three feet in diameter. It is one of the earliest trees to unfold its buds. The flowers appear along with its leaves which resemble those of the cherry. "The leaves," says Dr.Gray, "are oblong ovate and somewhat heart-shaped, sharply doubly serrate all around." They are dotted with white and so are the smooth young shoots. Bruise them and they emit a sweet odor, and will retain this quality when dried and preserved. It matures its seed about the first of November. The bark is smooth and grayish, much resembling that of the cherry tree. "When freshly cut, the wood," says Michaux, "is of a rosy hue which deepens by exposure to the light. Its grain is fine and close, whence it is susceptiblo of a brilliant polish; it possesses a considerable share of strength." It is sought for tables, bedsteads, panels, arm chairs, etc: It is a rapid grower. Its mahogany-like wood, its beauty of foliage, its odor of flower and leaf recommend it as a central figure in the park and lawn.

\section{YELLOW OR GRAY BIRCH, B. cutea.}

Prof. Upham, quoting Prof. Winchell, says it is "common in the north half of the state and south of Sherburne county, reaching a height of seventy-five feet and diameter of three or four feet; rare in the big woods and southeast of Houston county." Dr. Gray reports the bark of the trunk as "yellowish gray and somewhat silvery, separating in filmy layers." Sometimes the epidermis is rolled backward at the ends, attached only in the middle. Its golden yellow and graceful foliage render it very conspicuous in the woods. Its fruiting catkins are short-oblong, the scales visibly downy under the lens. The seeds beneath the scales are smallwinged, ripening about the first of October. The wood is not as deep shaded as the black birch, but is strong and handsome; makes good oxyokes and frames of sledges. The bark is used in tanning. Take it all in all this tree possesses many merits and is deserving of special favor.

\section{RIVER OR RED BIRCE, B. rubra.}

This species is rarely found away from limpid streams and rivers. In middle age, when about ten inches in diameter, its epidermis is reddish or cinnamon colored. Like that of the Canoe Birch it can be divided into sheets. Ample in summit, thick branches, twigs long, flexible and pendulous. Leaves about three inches long, two broad; whitish beneath, green on the upper surface; edges deeply denticulated, pointed at summit. Seed ripens in June.

The wood is nearly white, both in the sap and heart. Like that of the Juneberry it is marked longitudinally by red vessels intersecting each other in the different directions. Makes good trays. From its twigs stable and street brooms are manufactured. Its saplings are used for hoops to a good advantage. Unlike other birches it enjoys intense heat, but while it adapts itself to sunny elements it thrives in the north when protectingly environed. 


\section{PAPER OR CANOE BIRCH, B. papyracia.}

Often abundant in the north half of the state; is plentiful in Renville county, especially in Birch Coolie; "is found," says Prof. Bell, "along the Assiniboine valley as far west as Qu' Appelle lakes." It likes the declivity of hills and does not refuse the bottoms of alluvial soil.

Its limbs are slender and flexible, or a shiny brown and white dotted, while the body of the tree, especially when young, is as white as the wintry snow which it delights in. It is more papery than the so-called White Birch of less size. The leaves are of middle size, unequally denticulated, ovate, heart-shaped, dull beneath, dark green above; oblong. downy, shortstalked catkins; wings of fruit broad, ripening toward the middle of July.

The sap-wood is perfectly white. When first laid open its heart is a reddish blue, glossy grained; speedily decays when subject to the extremes of dryness and moisture. It makes superior tables. Some sections of it are as beautiful as mahogany, and is much sought for special embellishment. Like Its kin, the White Birch of Europe, its bark is used for various purposes. Before we had tarred paper, it was laid immediately beneath the shingles to the roofs of our houses. Pretty baskets are made of it, and fancy boxes and portfolios. From it the Indians construct berry boxes and sap buckets, and canoes, so light that they are easily transported on the shoulders from one lake or river to another. A most valuable tree this.

Under the order of Betulaceæ, we have the Low Birch or Tag Alder, common in the north half of the state; the Dwarf Birch, on the northern shore of Lake Superior, on the ridge east of the Red river, of ten companionated with the Green or Mountain Alder. Under this head also is our Black Alder, quite extensive in the wooded north, and the rare Smooth Alder in the southeast.

\section{SAPINDACEAE. - MAPLE FAMILY.}

STRIPED MAPLE OR MOOSEWOOD, Acer Pennsylvaniana.

"Common northeastward, extending south to the upper Mississippi and to southwestern Pine county."-Upham. "Rare and local farther south to Lake Pepin."-Miss Manning. It is a small, pretty tree, having, as Prof. Gray describes, "light green bark, striped with dark lines, large thin leaves finely sharply serrate (toothed) all around, and at the end threesharp and very taper-pointed lobes, slender hanging racemes (flower clustered) of rather large green flowers, and fruit with diverging wings." Attractive at all seasons. "One of the earliest trees to feel the approach of spring." Ripens its seed about the first of October.

mountain MAPLE, A. spicatum.

"Common north of Lake Superior and along the international boundary; extends south to Mille Lacs."-Upham. It is also found elsewhere par- 
ticularly southward on the Mississippi bluffs. Grows from twenty to thirty feet high. Has "slightly three-lobed and coarsely toothed leaves, downy beneath, and upright dense racemes of small flowers, followed by small fruits with diverging narrow wings." Its beauty is most conspicuous in autumn when its leaves have "various rich shades of red, with seeds yellowish," then ripening and ready to fall. Growing naturally on highlands, delighting in the cold, it must be hardy enough for our prairies, mixed with large trees for wind-breaks.

SUGAR MAPLE, $A$. saccharinum.

Known also as Hard and Rock Maple. Not indigenous in the western prairie part of the state, but common in our native woods, except near the shore of Lake Superior. "According to Bell," says Prof. Upham, "the northern limit of this tree extends from the lower part of the valley of the Kaministiquia river westward a little to the north of the boundary line to the Lake of the Woods, where it turns south." It is a tree of the north, mostly abounding in the states and Canada between the $43 \mathrm{~d}$ and 49th parallel. It likes to live on the mountain sides, on the crest of hills, in cold, humid valleys, but everywhere demands fertile soil, Will attain seventy to eighty feet and proportional diameter. Its bark is grayish white.

Leaves about five inches broad, varying in length according to age and vigor. They are attached opposite each other on long stalks, palmated (like the hand with outstretched fingers), five-lobed, bright green above, whitish underneath. The first touches of autumnal frost turns them red. "Calys bell-shaped and hairy-fringed."-Gray. "Flowers small, yellowish, suspended by slender, drooping peduncles. Seeds contained in two capsules united at the base and terminated by a membranous wing "-Michaux. Seeds ripen in October, but mature only once in two or three years.

When first cut, the wood is white, but when long exposed to the light assumes a rosy tinge. Grain is close and fine; silken-lustered; strong and heavy; is not durable as the oak; quickly decays in moisture. It makes good axle trees, wheel-spokes, sled runners, chairs, desks, etc.

BIRD'S-EYE MAPLE.

This also is the Hard or Sugar Maple-not common. Its undulations are like those of the Curly Maple; has spots- "bird's eyes"-about half a line in diameter; sometimes contiguous and then apart. Very much esteemed by cabinet makers. The more numerous the spots, the more beautiful and valuable is the wood.

\section{TAPPING TO DEATH.}

The treatment the sugar maples are receiving from resident whites and Indians is unpardonable. Having ax-stabbed them for sugar for the last quarter of a century, the large trees are rotting out, and such may as well be used for fuel, But spare the young growth by keeping out the fires and imprisoning the men and boys who cut them for camp fires.

The Sugar Maple resists the wind well. It can be raised on the prairie from seed planting, especially when amply protected by the ash, willow, 
elm, and box-elder trees. The Black Sugar Maple is a very pretty variety. It prevails more in the southern than the northern part of the state. Its bark is black, specked with white, contrasting prettily with its densely green and tufted foliage.

WHITE MAPLE, A. dasycarpum.

Also called the Soft Sillver and River Maple. Indigenous to nearly every part of the state, but rare in the northwestern portion; abundant on the alluvial bottoms of the upper Mississippi and its tributaries, and on other northeastern waters. It blooms early; flowers greenish; destitute of petals; fruit woolly when young, soon smooth, developing to oval-shaped seeds with great diverging wings. Ripen in June. Trunk low and sta!ky; many limbed; divergent, spacious head, opening well to the sunlight. Its foliage is magnificent. Leaves deeply five-lobed; silvery white and downy beneath; densely green above. Note them as they tremble in the wind, aflame with their brilliant white and green-a life-moving picture of light and shade. Its sap is saccharine, yielding but half the sugar product of the Hard Maple-measure for measure as it flows from the trees. The wood is white and fine-grained, soft and light; serves well in cabinet making, and is growing more and more in favor; makes the best of charcoal. Rightly managed is a success on our prairies, but needs the protection of other trees, for its limbs are apt to split down in our heavy winds. Pruning of this tree should be on its laterals, carefully preserving the central stem.

RED FLOWERING OR 'SWAMP MAPLE, A. rubrum.

Abounding through the east part of the state, about Redwood Falls, in Winona county and White Earth reservation; extends west to Mead-Portage on the Dawson route, north of Lake Superior. It clings to the borders of running streams and not infrequently to the miry swamps, and yet grows on the elevated ground with the oaks and butternuts. It is the earliest to blossom, unfolding about a fortnight before the leaves. The blossoms are a deep red and so are the twigs. Unlike the other maples, they are without stalks to divide from at the extremity of the branches. The eaves are three to five-lobed, whitish underneath, irregular-toothed. Fruit also reddish, slightly spreading wings. When young the bark is smooth, marked with white blotches; when it has attained twenty-five or thirty feet high, the bark becomes brown and chapped. Sugar is manufactured from its sap. The heart of the wood projects into the sappy portions in the form of an irregular star, making it very pretty. The wood in general is harder than that of the White Maple, is finer and closer grained, sus ceptible of a glossy surface. Nothing is more beautiful when polished and varnished. It is used in manufacturing the staves and spokes of spinning wheels, saddle-trees, yokes, shovels, domestic woodenware. In some very old trees the grain is undulated, known as Curly Maple, of ten having varying shades that are very beautiful. The cellular tissue of this maple is a duil red. When boiled it turns to a purplish color; chen apply a solution of sulphate of iron, and it is a dark blue. With alum it is used in dyeing 
black. Its peculiarities command attention, and its augmenting utilities in the manufacturing and chemical arts entitle it to special planting and protection.

ASH-LEA VED MAPLE OR BOX ELDER, Negundo aceroides.

This is one of our reliable pioneer trees. Indigenous to the whole state where our native woods abound, except at the extreme north, but can be propagated there, for it is a success across the boundary line in Manitoba. In the alluvial soils of the upper Mississippi, Otter Tail and some of the other northern rivers, it sometimes attains two to three feet in diameter. It is characterized with green twigs, drooping clusters of small greenish nowers coming out earlier than the leaves. Even when growing in our native woods it tends to a broad head with dense foliage; hence one of our best shade-needing trees. It sprouts largely from the crown of its roots, interlacing among its companions, climbing to the light, and therefore forms a very compact and solid wind-break. This and the ashes and elms belong in the list of the reliable trees of the prairied West. As yet it is not much used in the manufacturing arts. The seeds are encased in long shells, protruding into rudder-like wings. Sugar and syrup of excellent quality can be made from its sap.

\title{
JUGLANDACEAE.-WALNUT FAMILY.
}

\author{
BUTternet, J. cineria.
}

Otherwise called the Oil Nut and White. Walnut. Once common southward; mostly cut off there for lumber, yet quite extensive on the Snake and upper Mississippi rivers and their tributaries. It is a national tree, belonging mainly in the north. It generally branches out at a small height, mostly horizontal, forming a large tufted head in fine balance. When young it resembles the Black Walnut, but they are unlike in maturity-especially in the woods - the Butternut being light in weight; of little strength and reddish in color, while the Black Walnut is heavier, stronger and of a dark color. No panels are prettier than the butternut. It is a very popular wood for furniture and house finishing. Vegetates early in the spring. Each leaf has seven to eight pairs of leaflets with a terminal odd one. They are lance-like, toothed and slightly downy. The barren flowers in single catkins are attached to the shoots of the preceding year; the fertile flowers on shoots of the same spring, and at their extremes. The fruit is commonly single, oily and palatable. The nut itself is hard, oblong, round at the base, pointed at summit; the surface furrowed irregularly and rough. The bark possesses medical properties, regarded as the best of cathartics. The tree is hardy; will do well even on the prairie 
under protection of other trees. Is a rapid grower. Ripens its seeds in the early fall; should be planted just before the ground freezes up for winter.

BLACK WALNUT, J. nigra.

Indigenous in the southern half of the state. But few timber sized trees now left; young trees springing up where they can; some of our southern farmers are wisely planting large orchards of them on the prairie. With protective environments can be made a fair success between the 45 th and 47 th parallel. Leaves about eighteen inches long; number of leaflets about same as the butternut. The set relation of the flowers are the same. Fruit is rounder than that of the butternut; odoriferous, uneven on surface, appears at the extremity of the branches sometimes seven to eight inches in circumference. Husk is thick. Nut is hard, compressed at sides, grooved into deep furrows. Pith is in plates, sweet, agreeable, but not equal to that of the European Walnut. In other respects our American Black Walnut is superior to the European. Seed ripens in the fall. The bark on old trees is deeply furrowed, thick and blackish. "The duramen of the wood is compact and heavy, of a deep violet color surrounded with a white alburnum."-Wood. On exposure to the air the duramen (ripe wood) becomes nearly black, and the alburnum (sap) speedily decays. Very strong and tenacious; does not warp or split when thoroughly seasoned. Admits of a fine polish. The curly walnut is incomparably beautiful. The ripe wood is not liable to be attacked by worms; is used in naval architecture in cabinet work, in musket stocks, etc. The husks of the fruit make a good dye for woolen stuffs. All things considered it is one of our most valuable trees and should be extensively planted.

\section{HICKORIES.}

These belong with the Walnut family. The Shell-bark or Shag-bark Hickory, Caya alba, is indigenous to -Houston, Winona, Filmore, Mower, Freeborn, Olmstead and some other southern counties; seldom found north of these counties, except where specially planted.

The bark on mature trunks is very shaggy, having rough strips. Like that of the Yellow Birch the narrow plates bend outward at the ends, and adhere in the middle. Amid the shade of other trees the trunk is destitute of branches for three-quarters of its length, and nearly uniform in size. Will grow eighty to ninety feet high and yet be not over two feet in diameter. The fruit ripens in the early part of October. Late fall planting is the more successful way of management. It is round, divided into four seams which readily open at maturity. The nut in this quartodivisional epicarp is comparatively small, having four angles corresponding with the divisions of the thick husk. The kernel is sweeter than any of the American Walnuts except the Pecan-nut. The Shell-bark hickory nuts bring a good price in the market. Like that of all the other hickories, the wood is elastic, strong and tenacious. Has fine rift. It is used for the keels of vessels, hoops, whip-stalks, ax-handles,etc. The tree endures the most intense cold. Why is it not more largely planted? 


\section{OUR OTHER IIICKORIES.}

In our Big Woods, extending north to Snake river, is the Pig-nut or Broom Hickory, C. porcena. (Nutt.) Juglans Glabra. (Willd.) It grows to a magnificent tree. Its wood is reputed to be the strongest and most tenacious of all our hickories. We have also the Bitter-nut, C. amara, more extensive than the former; found on the tributaries of the St. Croix, St. Louis and along the water courses of the upper Mississippi. The woodmen work up its wood into various tools for lumbering and farming operations. Their nuts are inferior to the Shell-bark. Though all our hickories are liable to be worm-eaten and easily decay, they are valuable trees, hardy, and should have a deserving place in our forestry work.

\section{SALICACEAE.-WILLOW FAMILY.}

Prof. J.H. Winchell in his Goological report of 18s3, as compiled by Prof. Warren Upham, enumerates fifteen species of native willows registered for Minnesota. Since then others have doubtless been discovered. We have four as here given that grow to trees. Nearly all our willows naturally grow in humid situations, along our water shores where they serve the useful purpose of preventing the erosion and waste of the soil. The bark of most of them contains a medical property about as effectual in intermittent fevers as the Peruvian bark. Botanists find the willow family as among the most difficult to discriminate. The distinction obtains principally in the variability of their stamens, leaf appearances and seed vessels. Their flowers are generally diœcious, that is, a class of plants whose sex-flowers are ou two different individuals, as opposed to monæcia, with two sorts of llowers on different parts of the same plant. Their seeds, developed in catkins, are very numerous; bence the willows multiply very rapidly.

\section{BLACK WILLow, Salix nigra.}

A river tree, growing thirty or more feet high; usually divides into large limbs at a short distance up the trunk, Leaves long and narrow. A decoction of the roots is pronounced a good purifier of the blood.

The Myrtle Willow myrtiliodes, has its merits, rare southward, frequent northward, even north of Lake Superior. A good protection against Polar winds.

Long-Leaved Willow, $S$. longifolio. There seems to be some confusion among botanists as to the identity of this willow. Gray mentions it as "a low shrub or a low tree." Nuttall, dating from his observations in Oregon, speaks of it as a large tree: "No willow on the American continent presents remarkable and splendid an appearance." It has a very different aspect from this in Minnesota, if indeed it is the same species. It is our Sand-bar willow, common throughout the state. 
ALMOND-LEAVED WILLOW, S. amygloides.

Abounds in the Red River Valley and thence eastward. It attains a tree-like size, peculiarly attractive. Prof. M. B. Webb, in Wheeler's reports of surveys west of One Hundredth Meridian, thus credits it: "The broad leaves, being supported by long and slender petioles, are moved by the slightest breeze, displaying in rapid, fluttering succession their conspicuous white under surfaces, thus producing an effect in striking contrast with the changeless, soft light reflected from masses of the foliage of the S. nigra when swayed gently by the wind."

WHITE WILLOW, S. alba.

Originally from Europe; much cultivated; is very valuable on the prairie for shade-and protection from the wind; hardy and reliable; grows rapidly; yields good fuel; pays well to raise it. Propagated from seeds or cuttings.

\section{OTHER VALUABLE SORTS.}

Among our weeping willows recommended for ornamental purposes, are the Kilmarnock and American.

Willows from Russia and other parts of Europe are introduced, some of them really valuable.

J. L. Budd, L. R. Moyer, Dewain Cook, G. W. Fuller, S. B. Green, and other foresters speak in high praise of the Laurel-Leaved (Salix laurifolia). The salix fragilis, a cutifolia and rosmarinifolia also have special merits.

\section{POPLARS.}

The name Poplar to this tribe of trees was suggested from the historic fact that, "in ancient times, the public places of Rome were decorated with rows of Poplar; whence it came to be called arbor populi, as to being a tree peculiarly appropriated to the people.

AMERICAN POPLAR OR ASPEN, Populus tremuloides.

Abounds especially northward. This small tree blossoms the latter part of April, appearing ten to twelve days before the leaves. The catkins, springing from the extremity of the branches, have silky plumes on them. Leaves are about two inches broad, narrow at the summit, dark green in color; in the spring red-veined; on young shoots large, heartshaped and pointed; on older stocks becomes round, irregular toothed. Having such shapes, and suspended on long petioles, they tremble in the gentlest breeze. 


\section{LARGE ASPEN, $P$. grandidentata.}

Less common than the preceding, but a larger tree. Has a straight trunk, smooth greenish bark, rarely cracked: branches scattered and few, foliaged at their extremities. Leaves nearly round, smooth on both sides and bordered with large teeth. Catkins about six inches long, appearing in the infancy of the leaves, then thickly coated with down.

The two aspens bere mentioned, vast in quantity in the northern woodlands are not utilized with the spruces for wood pulp for paper-making, etc., and with the other poplars are manufactured in to boxes.

\section{BALSAMIC POPLAR, TACAMAHAC, $P$. balsamifera.}

Common in the northern woods. A middle sized tree; "has round or scarcely angled branchlets, very glutinous and pleasantly balsamic strong scented bud-scales, and ovate, or lanceolate gradually tapering leaves." Gray.

The hardiest of the poplars; not so preity as the other species. It extends far into the north. The greater part of the drift-wood is this poplar found on the shores of the Arctic ocean. "Pallas states," says the translator of Michaux, "that the grouse and other birds of that family that feed on the buds of this Poplar during winter, have their flesh imbued with a grateful balsaimic flavor."

BALM OF GILEAD, P. balsamifera, var. candicans.

Frequent northward, sometimes scattered but of tener in groups. Among the environs of the upper Mississippi, it becomes a magnificent tree. Orie such was found on the St. Louis waters, so stated to the writer by a reliable explorer, growing sixfeet in diameter and not less than a hundred feet high. It is very hardy, adapting itself to any soil.

Trunk smooth-rifted, greenish bark, dark green foliage, tufted; branches irregular. Leaves three times larger than the preceding, and heart-shaped. The tree is literally saturated with water; wood requires a long time to season. Roots spread inveterately. Agreeable when budding, but when the sticky buds fall off, the tree is a nuisance in a lawn. The balsamic property is healthy.

\section{LOMBARDY POPIAR, $P$. dilatata.}

"Stiff wiry tree, with closely oppressed branches, and small broadly triangular pointed leaves formerly much planted from the Old World." Not reliable.

WHite OR SILVER LEAF POPLAR, $P$, alba.

European originally, now growing spontaneous. Is a fast grower and massive. "Spreading branches, roundish, slightly heart-shaped, wavytoothed or lobed leaves, soon green above, very cottony beneath. "-Gray. One of our best is the Norway Poplar. Laurel-Leaved and other European species, are valuable. 


\section{COTTONWOOD, $P$. monilifera.}

We have two varieties of the cottonwood, the White and the Yellow, the latter having the better gift; both equally hardy. A very rapid grower to massive size and shade, it formerly ranked as first choice for prairie planting, but it is classed now on the descending scale, for our rainfall and moisture are not equal to its monopolistic demand. On alluvial and other moist soils it is a fine success.

Catkins or tassels are long, flexible, pendulous. Seeds enveloped in white plumy cotton; buds resinous, aromatic and agreeable. When the seeds are ripe, in June, the winds bear their cottony down in all directions, lodging where they can. M. De Foucault, a French botanist, correctly says: "The leaves are deltoid, or trowel-shaped, approaching to cardiform (heart-shaped), always longer than they are broad, glabrous, smooth, having no hairs and unequally toothed; the petioles are compressed and of a yellowish green, and two glands of the same color as the base; the branches are angular, and the angles form whitish lines which persist even in the adult age of the tree."

Like the other leading poplars the wood of the cottonwood is growing in demand, and as a tree will never cease to be in public favor. Propagated from cuttings, and so with all the poplars.

\section{CONIFERAE.-PINE FAMILY.}

What distinguishes the pines from other families is the homogeneity of their fibres (no ducts), their needle or awl-shaped leaves, their scaly catkins or woody cones, their resinous juices. They will grow on most of our drained soils. Not being tap-rooted, strictly speaking, they do not necessarily require deep soil. As their leaves are small, they do not evaporate moisture very rapidly, as do some of the deciduous trees; hence will survive on dry soils where some other trees will perish. They need to be in masses for mutual protection, where exposed to high winds. Propagated from seeds, maturing in autumn. The pine families excel all others in practical values.

\section{JACK PINE, Pinus Banksiana.}

Known also as Black, Gray and Norway Scrub Pine: Extends farther north than any other American Pine, even to Hudson Bay, where it grows but about three feet high. It abounds in the sandy and barren regions of northern Minnesota. In some localities they form very thick woods, unsupported by other trees, save here and there a red pine. A coarse-grained tree, very resinous, excellent fuel; seldom cut for lumber; makes secondclass railroad ties. Ordinarily not a large tree. Flowers in April and May. Branches long, fexible and spreading. Leaves an inch long; cones 
in pairs usually, adhering closely to the branches, like so many horns. Seeds remain in their scaly covers two or three years before dropping out.

NORWAY OR RED PINE, $P$. resinosa.

Specially northern, sometimes scattered, but mostly in groups. A spiring tree, straight trunk, towering up 40 to 50 feet or more to where the limbs ramify. Excellent for piles, wharves, bridge piers, masts, etc. Our lumbermen distinguish two varieties-the Hard, or Pig-Iron Norway, of thick sap and often so hard as to turn the edges of an ax, and the Red-Barked or Timber Norway, with less sap and softer ripewood, and its bark more in plates. Valuable as a lumber tree for special purposes. Leaves a dark green, five or six inches long, united in pairs at the extremity of the branches. Female flowers bluish, cones thornless, about two inches long, round at base, pointed at summit. Sheds the seeds the first year. This beautiful tree is hardy and vigorous. Recommendable for farm and lawn.

WHITE PINE, P. strobus.

The white pines are our principal lumbering trees, the largest and most useful, growing of ten from 80 to 125 , and, rarely, 150 feet high, and from three to six feet in diameter. The elevated and broken region north of latitude 46 degrees, and east of the meridian of the outlet of Red Lake, including an area of 21,000 square miles, is the pine lumber territory of Minnesota. The principal pine forests stretch in a broad belt in this great district, nearly north of said parallel. Lumbermen mention two varieties of this species, the Pumpkin Pine, more yellow in ripewood, and the Sapling pine, of thicker sap and whiter ripewood. The saplings are far the more numerous. Leaves five-fold, four inches long, slender, of a bluish green, delicute and beautiful. Cones long, cylindrical, pendant longer than the leaves. Seeds thin shelled and winged, usually dropping out in October. The preservation of this and the Red Pine species from the hands of the spoiler, is a matter of practical consideration. It is indeed sad to contemplate its extinction from our native woodlands, a fatality sure to befall us unless the government hastens to prevent it.

BLACK DOUBLE SPRUCE, Picea nigra.

Common in the northeast woodlands, mostly found in the swamps, and there stunted and forbidding, and of little use, save as a shield with the mosses against undue evaporation of water there conserved. In favorable localities will grow to a magnificent tree, seventy feet or more high. Its wood is white, light, strong and elastic; makes good spars and knees of vessels. When free from knots is used for sounding boards to musical instruments. From the bark of the young branches is made the spruce beer. The Black Spruce attains its best condition in humid, deep soil, covered with thick mosses. It is pyramidal in form, and very pretty. Leaves a dark green, firm and numerous. Flowers appear at the extremities of the smallest branches; small, reddish, oval cones; winged seeds, ripening in tìe late fall. 


\section{WHITE OR SINGLE SPRUCE, $P$. alba.}

Common, yet scattered northward; grows on drained soils; sometimes attains to two or three feet in diameter, spiring up majestically in a clean tapering trunk, handsomely tufted in a pyramidal form. Flowers in May; needle-like leaves, about half an inch long, covering all sides of the branches; cones small and pretty; scales loose and thin; seeds fall out the first of the winter. A tree of longevity and one of the hardiest of the conifers. It differs from the Black Spruce in that its leaves are less numerous, longer and more pointed, and their color paler; being a bluish green, like those of the White Pine. The seeds are smaller than those of the Black, but the cones are more elongated; and the bark is lighter colored. When macerated in water, the fibres of the roots, like those of the Larch, are flexible and tough, used by Indians to stitch together their birch bark canoes. A tree of special value, which, with the Black Spruce and poplars, is used for wood pulp. Belongs with the "survival of the fittest."

\section{HEMLOCK SPRUCE OR HEMLOCK, Tsuga Canadensis.}

Scarce; a few, it is said, are growing on the St. Louis waters and upper Mississippi in Itaska county. Is pretty when young, grand in maturity? Wood of old trees is shaky; used for roof boards, studding, etc.

BALSAM FIr, Abies balsamea.

A small northern tree, found mainly in groups. In our wild woodlands is apt to be heart-rotted and hollow, but not so when planted in good soil. Handsome when young, pyramidal and graceful. Leaves narrow and flat; bright green above, white beneath. Cones cylindrical. Wood makes excellent butter firkins and the like. A popular tree for the lawn. Blisters form on the smooth bark containing an agreeable balm, used considerably in certain stages of pulmonary diseases.

\section{AMERICAN OR BLACK LARCH, Larix Americana.}

This tree, known also as Tamarac and Hacmatac, is common in most all our swamp lands; grows naturally also on drier hard ground. A magnificent tree, straight, slender trunk, sometimes 60, 80 and even 100 feet in height, two to three feet in diameter. Branches near the summit; bark smooth as if polished; leaves flexible, in bunches, shed in the fall; renewed in the spring. Male and female flowers separate on same tree, as with the pines.

Wood very strong and durable. Largely used for knees to vessels in the East. Constitutes first-class railroad ties, surpassed only by the white oak. Preference obtains for the European species, but it is questionable whether, in all instances, the American is not better for America. A most valuable tree is our larch, but wofully neglected to be devoured by our forest fires. The nursery sort grown from seeds will do well in our cultivated ravines and fiells. 
AMERICAN ARBOR VITE, Thuya accidentalis.

The Arbor Vitæ, or White Cedar, belongs mainly to our almost im. penetrable swamps of the North, there forming a perfect net-work of roots that, with the mosses, cover every knoll and rock and rotten log. Grows also on drained, moist soils, and there of the best qualities. Its aromatic wood is light and durable; used for shingles, telegraph poles, posts, street paving, pails, tubs, churns, etc.; when well seasoned best of lampblack. Precious little care is bestowed upon its preservation. For lawns, screens and hedges nothing excels it. Its foliage is a perpetual evergreen.

RED CEDAR, OR COMMON JUNIPER, Juniperus communis.

Indigenous throughout the wooded portions of the state, but not frequent. The variety alpina is found on the north shore of Lake Superior. A shrub tree six to eight feet high, growing in dry woods and hills, often forming a slender pyramid. This and the Yew (Ground Hemlock) growing in the same region, are indeed desirable; also the Red Cedar, or Red Savin or Sabina, var procumbens, trailing over the rocky banks and grounds, along our northern borders. It has scale-shaped, acute leaves, "the fruit nodding on the short peduncle-like recurved branchlets." Is hardy and hedgy.

\section{RED CEDAR TREE, J. Virginiana.}

Indigenous to the greater part of the state, most frequent in the southeast; "rare near the west side and north of Lake Superior. Found scantily in exposed situations, as on the bluffs or shores of rivers and lakes, growing to be ten to twenty-five feet high."-Upham. Foliage evergreen, subdivided numerously, composed of tiny sharp scales enclosed in one another. When bruised, emits a resinous, aromatic odor. "Flowers inconspicuous, the staminate in oblong, terminal aments; the fertile on separate trees, producing small, bluish berries, covered with a white powder."Wood. Seeds mature in the early fall.

The wood is a bright red tint; sap perfectly white; odorous, compact, fine-grained, stronger than the White Cedar. Highly esteemed for cabinet work and manufacture of pencils; growing scarcer and higher priced. So hardy and branchy it shculd have special attention paid it in prairie forestry.

\section{NON-INDIGENOUS EVERGREENS.}

The Norway Spruce, Scoteh and Austrian Pine (European) are popular trees in Minnesota, and yet, all qualities considered, they do not excel our native ones. The Colorado Blue Spruce, Picea pungeus, and Bull Pine, Pinus ponderosa, have promise of success for prairie planting.

THE QUESTION TO SOLVE.

Our valuable pines, our spruces, our larches, our cedars, that have broughtus woalth and comfort immeasurable, serving as a primal factor of 
our very civilization-shall they be preserved with our hardwoods for perpetual forests to bless our successors? The question is pressing; and our legislature must solve it.

\section{RED BUD OR JUDAS TREE, Circis Canadensis.}

Rare locally in southeastern counties; planted in some of our lawns. Is small and handsome. Flowers numerous, colored like peach blossoms; ripening into pods scarcely stalked in the calyx. Rounded leaves and somewhat pointed.

\section{KENTUCKY COFFEe TREe, Gymnocladus Canadensis.}

Rarely indigenous in Houston, Winona, Scott, Blue Earth, Nícollet, Brown and other southern counties. In our state seldom exceeds six or eight inches in diameter; farther south grows twice as large and fifty to sixty feet high. Straight trunk, tufted foliage. Wood very hard, straightgrained, of a rosy hue. On young, healthy trees, the leaves, doubly compound, are three feet long and about twenty inches wide. Leaflets, opposite, are oval shape and pointed; of a dull green.

Large flowers, diccious, pods bowed, reddish brown, hard gray seed. Plant in the fall just after they ripen. Beautiful foliage; wood very valuable for cabinet work. A tree this of special merits.

WILD BLACK CHERRY, Prunus scrotina.

Common except in the far north. Grows to good size in rich soil. Trunk regular; bark block-like and rough, bitter and aromatic-medicinal. Wood dull light red tint, deepening with age; fibre brilliant, compact, fine-grained, seldom warps when well seasoned; much valued by the cabinet maker, preferable even to the Black Walnut. Leaves are smooth, lance-oblong, taper-pointed, having incurved short callous teeth. Flowers spiked, white, beautiful. Fruit the size of a large pea, purplish black, vinous-bitter, yet quite palatable. Nice for birds, saving our more valuable crops. A tree of beauty and very valuable for furniture. Is hardy but needs support of other trees. Seeds ripen in autumn, and should then be planted.

LOCUST TREe, P. senda acacia.

This adventive tree belongs now with us. Light foliage; each leaf is composed of opposite leaflets from eight to twelve with an odd one at the summit; thin and so smooth dust cannot adhere to them. Flowers hang in pendulous bunches clearly white and very fragrant. Five or six black or brown seeds ripen in flat pods about three inches long, which often hang on till late in the winter. Bark very thick and furrowed. Young trees are armed with thorns disappearing in maturity. In the main the wood has a greenish-yellow, streaked with brown veins; hard, compact, strong; endurable under all circumstances. Best qualities have a red heart. Owing to difference in color of the heart, arising probably from soil conditions, the tree is variously known as Red, Green, White and Black Locust. Very 
beautiful when polished. Is a good substitute for the Box-wood; is often manufactured into dorrestic ware, such as sugar-bowls salt-cellars, spoons, etc. It is not recommendable as an ornamental tree to stand alone. Its branches break easy in the wind; its limbs are illy balanced and shade scanty. All over the United States and the Canadas, it is attacked by a worm that eats into the heart and kills the tree prematurely. When thus bored into and wind-disheveled, it presents a most forbidding aspect. If hunters would spare the wookpeckers we could have the locusts in our forests and planted groves for marketable purposes. No species of trees furnish so valuable posts and railroad ties, when not worm-eaten. The Rose Flowering, Yellow-wood, Sweet and Water Locusts have special merits.

\section{HARDY SHRUBS.}

In his twelfth annual report of the Geological and Natural History Survey of Minnesota, Prof. Winchell, through Prof. Upham, acting as assistant, says, p. 183: "Of the 412 species in Sargent's Catalogue of the Forest Trees of North America (north of Mexico), 81 occur indigenously in Minnesota; but eight of these, though becoming trees in some portions of the United States, do not here attain a tree-like size or habit of growth, while forty-eight become large trees, at least forty to fifty feet high. Besides these, about 125 indigenous shrubs belong to this flora, making its whole number of wooded plants about 206.

In the same catalogue of the total number of plants in Minnesota, Prof. Winchell enumerates 1,650 , one-twelfth of which consists of introduced species, belonging to 557 genera, and representing 118 families or orders. Since then Conway MacMillan, Professor of Botany, in the University, adding to the list by virtue of further research, estimates that we have 1,750 seed-producing plants, 75 species and varieties of ferns, club mosses and allied ferns, 700 mosses and liverworts, 2,500 fungi, 800 algæ, 250 lichens. The work of collection is by no means finished. There are numerous species and varieties, new to science, waiting discovery "in neglected nooks, in marsh, in dense woods, cool ravines, on cliffs and hills, in streams and lakes."

The author of this compilation has included in his descriptive enumeration of indigenous trees (real) some of our large shrubs referred to by Prof. Upham. As there are other shrubs of smaller sizes which are necessary to complete genuine forestry, serving as protective supports to our large trees, some of them are here summarily mentioned as hardy and reliable. Without shrubs of some sort mixed in with our trees, we cannot reasonably expect success in our cold and hot windy climate. They should be planted and fostered in our forest clumps and wind-breaks; and as a sonrce of juxury and profit, it is well to select such as bear berries for the market 
and table. These especially are here catalogued. Certain introduced species are included, but only such as have been tested as adaptable to our climate, some of which are recommended by Prof. Green, of our Experiment Station at St. Anthony Park.

\section{HAZEL NUT, Camylus Americana and rastrata.}

Common in the woodlands. The latter is so hardy as to grow on the north of Lake Superior, where the shrub is weighty with fruit.

\section{HIGH BUSH CRANBERRY, Viburnum opulus.}

Native, vigorous and hardy; grows from four to ten feet high; white flowers in June; clusters of yellow and red edible fruit hanging on into the winter. Grown from seed, cuttings or layers.

BURNING BUSH, Enonymus roperpureno.

A tall shrub indigenous to the southern part of the state, extending north into Anoka, Kandiyohi, Clay and other counties on like parallel. Can be safely planted all over the state except in the extreme north. Contrasting with other shrubs, it is desirable for the lawn. Would serve a valuable purpose in our planted groves and underbreak as brushwood protection to our principal trees, and so the Trailing Strawberry Bush which has long trailing branches.

\section{COMMON BARBERRY, Berbis vulgaris.}

It is strong, prickly, suitable for a small, loose hedge; yellow flowers in June; red fruit; very hardy. Other varieties are the Purple-Leaved and Thunborg's barberry. Grown from seeds that ripen in autumn.

SIBERIAN PEA TREE, Caragana arborescens.

Close, neat, locust-like leaves, and bright yellow, pea-shaped flowers; pretty; one of the hardiest. Grown from seeds that ripen in autumn.

\section{NINE BARK, Physocarpus opilifolius.}

Grows strong, six to ten feet high; clustered flowers in late June; makes good screens. Grows from cuttings and seed. The Golden Spirœe excels for its graceful form and golden green leaves.

\section{ALDER LEAVED BUCKTHONN, Ramnus anifolius}

Is a shrub-tree, rare southward in Minnesota, common northward, found largely in the St. Croix river regions, and the beach of Lake Superior and Lake of the Woods. Leaves oval, acute at summit, their margins pointing forward like saw teeth. Flowers greenish, axillary, in small. clusters, early summer. Fruit three-seeded, mawkish in taste.

\section{HEDGE PLANTS.}

Common Buckthorn, $R$. catharticus, introduced, has thorny branchlets, hardy; a good hedge plant; three to four seeded fruit. Juice of the berries a strong cathartic; barl. an emetic quality. Juice of the unripe berries 
with alum gives a yellow dye; when this mixture is concentrated it gives a sap-green used by painters. Withal a valuable shrub to plant.

JERSEY TEA.

Buckthorn. The species known as Red Root, Jersey Tea, Ceanothus Americanus, is worthy of a place in our forestry work. It is quite common throughout the state, except far northward. A shrub ranging from twenty-five to thirty feet high; roots red, mossy, gnarly; a nuisance to the plow. Flowers, summer, crowded in a dense slender peduncled (flower stalked) cluster. The leaves deciduous, ovate, finely-toothed downy beneath, three-ribbed and veiny; sometimes used as a substitute for tea. So gnarly rooted, adapted to dry grounds, it can no doubt serve an admirable purposeas a pioneer in regenerating wild and barren localities, preparatory to the planting of larger and more advanced trees.

\section{ENGLISH BUCKTHORN, Rhamnus catharticus.}

A popular hedge plant of Europe and the eastern states; bears close pruning without injury; robust, pretty, white flowers in June; black berries, hardy even in very severe localities. Seeds ripen in autumn.

PRICKLy ASH, Zanthoxylum Americana.

Common, perfectly hardy; makes an impenetrable hedge. Autumn seeds.

\section{BUFFALO BERRY, Shepherdia argentea.}

Give it a proper place and it will grow from ten to fifteen feet high; found along the water courses of Dakota and Montana; bears imperfect flowers before the leaves appear; leaves are silvery and pretty; difficult to secure pistillate plants, hence must have fertilization; fruit red, having one quite large seed; acid, makes a good jelly or sauce; hardy, and is used for hedges. Grows from seed.

\section{RUSSIAN MIULBERRY.}

The Russian seems to take the lead of the mulberries in Minnesota. Useful for shelter and wood. Standing alone, it is handsome. Makes a solid hedge. Its fruit has an aromatic odor, sub-acid, sweetish. Thornshrubs of the Cratægus family, such as the White, with its rigid thorns and crimson fruit; the Black (American) and Hawthorn (English), are well fitted for hedges and the forest borders.

\section{RED AND Yellow PIdU, Prunus Americana.}

Select, blossoming in April and May and fruiting in July and August. Let them occupy the sunny niches of the woods, protected and protective, yielding their delicious plums.

\section{THE UNDERBRUSH.}

In the planted forest place the dogwood, the native hollies, red bird cherries, the choke cherries, the June berries the wild raspberries and blackberries, currants, dewberries, sand-cherries, gooseberries, elders and wild dwarf roses, along the borders with the thorns, and grow in there 
the mint faruily, the boxberry, the wintergreen, the genseng and whatever else is safely medicinal and esculent. The mosses will assert their rights to a place there. They will grow spontaneous where there is shade enough and moisture and decaying wood on which they feed. Conditions obtaining, introduce all possible varieties of mosses and ferns that are adaptable to the situation. The practical idea is to naturalize our forestal art for beauty as well as utility.

VINES AND CLIMBING SHRUBS.

As vines are constituents of a real and successful forest, some of our more conspicuous and hardy are here mentioned.

American Ivy, Ampilopsis quinquefolia. Native, strong, hardy; beàutful, bright crimson foliage in autumn. Surpasses all for covering porches, unsightly fences and decayed trees. Grown from cuttings, layers and seeds.

Bitter Sweet, Celastrus scandens. Hardy, clean, conspicuous and pretty when covered with its orange-colored seed pods. Grown from seed or layers.

Virgin's Bower, Clematis Viryiniana. Native, healthy and strong, bearing a profusion of small, white, fragrant flowers in August. Makes a beautiful contrast with the ivy just mentioned. Grown from seed or layers. The C. viticella is equally satisfactory, having large blue or purple flowers, producing them all summer.

Moonseed, Menisperum canadense. Slender and pretty, large leaves; succeed well in partial shade; grown from seed.

Wild Grape, Vitis riparia. Coarse but beautiful, covering dead trees or any unsightly object. Hardy anywhere; fragrant flowers. Excellent stock for grafting on the domesticated grapes. Grown from cuttings or layers. 


\section{How to Manage Forest Seeds, Seedlings and Cuttings.}

Most of our prairie farms are tillable. For this reason they specially need wind-breaks. Then why not copy nature's art here? The wind-breaks could be economically placed in separate groups and clusters and curves, leaving wide spaces between them for fields and orchards, thus breaking the winds from all directions, and yet leaving the best possible ventilation, so that none of the crops will be crowded or shaded. There is such a thing as blending the beautiful with the utilitarian, making the farm a perpetual satisfaction.

THE SQUARE STYLE.

If farmers will persist in having the square style of forestation, surmising that they thus abridge the forest acreage and better arrange their agricultural grounds, there should be the same studied effort to adapt the species of trees to the situation and where they can best perform their functions. The hardiest and most flexible should be planted on the outside to cut the prevailing winds, and these, on our prairies, are generally from the west and south in the seasons of plant growth. It is not wise to leave the south open as some do, as our hottest wind-waves beat in from that direction, like so many blistering simoons. The denser wind-breaks are, therefore, needed on these two sides, also protection on the north and east, but not to the same special extent.

\section{WINDROWS AND SNOW-DRIFTS.}

On the outside plant two rows of white willows not over one foot apart. As it is desirable to prevent snow-drifting on your premises, leave an open space next the willows, where it will naturally lodge, of twenty or thirty feet. Beginning on the hither side of the snow-lane, plant, four feet apart, several rows of ash; then rows of box-elder, cottonwoods, maples, elms, hackberries, oaks, buttærnuts, and line the inside of the "deciduous wall" with white spruces, arbor vitæs, pines, and other evergreens, not right up under the shade, but thirty or forty feet distant-two, three, yes, four rows of them, so placed that the trees in each row will form perfect triangles with each other, thus the better protecting each other. In a few years their branches will begin to interlock in solid arches. Such a forest will resist any wind and will protect the fields and orchards in the leeward safe from all harm. In less even than a decade that farm will be worth ten times more than it was at first, and that forest has made it 
so. What can possibly enhance farm values like an ample supply of fuel close at hand, and a living and perpetual shield to the crops and stock and inmates of the home?

\section{SELECTION OF SEEDS.}

To insure success, the seeds must be of the best quality. Avoid the first installment that falls, for insects may have caused unhealthy ripening. Seeds from stunted, malformed or dwarfish trees may be morbid in makeup; avoid them, also seeds from trees enfeebled by extreme age or other debilitating causes. The trees should be middle-aged, and a little separated from others where they have the full benefit of the sun and air which gives a full head and a healthy condition.

TIME TO GATHER.

Seeds should be gathered when the weather is dry, and when they fall to the ground as if heavy-in showers at the beating or shaking of the trees.

\section{I'RESERVATION OF SEEDS.}

It is difficult to determine the exact condition by which all kinds of seeds may be preserved. By experience it has been proved that seeds will not germinate if placed in vacuo or in an unbalanced atmosphere, such as hydrogen, nitrogen or carbonic acid. Judging from the duration of seeds buried in the earth, and from other circumstances, the essential conditions are: 1, uniform temperature; 2, moderate dryness; 3 , exclusion of light.

\section{ART OF DRYING.}

When gathered, the seeds should be immediately spread in thin layers in a dry, airy place, raking occasionally until the dampness has evaporated. There is such a difference in the conditions of species as to tendencies to sprout, to heat, to rot, to perish by desiccation, or to mould, no one set rule seems to be always applicable. The seedsman must be a close student of nature's art of preservation, and act according to conditions and circumstances. But we have some guides, which are herein mentioned, safe to follow. When properly dried so as not to heat, put them into sacks and keep them from drying-out by mixing with sand, hung up in airy sheiter.

\section{BOX-ELDER AND ASH SEEDS.}

As the box-elder and ash are our pioneer trees, special attention is called to the management of their seeds, ripening in autumn. They are liable to be injured by the drying art, hence the safer way, also, for the sugar maple, is to plant them in the late fall, and more seeds will thus sprout. If the spring planting is preferred, the better to escape the early frosts, soak in a creek or other changed water till well swelled out all ready to sprout. The ash requires longer soaking. Sow in moist soil in the cool of the day. A yet better way, thus avoiding the soaking process, is to spread them out thin, just before winter sets in, on a smooth and well- 
drained spot of ground, and cover with sand, decayed straw or other litter, and keep them there frozen and moist. When it is time to sow the next spring, see that the seeds are not exposed to the sun's heat. Sow them so the plants will be self-shading, and yet thin enough for vigorous growing.

\section{THE NUT SEEDS.}

The nuts of the oaks, walnuts, butternuts, chestnuts, hackberry, basswood, larch, fir, and the like-all ripening in the fall-should be gathered soon as ripe. Some may be worm-eaten; test them and other seeds in water; the sound ones sink; or, put some at random on a hot shovel; the sound ones turn over and go "tick-tack." In such ways the proportion of good and bad seeds may be ascertained. Dry as described. Mix with sand and keep in the dry cellar at about thirty degrees above zero. Plant in the late fall where you want the trees to stay. Spring planting is safe if the seeds are allowed to freeze where they will not dry up. Succor the young seedlings.

\section{PULP SEEDS.}

Use similar methods for seeds of cherries, buffalo berries, cranberries, and others of like constituency, also of pears and apples. Fall planting recommended. For fall planting, a good way is to put the seeds at the beginning of winter under inverted sods, or freeze awhile in a box of moist dirt, then remove to the cellar, being careful that they do not dry out there. In the spring expose to warm suns till they just "bopeep" from their shells; then plant, properly shading while young and tender.

\section{HARD-SHELLS.}

The heavier and larger seeds of all species of flora produce the best plants. Such seeds as the juniper, locust, white cedar, hawthorn, Kentucky Coffee Tree, etc., are difficult to sprout. They need the freezing and thawing of winter in its utmost rigor. For spring planting pour boiling water on them, and as it gradually cools, let them remain in it about an hour or more, or until some of the seeds have swelled out. These "elect" should be immediately planted in moist soil and kept moist for sprouting with certainty. Treat the still more refractory to a like dose. The red cedar seeds are harder to manage. The alkali of potash seems to be the most effectual for such.

Some seeds, the haw for instance, may be mixed with bran-mash and fed to sheep or cattle, and the droppings planted. Being softened by digestion they are thus fitted for sprouting; the same with seeds that birds swallow.

\section{SEEDS THAT DO NOT KEEP WELL.}

Seeds of the poplars, willows, elms, birches, soft maples, etc., lose their power of germination soon after ripening in the early summer, and should, therefore, be planted at once. It is unprofitable to try to raise 
cottonwoods on the prairie from the seeds. The proper place is on the sandy beach of the lake or river, where they sow themselves. The abovenamed, and all other seeds, in fact, do best on a northern or eastern slope, where the soil is moister, and the light and heat less intense.

PREPARATION OF SOIL.

Plow deep for all trees-pulverize the soil fine, as for corn. If you plant on newly broken or unsubdued soil, failure is certain on the prairie. All seeds and plants have their inalienable rights to fitted soil, light, air, water and culture.

DEPTH OF COVERING, ETC.

Covering too deep retards germination. Comparatively thin sowing gives large, healthy trees. For maximum depths, $1 \frac{1}{4}$ to $21 / 2$ inches for oaks and chestnuts; $8 / 4$ to an inch for maples, ash and box elder; 2 inches for black locust; $1 / 8$ of an inch for alder; $1 / 2$ to 1 inch for spruce, Scotch pine and larch; $8 / 4$ of an inch for Austrian pine; birch and elm as thin as possible to insure germination. Fall sowing may be covered more heavily. Have the earth cover above seed loose so that air and moisture can readily penetrate to aid in dissolving the food materials in the seed. The quicker the sprouting, the less danger to the seeds. Guard against hot air and strong light. Keep the water supply at the roots, and the degree of light and heat at the top properly balanced. Avoid too much water for the plantlets; most plants are then liable to rot.

SPRING OR FALL PLANTING.

If the ground is well supplied with moisture for the winter, it is quite safe to plant seedlings in October, such as the box elder and ash. If the fall season is dry, do not plant a tree till spring. Indeed, spring planting should be the rule.

\section{HEELING-IN.}

Trees for spring planting had better be removed from their seed-beds in the fall. They are then in their best condition, and it is wise to keep them so, and not subject the young candidates to needless wintry perils. Select a well-drained spot; dig a trench of suitable length and depth corresponding to size of your trees. Throw the dirt up like a roof. Thin out the plants side by side in the trench, their stalks lying impact on the slant. Sprinkle the dirt among the roots fine; shovel on enough for another ground-roof and another tier, and so on till all are buried. Press the earth down gently. After the ground is well frozen, cover the tips with some kind of litter. By spring the cuts and broken parts of the roots have started to heal over, and you have gained so much time. Frozen plants should be placed in a dark cellar, and the frost allowed to come out slowly.

\section{GENERAL DIRECTIONS FOR PLANTING.}

Trees one or two years old are more reliable for the field than older and larger ones, and with proper management will soon outstrip the latter in size and quality. Yuur soil must be all ready before you can unbury a 
single tree, and all your tools in proper order. Do not venture to plant while the ground is so wet as to make a mortar, or the water collects in the hole. If you do, the soil in contact with the roots tends to become hard in drying, to the great injury of the growth.

Soon as trees are taken up or received from the nursery, with a sharp knife prune off all badly bruised roots, but cut as little as possible to bring crown and root in proportion. Puddle the roots in equal parts of cow dung, clay and water. Be careful not to expose the roots of trees to the wind and sun. More failures in tree planting arise from carelessness in this particular than from any other cause. To prevent this, carry the trees to the field to be planted in bundles covered with mats; lay them down and cover the roots with wet loam, and only remove them from the bundle as they are actually required for planting. In planting, the roots should be carefully spread out and the soil worked among them. Make the roots trend downward into the damp soil. When the roots are covered, press the earth firmly about the plant with the foot. Insert the plant some deeper than it stood before being transplanted. Select, if possible, for tree planting a cloudy or a rainy day. It is better to plant after the middle of the day than before it. Protect the young plantation from cattle and other browsing animals.

PLANTING LARGER TREES.

In planting trees from three to six feet, select such as are symmetrical, free from insect pests, having broad crowns and dense foliage. It is the little fibers that sustain the life of the tree. See that there are plenty of them, compactly grown, and not impaired in bark or torn at the ends or dried up. Cover them with moist soil or moss or bags, and retain on them as much of the original soil as possible. Pruning for beauty and health should be done a year before transplanting, or may be done a year after. If you select cottonwoods, or any of the poplar family, see that they are not planted near the well or spring, for then they will surely clog them with their roots and taint the water. The method of planting, and after care, are thus summarized by Prof. B. F. Fernow, chief of the Forestry Division :

"Holes are best made before the trees are brought to the ground. They should be some deeper than the depth of the root system, but twice as large around as seems necessary, to facilitate penetration of rains and development of rootlets through the loosened soil. Place the top soil, which is better (being richer in easily assimilated plant food) to one side, the raw soil from the bottom to the other side; in filling back bring the richer soil to the bottom. If it be practicable, improve a heavy, loamy soil by adding to and mixing with it looser sandy soil, or a loose poor soil by enriching it with loam or compost. Keep all stones out of the bottom; they may be used above the roots, or better, on the surface. Providing proper drainage is the best means of improving ground for tree planting. Use no manure except as a top dressing.

"The practice of using water while planting can hardly be said to be a good one, unless the water is very carefully applied with a 'hose' after 
the soil is well flled in and packed around the fibrous roots. Water, after the transplanting (and perhaps before the last shovels of earth are filled in), especially if the soil was dry, is useful and should be applied during the hot season, choosing the late afternoon or evening for applying it. Any mulch of waste material, straw, or better, wood shavings or chips, sawdust, or even stones simply placed around the foot of the tree, is of excellent service in checking evaporation.

"To prevent the trees from being swayed by the wind, if of large size, they should be staked firmly; a loose post is worse than none. The tying should be so done as not to cut or injure the tree; a tree box insures more safety against accidents. With the development of the crown it becomes necessary to trim it, so as to carry the top above reach. Trees are not benefited by being used as hitching posts, or climbing poles, or other frolic."

\section{PLANTING ALONG RAILROAD CUTS AND HIGHWAYS.}

Nothing is more important for the traveling public than shelter belts along the deep cuts of railroads in open countries liable to snow-drifts. In such localities the trees should line both sides of the road. The soil must first be prepared as in a field. The trees-young selections from the nursery-planted and cultivated as herein directed. Put there rows of cottonwoods and willows; also, white and red cedars; white spruce and Scotch pine. Road improvement means lining them with trees.

\section{PLANTIKG ON ROCKY AND STEEP PLACES.}

Minnesota has a vast area of rocky bluffs along the rivers and lakes, many of them so barren as to be almost valueless, even for pasturage. All such should be, and can be clothed with forests. Harder places than these have thus been regenerated in the old world. It does seem that our legislature could no better serve the public welfare than to encourage their forestation by special bounties to the proprietors. If so steep they cannot be plowed, dig under the sides of the stones where the moisture generally gathers and stays, or, if this is not feasible, do as recommended by Prof. F. B. Hough, Elements of Forestry, page 57; dig "horizontal terraces or notches at convenient intervals, securing their outer edges with brush held in place with pegs. In a year or two these notches will have probably become filled up by the crumbling away of the rock above, and in the soil thus formed trees may be planted with a prospect of success." Begin with our native white and green ashes, and bur-oaks (planting the acorns) and shade the candidates with our hardiest shrubs as hereafter mentioned, not forgetting how efficient in this respect is our native prairie rose, whose tap-root will find moisture if it has to go down five or six feet to reach it.

PLANTING ON SOD LAND.

Extremely difficult to succeed with any tree planted in sod land. The binding grass even beyond the range of the roots affects them very unhealthfully. Better subdue the sods by plowing or spading. If you must venture without such preparation, then dig holes large around as a cart- 
wheel, for trees ranging from four to six feet, and at least eighteen inches deep, and fill in. Mulcil from six to eight inches deep, radiating out at least one foot beyond the circumference dug. There will be times in the dry and late summer when all the trees must have attention, the same as in the field. They begin to droop. What's the matter? Do they thirst for water? Probably. But more likely the roots are so bound, they and the leaves cannot breathe. They want air-circulation as well as water in the ground. Throw back the mulch. Stir up the soil superficially and finely; avoid harming a single root; give them enough water to drink to their fill; throw back the mulch and they revive. Just before winter sets in, water profusely to help them through the wintry drouth.

HEDGES .

As inquiry is constantly increasing as to what methods are best for raising hedges, the following from the pen of Prof. W. W. Pendergast, superintendent of public instruction, exactly answers all such letters. For a hedge, he recommends the buckthorn. His treatment of the seed can be successfully applied to the buffalo berry and other seeds for hedges:

"Soon as the frost is out of the ground in the spring to the depth of three or four inches, mix a pound of buckthorn seed with about two quarts of finely pulverized sandy soil, and having rubbed it well with the hands in a pail of water to separate the three seeds which grow in each pocket, place the mixture in a box six inches square and six inches deep, in the bottom of which several holes have been previously bored for drainage, and cover the whole with half an inch of fine soil. Sink the box in loose soil in some sunny spot, and occasionally sprinkle with soft water slightly warmed. Be careful not to water too frequently or too abundantly, as in such case the seed will rot. If the season be rainy, it will not need watering at all. The ground should be kept somewhat moist, but not wet. About the first of May begin to examine the seed to see if it has sprouted. When the little white roots begin to protrude from the seeds, make a garden bed about a rod square and sow the seeds half an inch deep, making fourteen rows, and sowing about four hundred seeds to a row. The plants should grow two years in the bed before being set in the hedge-row. Cut back to half their length and set in parallel rows one foot apart, and plant one foot apart in the row, breaking joints so that each shall be opposite the midway point between the nearest two in the other row. Prune severely for the first few years, so as to make the hedge thicken up well at the bottom. A pound of seed should make 180 rods of hedge."

SEASON FOR CUTTING WOOD.

If it be desirable to preserve the continuity and density of the plantation for future profits, and it is deemed necessary to thin out for fuel or other purposes, then cut, say when ten or twelve years old, such trees as the oaks, ashes, box elders, poplars, including cottonwoods, willows, lindens, etc., on a level with the ground, not when the sap starts, but just before it starts. Do not wound or tear off the bark. Use an adze afterwards and leave the stumps convex. Cut away such sprouts as are not 
wanted to grow. If, however, you are not in the sprouting business, but want some durable posts, railroad ties and the like, cut in the winter or dormant season, as you would mature trees for timber. Hoop-poles should never be cut when the bark will peel.

\section{INSECT DEPREDATION.}

All things have their parasites. Forest trees are no exception. Soon after the box elders and ashes, and other favorites are leafing out, millions of winged and crawling imps may be preying on their leaves, stems and roots. The writer has successfully used Paris green, thinly diluted with water and sprinkled on the plants.

But one of the most useful of the insecticides, destructive to plant parasites, is the kerosine emulsion: Dissolve one-half pound of hard soap (best whale soap) in four pints of water by boiling. When the soap is all dissolved, remove from the fire and add eight pints of kerosine, and agitate the whole briskly until a permanent mixture is obtained. This is best done by using a force pump and pumping the mixture with force back in to the vessel that contains it. The emulsion may be diluted to the desired strength and used at once, or may be used from when needed. The strength ordinarily used is prepared by diluting one part of the emulsion in ten or twelve parts of water, which makes the kerosine one-twentieth part of the whole.

\section{PROPAGATING FROM CUTTINGS.}

During wet seasons, cottonwoods, willows, poplars, etc., can be raised from their cuttings. They should be selected from well ripened and smooth-barked wood, cut with a sharp knife from eight to ten inches long, and not over half an inch in diameter. Never cut them when frozen. If cut in autumn or during warm days in winter, heel them in, or pack in damp straw or sawdust until wanted. If, just before planting, they are any way shrunk, soak them in water until plump again. A good time to cut and plant immediately is when the spring buds begin to swell. Sink into the soil the entire length on a slant, and press the earth close, especially at the base of the cutting.

SAFEST WAY.

Wm. Somerville, of the Farmers' Institute, recommends cutting notches in the bark of cottonwood, poplar or willow poles and laying them down in furrows and plowing them under. They will sprout up at the notches, and are less endangered by the dry weather. This is practical when the object is to retain the trees permanently where the poles are planted. But for healthfulness and durability, a tree from a well managed seedling is ahead of the one from a cutting, for the seedling has more tendency to tap-root itself, reaching down to the moisture and taking stronger hold. But the cottonwood's a second-class tree for the prairie at present. Col. John H. Stevens says: "It will not live in soil strongly impregnated with alkali, but when this element is eliminated by culture long enough, we shall have better luck with this trut." 


\section{PROTECTING TENDER SEEDLINGS.}

The oaks, hard maples, walnuts, basswoods, and other choice sorts need protection from hot and cold winds. Plant young box elders on both sides of the rows, and when they are strong enough to take care of themselves, remove the supports.

\section{SCREENS FOR THE TRUNKS.}

Use any white but not tarred paper. Wire-screens are a reliable safeguard against the depredation of mice and rabbits, but the most satisfactory disposal of these rascals is their extermination.

\section{HOW TO MANAGE TAP-ROOTERS.}

Spread the nuts thickly over a brick pavement or layer of broken stone; cover with rich soil and keep moist. Instead of tap-roots, the plants are compelled to send out an abundance of laterals, and such can be safely transplanted.

\section{TRANSPLANTING LARGE TREES.}

Dig circular trenches around the trees you wish to transplant, say three or more feet from the trunks, and, when the ground is solidly frozen, draw them down with the team, thus retaining the roots imbedded in the dirt. Haul to the lawn, and plant in the great holes dug the fall before, staying the trees with long timbers, or better with wires:- This feat being performed in the winter when the sap is stagnant, the roots are protected from damage, and in the spring when the old elms wake up, they will hardly notice the change, except from the new associations they have formed.

\section{CULTIVATION.}

It will not harm the young seedlings in the least, but help them greatly, when the weeds peep up, and before the leaves have unfolded, if you drag the harrow over. This saves a great amount of time and labor. Soon after this process, the soil must be stirred by the cultivator frequently and more and more shallow as the season wanes. By the middle of July hold up. The cells of the plants have then about reached their full development. They must now have time to ripen for the winter's ordeal. 'If you cultivate later you dangerously prolong the ripening process, thus quickening the circulation and weakening the plants. Let the weeds then grow; they are a splendid protection, trapping, too, the snowy mantles. Living, healthy plants next spring-success !

\section{HOW TO MANAGE OUIR DRY SOILS.}

As to soil, there is no country on the continent better adapted to successful tree culture and all sorts of plant culture, than the prairie. The soil possesses the necessary ingredients. It is dark colored, and, therefore, heat-drawing from the sun. It generally has under the surface soil a clay sub-soil that holds the subterranean water from running away. It exists in sufficient quantity in depth for all our purposes. 


\section{THE DRAW-BACK.}

A lack of water is the great draw-back with us. We have not enough rainfall to supply our full needs. We are therefore driven to the necessity of economizing what moisture we have with the most vigorous energy. Plowing up the soil breaks its sodded crust, allowing water to filtrate downward to the clay beds and chambers, held there in reserve for use. What a beneficent provision this in the divine economy of nature!

\section{OUI PRIVILEGED DUTY.}

Rains are fortuitous; we are not yet able to control them. To depend exclusively upon their descent makes our agriculture as uncertain as the winds that so mercilessly beat upon our crops. The business in hand is to economize what we have, to control the water content of the soil. Generally in the spring the soil is well saturated with moisturo.

\section{SOIL-TAPPING.}

Spring plowing taps the soil, verily bleeds it to a dry death. Fall plowing is not attended with much evaporation. The winter snows and winds pack it down to the right condition for plant growth. It must be kept thus packed through the entire growing season. If we keep gouging into it with the shovels of the cultivator, we not only neutralize largely the capillary action, but we open innumerable and dangerous ducts into it, producing rapid evaporation, and soon all our water reserve is lost and our plants die. The trouble is, we stab the sub-soil; we cultivate where the teeth of the cultivator have no business to be. The essential work to do is to expose the least possible amount of soil to the action of the sun and winds.

\section{SOIL-AERATION.}

But the soil must be stirred just enough to break up the surface crust, formed by deposit of saline particles brought up by capillary action and virtually baked in the heat-ovens of the sun. The thing to do is simply to harrow up this crust and transform it into a fine "dust blanket," flexible enough to let in the air close enough to husband the moisture just under it. An intelligent prairie farmer sensibly says in the Annual of Farmers' Institute, vol. 5, page 96 :

"It is essential that the air be admitted within the soil to bring with its coming, oxygen and nitrogen, and take in its going the carbon dioxide liberated in the soil. This coming and going of the air in the soil may be called soil-breathing. The germinating seeds, growing roots and germs of ferment, germs of nitric acid and free nitrogen fixing germs, all breathe the air, all are essential to soil fertility, and to exclude air would surely cause a poverty of crops."

It is plain, then, that cultivation must be thin and frequent during the dry season of plant growing.

\section{THE EVERGREENS.}

Among the evergreens suited for our climate are our native white spruce, red and white cedar, white and red pine, Norway spruce, bull pine. Those 
from the wild forest are not as well rooted nor so hardy as from the nursery; but with care in plucking up, packing and planting, never exposing the roots to the sun, they can be made to live and do well. Best evergreens have been transplanted two or three times. The smaller sizes, from three to four years old, are the more reliable. They should be planted on the lawn, here and there one and sometimes in groups, and around the stock yard, the barn and other out-buildings, hiding deformities. There is no better wind-break for the orchard or garden than evergreens.

\section{PLANTING EVERGREENS.}

Keep the roots moist; never expose them a moment to the sun or wind. Drying coagulates the juices and stops the circulation. "For better protection," says the Jewell Nursery Company, "mud the roots and put in the ground before it dries on. Such treatment is better than pouring water into the hole." Don't put in the tree as you would a post. Make the hole large and deep and fill in the best loose soil. Spread the roots out natural. Do it quickly. Put the plant down an inch, at least, deeper than it grew in the nursery. Sprinkle the dirt in fine; press it around the roots close; shovel in and press down, and so on till the precious thing is so well planted you cannot pull it up. Leave a film of unpressed dirt on the surface; have the ground dip toward the tree to catch the rain. Mulch on the surface and out over and beyond where the roots are.

\section{KILLED BY WATERING.}

Trees do not live on water alone, but mainly on the nutrition of the soil, the water assisting in the process of preparing the food they need by contributing its share of the oxygen. Too much water gormandizes, neutralizes the chemical action, or vegetable digestion, so to speak. Very often cold water, direct from the well, is sprinkled on the plants, which tends to chill them to death, and these little dribblets seldom reaching the roots, form a hard crust on the surface soil, excluding air circulation, and, of course, the plants die. Mulching well economizes the ground moisture and assists in developing ammonial properties, so essential to plant life. My idea is, that when all the ground is "dry as chips," best to water among the roots with sunned water, and "let them alone."

\section{RAISING EVERGREENS FROM SEEDS.}

Procure the northern grown. The one year old are surest to sprout. They are found at the base of the scaly shells to the cones in which they develop. Sometimes they drop out before the cones fall from the parent tree. Then again they may remain in their cozy homes long after the cones have fallen. Even as late as June, the seed in this condition can be found. For surer harvest better gather the cones just before the seeds are ripe, say from the last of October till the middle of November, and gradually dry them. Generally the shells will open by this process. When they seem to be refractory, subject them to artificial heat, and the seeds are sure to fall out. Keep in a cool, dry place, excluding the light, and plant in the spring in moist soil. 
As a rule, it does not pay to raise evergreens from the seed; but there is a pleasure in success and profit with the pleasure. Almost any kind of mould will do, but sand-leaf mould is preferable. Locate the bed where mice and squirrels are not masters of the situation. Sow broadcast; sift the covering on about an inch deep for the larger scrt, such as the pines and Norway spruce. Raise up side frame about six feet for air circulation. Have portable latticed covers to shade or remove, as needed. Can be made of lath or brush. Protect against bright suns both summer and winter. Remove the shades after ordinary rains, and put back when the bed is well dried off. A like treatment is necessary for evergreens transplanted from the forest. In warm and moist weather the seedlings are apt to dampen, a peril that can generally be prevented by covering the bed with a coating of sand.

THINNING THE FOREST.

Trees will thin themselves in due time. But, understanding nature's laws, we can apply them, if wise enough, as aids, and sooner accomplish the ends sought. With scarcely an exception, the owners of our native woodlands cut and slash indiscriminately, without a thought as to effects. In cutting trees for fuel or lumber, the reckless rule is, cut so as to get the most immediate profit. Even if fires do not follow the ax, the wide gaps made, open the way for the sudden ingress of scorching suns and sweeping winds, drying up and tearing to pieces the remnant. That forest is the same as ruined. Sad to relate, such is the common condition of the old woods of Minnesota. Trees growing compactly side by side are comparatively tender, unfitted for sudden exposure that breaks the balance of mutual support. If the object be to preserve a forest, and yet draw from it supply for home or market, do not cut out over a quarter, or at most, a third of the trees the first year; and this thinning must be judicious, cutting here and there a tree, always with a view to improvement. Then wait two or three years before thinning much more. The idea is to give more room for root-taking and limb-branching, maintaining the continuity of the forest arch or roof, the trees standing up symmetrically to grand heights and dense foliage.

\section{ART OF PRUNING.}

Avoid everything set or stiffly artificial. Trees should be pruned to healthy conditions, and beauty of form will naturally ensue. Ignorant pruning is one of the unpardonable foes to a tree. Very frequently-indeed the rule of thoughtless intermeddlers with nature's beautiful art of self-preservation-the branches are sawed off an inch or more from the tree-trunk. It is impossible for nature to heal such wounds. Always prune close to the bark. The roots of a tree are proportioned to the branches. If then you saw off large live branches which nature cannot heal over, the roots at once begin to die, and the rotting roots convey rottenness to the trunk. The bungling pruner virtually stabs the tree to the heart, for the stumps he leaves on soon rot, and convey the rotting tendency downward as the rotting roots do upward. A severely pruned, or a 
badly pruned tree soon becomes hollow, and seldom-lasts many years. Prune when the trees are young and "be harmless as a dove."

SEASON FOR PRUNING.

All our foresters and horticulturists agree with J. S. Harris, that from June 25 th to July 10 th, is emphatically the season for summer pruning fruit and ornamental trees. The secret of good pruning is : Never permit a useless limb to grow. The main part of the work consists in rubbing off the sprouts that will make superfluous branches, and pinching in such as are making excessive growth in the wrong direction, and will tend to throw the tree out of symmetry. If necessary, branches less than a half inch in diameter may be removed and the healing process will begin at orce, but care must be taken not to remove too much foliage at one time, for it will injure the vitality of the tree.

\section{TREES GNAWED BY HORSES.}

"The gnawing of the bark by horses," says Thomas Meehan, "shortens a tree's life considerably. If the bark is removed half around the tree, only one-half the necessary amount of moisture and food that the tree requires can be drawn. In a very dry time such trees suffer seriously, and either die at once or dwindle gradually away."

\section{TREATMENT OF TREE WOUNDS.}

Discreet surgery is as necessary for our trees as for our teeth. Prof. C. A. Sargent, of the Bussey. Institution, translatiug from the French, gives us practical hints. Cut away cleanly all loosened or injured bark., Cut smooth a regular outline, especially on the lower side. Leave no dead pieces for insects to hide under. Then apply a coating of coal-tar.

\section{CAVITIES IN THE TRUNK.}

Cut the edges of the cavity smooth and even; remove all decomposed matter; apply the coal tar to the surface of the cavity; plug the mouth with a piece of well-seasoned oak, securely driven in; smooth down the end of the plug; cover the whole with coal-tar, and nail on a piece of zinc or other metal, in such a way the growth of the new wood will in time completely cover it. "Coal-tar has remarkable preservative properties, and may be used with equal advantage on living and dead wood. A single application, without penetrating deeper than ordinary paint, forms an impervious coating to the wood cells, which would, without such covering, under external influences, soon become channels of decay. This simple application then produces a sort of instantaneous cauterization, and preserves from decay wounds caused either in pruning or by accident. The odor of coaltar drives away insects, or prevents them, by complete adherence to the wood from injuring it."

\section{COPYING NATURE'S METHOD.}

Experiments have been tried and with considerable success to raise forest trees by sowing broadcast the seeds of the box elder, ash, oak, birch, 
sugar maple, hackberry, etc., as is done in some parts of Europe where conditions warrant. This method has promise where the soil is moist. The crop the year of the seeding must be a clean one, say of corn or potatoes, and all the weeds and grass absolutely subdued. The plowing must be deep; well to use a sub-soil plow, and harrow the land till as mellow as an ash heap. Then mix the seeds together promiscuously, sow broadcast, putting on a liberal quantity, and harrow them in. Next spring they will come up thick, but will thin themselves out on the principle of the "fittest." The growth will be comparatively slow, but healthful if the weeds are hoed down during the growing season. In due time you will have one of the best and most beautiful forests on the open prairie. This is the cheapest way by far. Try it.

\section{GRAFTING-HOW TO DO IT.}

Grafting to improve the stock of trees is of late commanding the special attention of the friends of forestry. The following rules are applicable to fruit, as well as timber trees:

"The kind of grafting most likely to be practiced on the farm is that known as cleft-grafting. The process is a simple one. Saw off the limb to be grafted where it is an inch or less in diameter; trim the edges of the 'stub,' smooth and split it with a large knife or a cleaver made for the purpose. The cleft should not be more than four inches deep at the most. A wedge is now inserted in the centre of the cleft and a cion is set on each side of the cleft. The cions are made of twigs of last year's growth. They should be cut before the trees show any signs of starting in the spring. When the cion is prepared ready for setting, it should contain about three buds. The lower end is cut wedge-shaped by slicing off each side of the cion. On one side of this wedge-shaped portion, midway between its top and bottom, should be left one of the buds. When the cion is set, this bud will be deep down in the side of the cleft in the stub, and will be covered with wax; but, being nearer the source of nourishment, it will be most apt of any buds to grow, and it will readily push through the wax. The cion is set into the cleft by exercising great care that the inner surface of the bark on the cion exactly matches with the inner bark on the stub. A line between the bark and wood may be observed. This line on the cion, in other words, should match the.line on the stub. Wax the whole over carefully and thoroughly. Do not leave any crack exposed. Grafting wax is made as follows: Melt together resin, beeswax and tallow in equal parts and spread on cotton cloth. Tear into strips and wrap around graft." 


\title{
ENTOMOLOGIC.
}

\section{BARK INSECTS.}

\author{
By Prof. Otto Lugger, State Entonologist.
}

It has taken a long time before the American nation has realized that it is not only very important to protect such trees as arestill found in our more or less ruined forests, but that it is also equally necessary to plant trees to re-forest the more denuded portions of our country. The most strongly expressed objection to engage in planting and fostering forests has been a question of dollars and cents. It was and is claimed, and not without reason, that it requires too many years to grow trees of a sufficient large size to be converted into lumber, and that the duration of a human life was not long enough to enable those planting forest trees to harvest the crop or to realize on the investment. Such has been the opinion of the generations before us, and as they simply cut down trees but did not plant any, or take the proper care of those planted by nature, they left the present generation no inheritance. In fact, the last generations have done what we are doing now: living simply for the present, not caring for the future. Our case is like that of King Louis XV., who said: "Aprés moi le déluge," after me the deluge. But this period in a spendthrift's life has to come to an end, and whether we like it or not, this generation has to make good what former ones have neglected, or have blindly destroyed. But this is not the space to discuss this matter; it has been discussed again and again in these pages. "To grow a forest, it is simply necessary to plant a large number of trees in a more or less regular manner;" this seems to be the idea most persons have of producing a forest. But this is by no means the correct one. It is not only necessary to plant trees, but it is equally important to protect them against their numerous foes, both animal and vegetable, and also to take proper care of the trees that already form forests. Of course, it is not even possible to mention the names of the mammals, birds, insects and other animals that are more or less intimately connected with a forest, both as friends and as enemies. But among the most important enemies of our trees, we have a large number of insects that belong to the order of beetles, and which are usually called bark-beetles. This name does not, however, indicate that they simply live in the bark of trees, or that other insects may not occur there. A glance at the illustration will give a good idea of the insects and their work, sufficiently, at least, to make it unnecessary to give a long, technical description of them. 
Bark-beetles are entirely dependent upon vegetable food, and spend almost the whole period of their existence inside a plant. The only time that they are found outside of their home lasts but a few hours, and these moments they utilize for their love affairs, and to select a home for their offspring. With few exceptions, all bark-beetles occur in the wood of trees and shrubs, and but a very few species are found in parts of smaller
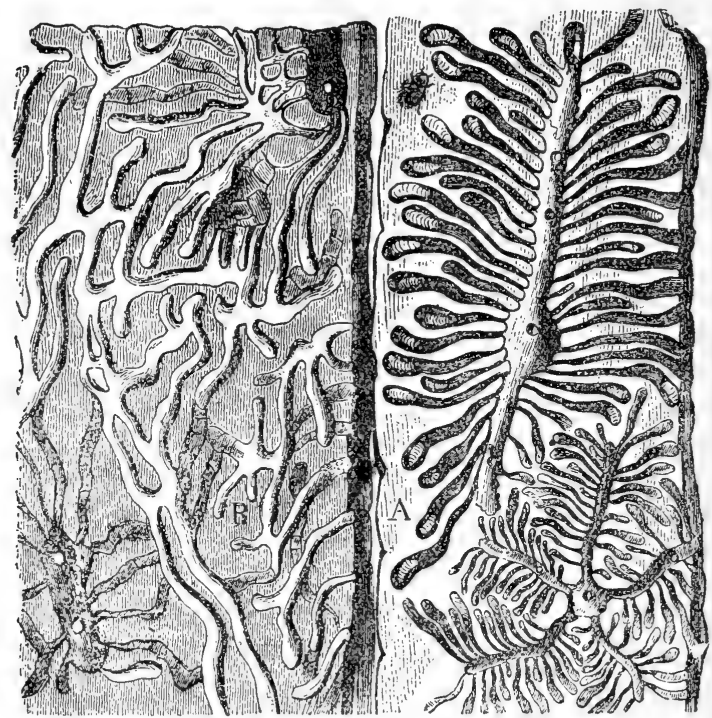

Work of different kinds of Bark-beeties. In the figure at the right are seen the primary and secondary tunnels, with the larvæ in them.

plants. None of them eat leaves and flowers. Most bark-beetles hibernate in their perfect stage in the galleries made when larvæ, and a few in the pupal stage. Early in spring, or as soon as it is fairly warm, these beetles awake from their torpid condition, and leaving the tree soon afterwards, swarm outside their old home. As we have a large number of species of these destructive insects, there is naturally a considerable difference in the time of their swarming. Their flight is heavy and not very rapid. During this time they have to search for proper places upon suitable trees in which to deposit their eggs, which takes place soon after copulation. The female beetle gnaws a hole in to the chosen tree; after reaching a certain depth, it usually turns at a right angle, and continuing makes a straight 
burrow. As this burrow or tunnel becomes longer, eggs are deposited in it at more or less regular intervals, though in some cases all are deposited in one or more little heaps. The larvæ or worms hatching from these eggs gnaw a burrow away from the one made by their mother, and thus frequently form a very regular system of tunnels, as may be seen in the illustration. Each species has its own method of work, so that an expert can readily judge from a tunnel the species that made it. These larval tunnels become larger and larger with the growing larvæ until the full-grown larvæ cease their labors at the end of the tunnels. They now change to pupæ, and later to beetles, which, after hardening their outer skins, reach the light by a straight burrow leading to the surface of the trunk.

We have a large number of species of bark-beetles which vary considerably in the method of leaving the burrow in which they grew, in the method of swarming, in the manner they search for new homes for their offspring, in the formation of the new tunnel, in the way they deposit eggs, in the time required to grow, in the number of annual generations, and in many other ways not necessary to mention here. Some species of bark-beetles find their food only in the bark, others between the bark and the wood, and still others in the solid wood itself. Of course, this difference causes differences in other habits, but chiefly in the arrangements of the holes through which they reach the surface. As no barkbeetle will fiy during a cold and rainy day, nor in cloudy weather, but only during the time that the sun shines brightly, the irregularity of their appearance outside the tree is readily accounted for. In selecting the proper tree for the reception of its eggs, the female beetle is very careful. Each species will investigate with great care a tree before it is selected. Beetles that breed in pine trees will not fly to oaks, and such as live in maple will not settle upon linden. Some will select the roots, others the trunk, and still others only the branches or smaller twigs. This constancy in selecting the exact kind of tree and exact spot upon it is explained by the difference in the jaws and other organs of the insects, which would make it very difficult to gnaw or burrow in other trees. But they select with such great care, not only the kind of trees, but also their conditions. Trees that are dead are never selected, as they would not be able to furnish the required fluid food. Perfectly healthy trees are also discarded, because the larvæ would be drowned by too much sap. Such species of bark-beetles as are hairy, can live in trees like pines, notwithstanding their sticky sap, which would smother beetles with a smooth skin. Trees that are injured by heavy winds, by careless felling of neighboring trees, by the scorching of fire, or have become diseased by other accidents form the best homes for bark-beetles and are the ones that are always selected. If, however, such diseased or injured trees should not be found, healthy trees have to be utilized by these insects.

Bark-beetles are strongly influenced by climatic conditions, by cold, rain, or absence of sunshine. To escape such unfavorable conditions the beetles make as soon as possible a burrow in the chosen tree, so that they have a retreat in bad weather. In these retreats they can also escape their numerous enemies among birds and carnivorous insects. In trees with a 
rough bark the cracks are selected and thence the beetle enters the bark. To make a hole large and deep enough to hide, the beetle requires from two to three hours. All such holes are perfectly round, and their different sizes indicate the sizes of the beetles that made them.

Species that live in solid wood lead a life different from that of those living in the bark. In the former case the mother makes all ramifications of a burrow, and then deposits many eggs together. In this case the larvæ eat nothing but the sap that enters their tunnels. In the latter case the larvæ themselves have to make the secondary burrows, each living singly in one. Of course, the primary tunnel is made by the mother. Dead trees can not furnish food for either of these larvæ, as they are without fluid sap. If a tree should become too dry before the larvæ mature all have to perish for lack of food; if it should simply become very dry the length of the larval existence will be greatly lengthened so as to give them time to find all the food required to reach their full size.

Most species of bark-beetles require about eight weeks to undergo all their transformations from the egg to the adult insect, and consequently a number of generations can be produced in a single year under favorable conditions. It is of great practical importance to know the number of generations, and the exact time in which the beetles swarm, since upon this knowledge must rest the methods to combat them successfully. This important knowledge is still lacking in the great majority of cases, and before it is acquired all proposed remedies will be more or less unsuccessful. Bad weather, rain and snow, except during the time of swarming, have but little influence upon these noxious beetles, as they are so well hidden and protected inside their solid home in a tree throughout almost their entire period of existence. This explains why insects of this kind can exist in such large numbers as far north as trees grow, and in the mountains almost to the snow line.

No other family of beetles is so destructive to trees as the one composed of bark-beetles, and consequently they are feared whenever forests are taken care of or where new ones are planted.

As far as remedies are concerned, only a few practical ones can be mentioned. Since "an ounce of prevention is better than a pound of cure," we have to remove all wood from the forests that has been cut a short time before the swarming period of such beetles. This is very important. A second remedy, and one that has to be carried out at the same time as the first one, is to prepare some trees as traps for the insects flying about to deposit their eggs. This will prevent them from depositing their eggs upon more valuable trees. Removal of freshly cut trees from the forests without preparing traps is worse than useless, as it is rather an invitation for the insects to increase upon good timber trees. Since we know that barkbeetles prefer recently injured trees, we have to prepare a number of such trees as traps. In the bark of such trap-trees the majority of the flying females will deposit their eggs. By removing the bark of such trap-trees after five or six wetḱs, and by burning the bark, an immense number of the immature bark-beetles will be destroyed. By preparing a number of 
such traps at intervals of a few weeks, and by burning their bark, we can greatly lessen the danger. With care, bark-beetles can be kept in check.

\section{OTHER INJURIOUS INSECTS.}

Their name is "legion" and their depredations beyond control. Beetles, moths, caterpillars, vegetable lice, don't they multiply? Wilson, the ornithologist, pertinently asks: "Would it be believed that an insect no larger than a grain of rice, should silently and in one season destroy some two thousand acres of pine trees, many of them from two to three feet in diameter and a hundred and fifty feet high?"

Fight them we must. How? With poisons; and thereby we endanger the existence of our

FRIENDLY INSECTS.

The wild honey bees that store their food in the hollows of the old trees are the fertilizers of the forest flowers. By their instrumentality the forest is perpetuated and improved. How do men reward them for this providential beneficence? In the dead of the winter they rob them of all their honey and kill them. The wood-wasps are also pollen carriers. As they store no honey to rob, men send shot through their nests or burn them up. The demons of ignorance and rapacity are at work by ax and fire and bee-killing, and the forest recedes and rots and dies. But for the friendly insects we would have precious few trees or crops of any kind.

\section{OUR INSECTIVOROUS BIRDS.}

Frank H. Palmer, in "Agriculture of Massachusetts," aptly says: "If left to herself, nature establishes a wholesome equilibrium between the feathered and insect tribes. She produces no more insects than can be kept in check by the birds. But man, by his artificial habits, disturbs the proper balance between these tribes. By cutting down the woods, by disturbing the quiet of the forest by the sharp report of the gun, he destroys or drives away the birds, and thereby stimulates the production of insects, which become almost the greatest pests of the agricultural interests of the country. Nature has given to birds an appetite and an instinct which teaches them exactly when and how to go to work to capture and destroy insects and their eggs; and if the number of eggs produced by insects is wonderful, so the number destroyed by a single bird is marvelous. Bradley says that a pair of sparrows will destroy 3,300 caterpillars in a single week." Another reliable ornithologist states that two old birds with five young will destroy in a single day's feeding 700 insects. If two birds can do so much work for us, think of the vast multitude of birds in the fields, as yet 
escaped the hunter's onslaught upon them, and we can get an approximate estimate of their helpfulness in protecting our forests and agricultural interests.

Ants do a great deal of mischief sometimes. A brood of partridges will eat up a whole hill of them in a day, but the hunter does not hesitate to shoot the last partridge even when rearing her young.

\section{FOREST ZOOLOGY.}

\section{OUR GAME ANIMALS.}

Except where the law defines when men may or may not trap and kill them, no provision has been made by the state to protect, much less propagate, our valuable game animals, such as the moose, the deer, the otter, the beaver, the bear, the fox; and such prohibition is generally a nullity when the hunters get into the woods. They pay no regard whatever to the preservation of any such animal. They like to kill the wolf because there is a bounty on it. They are more likely to let the lynx live, though he is said to kill more young deer than the wolf. Like the angler and the axman, they take the last of the best, caring nothing for the needs of the future.

Our moose, once quite common, are nearly extinct. The law now forbids shooting them at all, but this makes no difference with the hunter when he gets a chance to shoot one. Our deer are lessening. The slaughter of them is by the wholesale. A few years ago the beaver and otter were numerous; now and then a solitary one is found, and that is trapped. The bear is meeting the same fate, and so the fox and the mink. In a slight degree our laws do check the spoiliation, but in the main they are inoperative. Our game animals-they are going with our native woods. What an utter absurdity to pass laws regulating the shooting, and yet do nothing to save the forests in whose fastnesses they seek a refuge and find a home!

\section{MARSH HAWK, Circus Hudsonius.}

This hawk, common in our woods and prairies, lives on crickets, lizards, frogs, snakes, small wild birds, and domestic chickens when the shepherd dog is not around; but does not kill a tenth part as many of the latter as the skunk, that is pursued with less onslaught. Mice and gophers constitute a major part of the hawk's food. Valuable as its service is, most everybody tries to exterminate this "warrior of the skies." 
Dr. A. R. Fisher, of the Division of Ornithology and Mammalogy, Washington, D. C., says: "Although this hawk occasionally carries off poultry and game birds, its economic value as a destroyer of mammal pests is so great, that its slight irregularities should be pardoned. *** The marsh hawk is unquestionably one of the nost beneficial as it is one of our most abundant hawks, and its presence and increase should be encouraged in every way possible, not only by protecting it by law, but by disseminating a knowledge of the benefits it confers. It is probably the most active and determined foe of meadow mice and ground squirrels, destroying greater numbers of these pests than any other species, and this fact alone should entitle it to protection, even if it destroyed no other injurious animals." Report of Secretary of Agriculture, 1889, p. 3r2.

\section{COMMON SCREECH OWL, Megas copsasid.}

This wood-haunting ow] is no better appreciated than the hawk. It does sometimes knab a partridge, a prairie chicken or a warbler, but its favorite dish is mice and gophers; and at night it is on the hunt for these rodents in the forest brush, in the orchard and field, around the barn and corn-crib. This and the Burrowing Owl also relish grasshoppers, crickets, beetles, etc. Dr. Samuel Aughey says: "It is largely an insect-eating bird." A great mouser is the owl, and sensible farmers let them stay during severe winters in their barns, thus protecting their grains. Let the wise old owl, then, be "fruitful, multiply and replenish the earth."

\section{GAME BIRDS.}

Among our most valuable game birds of the forest and water-dotted meadows, are the ducks and wild geese. The partridges, prairie chickens, plovers, grouse and quails should also be included in the list. The meadows of the wild woods are their hatching grounds. Fast as these dry up under deforestation, they retreat. Preserve the woods and they will propagate to bless us by devouring insect pests and supplying our tables. "As long as there are no retreats or building-places where the feathered friends of ours can rear their offsprings, we need not look for their aid in fighting our insect enemies."

\section{AN UNPARDONABLE FASBION.}

Not less than 5,000,000 birds are annually murdered to adorn the hats of women and young misses! They wear them even to church and listen to that gospel which teaches that "Not a sparrow shall fall to the ground without your Father's notice."

\section{BIRDS PLANTING FORESTS.}

The benefactions of our birds are by no means circumscribed to protection of our crops by their devouring preying insects nor to the food they supply us with. In his "Origin of Species," Charles Darwin shows how certain birds annually cross the Atlantic, bearing forest and other seeds adhering to their claws and beaks, depositing them on the islands and continents, some of which will spring up and live. It is not too much credit to say 
the birds and squirrels have planted the forests of the world, and by right they are theirs to live in. With a view to save them for food, no doubt, like the dog that buries his bone of meat, crows have been known to dig holes in the ground with their beaks and there deposit acorns which sprout and grow into great oaks. No birds, perhaps, have done more to carry seeds from one part of the world to another, taking root where they can, than the wild geese, which are fast learning to leave us for other regions to escape from utter extinction.

\section{INSTRUCT THE BOYS AND GIRLS.}

Considering the inestimable value of the mammals and birds herein mentioned, also of other insectivorous birds, such as the wood-pecker, the robin, the thrush, the wren, the swallow, the meadow-lark, the rose-breasted grosbeak and yellow-billed cuckoo (scarce in our state), that feed upon caterpillars and potato bugs; considering, too, the value of our fishes, whose best qualities always obtain in our cool woodland waters, it does seem that, aside from more efficient laws, our educational curriculum should include forestry and forest zoology, applicable to all our graded schools. As we love our country and aspire to make it better for our living in it, the very best we can do is to so instruct the boys and girls that they will devoutly care for and perpetuate the natural bounties we all inherit.

\section{ECONOMIC.}

\section{WILD CONDITIONS.}

In its wild state the prairie cannot reforest itself. Long before the white man came, the nomadic Indians scourged it with fires for centuries; buffaloes and grasshoppers devoured every sprouting tree; and ever after this desolation it has been beaten and "ovened" by dry winds, forestalling the needed precipitation. Hence our hard struggle to make a beginning of reforestation. After several years of soil culture, we are safe to venture with pioneer trees. In one sense "the forest creates its owh favorable conditions of growth." But we must first comply with the conditions of starting the forest. Scattered trees cannot stand the strain. "It is the effective shading of the ground that the changed conditions under the forest cover will be brought about; it is by masses of trees that the sun's power is broken, and it is by large areas distributed over the vast expanses that ultimately the force of the winds will be broken." 
COLD AND SOUR LANDS.

"Allow no stagnant miasma holes," says Col. John H. Stevens, "nor useless eyesores to destroy the symmetry. of your lovely farms." Considerate attention to adaptation of soil to tree and tree to soil is just as essential in the art of forestry as on any other special line of agriculture. Suppose a farmer has a slough of cold and sour soil and wishes to cover it with trees-the very best use-what should he plant in it? He should plant none until he has eliminated the cold and sour conditions by plowing, pulverizing and crop-raising, until the alkaline salts are dissolved and thus prepared for tree appropriation. Then he may be able to raise there almost any species of indigenous trees.

THE DESERT PATCH.

Suppose he has a high and dry, gravelly or sandy. patch, what can he do with it to best advantage? He has never raised anything on it, and despairs of trees, for he may not have succeeded on good soil-not knowing how, or if knowing, not having done his duty. He is no farmer who lets his soil be master. Work it up, as with the slough, and sow on it, in the late fall, about two bushels of ash seeds per acre, and harrow them thoroughly, and thinly cover the entire area with straw, manure or other litter. Next spring they will sprout up. Then keep out weeds and fire and let them struggle on. They will soon begin to replenish the soil by carpeting it with decaying leaves that hold the moisture and feed the trees. Within a decade you can safely introduce soft maples, box elders, elms and other trees, for you and nature in harmony have made a soil to grow them in.

\section{CRANBERRY AGRICULTURE.}

The wild swamps among the woodlands-what has nature put there? Scrawny black spruces, clumps of tamarac here and there on iittle raised islands, pitcher plants, blueberries, mosses innumerable. The peety stuff underneath is water-soaked. It were unjust to nature's economy to call such lands unprofitable as they are. They are her reservoirs, held there under the moss and vine covering, keeping up the water-flow to the lakes and rivers. But it is improvident to let them remain in their wild condition when land is so much in demand. They should be drained, and the drainage controlled, so that the outflow shall not run to waste, but be husbanded in the great lake centers and canals ere long to be dug for irrigation. This done and surface soil prepared, no farming and no other business could be so lucrative as to devote these swamps to cranberry agriculture.

Thus it is that our sloughs, our desert patches, our swamps and bogs, our oak-openings, our burnt districts, our stony ranges, our bluffy slopes, van, by proper management, be covered with trees and used for wild fruit raising of some sort.

\section{NATURAL FORESTRY INSUFFICIENT.}

When we undertake retrenchment along this line, why not do it business like? Nature takes no cognizance of the wants of our industries. Natural 
selection of flora is what will survive in the struggle for existence, irrespective of value to us. Practically not over twenty-five per cent of all the forest trees indigenous to the state should be specially encouraged for tree culture. The "fittest" means the most needful and profitable. Growing the "good, bad and indifferent" is far from wise economy. "In the forests of the future," says Adolph Lue, secretary of the Ohio Forest Bureau, "no tree of an inferior or no commercial value, unless it is used as 'nurse trees,' should be or will be tolerated."

\section{INDIGENOUS VS. FOREIGN TREES.}

There is a sickly mania prevailing in our towns for the introduction of foreign trees not adaptable to our climate, when some of our native trees, perfectly acclimated and equally if not mor beautiful, are scarcely noticed. The state has especially provided at our Experiment Station for tests as to fitness of foreign vegetations, and it would be a saving of expense and a surety of greater success in the tests, if people would give heed to what is recommended at heaciquarters. Before looking abroad for the rare and novel, common sense suggests that we first develop our own forest resources and plant and save what is reliable and useful and beautiful. All things considered for an evergreen, what from Europe or anywhere else in the world can excel our native white pine, or any of our substantial oaks and lindens or ashes? We have growing wild innumerable quantities of flowers and shrubs, which, if culled out and cultivated in our home arboretums, would emparadise our state. Why not seek and cherish the things of value in all our woods and shady nooks and pay as yet less attention to the foreign, which may fail us?

PARKS FOR ALL THE PEOPLE.

Much attention is paid to parks for our cities, and most of our villages follow suit. Nothing contributes more to the health and contentment of the masses than these rural retreats. But why limit park improvement and its educative influences to the populous centers? The monotony of country life that tends to drive the young folks into the surfeiting cities can be largely neutralized by legislative encouragement to the development of public parks in the country places. One of the very best ways to enrich the state is to transform the waste lands in every county and township into free forests for the people's rest and recreation, serving also as public wind-breaks and water reservoirs.

A few years ago congress set aside a limited tract of wild land at and around Itaska Lake for a state park. This has nothing to do with the proposed forest reserve, and is based on an entirely different plan. Its area ought to be enlarged the better to subserve the object sought. Itaska Park deserves special care and public favor. It is all important to rescue the pines there from being stolen, and all that picturesque region from fires, thus conserving our streams and lakes at the headlands of the Mississippi. 


\section{RECKLESS WASTES.}

Take the country over, it is safe to say that ten per cent of our soil runs off into the streams and rivers, utterly lost to us. We are thus losing the best part of our farms. Silly men, what have we been doing to impoverish our lands and pockets? Why, we have planted to the water's edge; plowed the slopes and inclined plains, without making any provision whatever to prevent waste of 'soil, till, in some places, it becomes sterile as that of Sahara. Not infrequently we have thus bared it to the under-stratum of gravel and clay. Heavy showers and hot suns have hardened what is left, preventing the water from soaking down for subterranean drainage, and away goes the soil and debris down the slope, reducing the value of the farm, piling it into the rivers, making harbor improvements more expensive; and then men wonder why they have poor crops.

\section{NEXT THE FLOOD.}

Small causes combined produce great results. "The numerous tiny rills and runs, scarcely noticed by the farmer, center their quota in the river, multiplying at every advance, and then the flood, carrying off our soil, drowning cities and villages, destroying immeasurable property and many lives." People look on dazed and call it "the anger of God;" and it is His anger in the sense of reaping what we have sown-the penalty of . neglect and misuse. Only a forest economically managed can prevent these wastes and ruins. "The forest cover with its interposing foliage and undergrowth, its protecting floor of fallen leaves and twigs, its intricate root system and its fallen trunks and branches, first retard the rain on its way to the ground, thus breaking its force, and then retard the surface drainage and prevent the rush of water which takes place over naked soil."

\section{FOREST FIRES.}

Travel on what line we may, we are confronted with burnt districts. All along for miles upon miles it is one continuous blackness of despair. The tamaracks in the swamps are swept down as by a cyclone. Here and there stands a dead pine amid the dread solitude. Among the black stumps some forlorn poplars are trying to get a foothold--a sad retrogression of our timber lands. Farther back from the railroad here and there are clumps of living trees, but without exception in every place where the pines have been recently cut and huge piles of refuse left, the ruinous effects of fire are seen in all their terrors. In other localities, where limbs and leaves have accumulated for years, the fires have also swept and killed all the young growth, and more or less injured the large trees. See how their angry tongues have lapped to death the yellow and white birches, even eating far down into their roots! These and valuable pines and oaks are a prey for worms.

Millions of dollars worth of property, consisting of timber, camps, implements and hay-stacks are destroyed every year. Remote homes are burned up, and sometimes whole villages, and hundreds of lives lost, and yet absolutely nothing is done to avert such calamities. Lumbermen 
and resident settlers say, "It does not pay to try to suppress the firescourge." Were the fire uncontrollable, like a cyclone, there might be some sense in refusing to meddle with it.

Most of the forest fires are the result of sheer carelessness. Campers do not vigilantly guard against the escape of the cooking flames; poachers let them run; men throw burning cigar-stubs into the dry tinder, and in an instant the woods are on fire; men set fire to their "felled piece," or a dry grass meadow, that their stock may feed on the subsequent green herbage, and away the angry fiend leaps and rushes, till millions of property values are ruined in an hour; sparks from the railroad engine ignite the combustible stuff along the thoroughfare, and the engineer drives on ahead and lets the ruin go on. As if it would not pay to do something by way of prevention!

"Do you imagine," says John Birkinbine, president of the Pennsylvania Forestry Association, "that the farmers of any section of the state would fail to hunt out and punish the vandals who would destroy wantonly either a field of wheat or a stack of grain or hay, that represented the growth of but part of a year over a few acres, or that they would hasten to aid in putting out the fire? Yet this same community has undoubtedly seen forest fires follow one another until but few wooded areas have escaped. Its residents can recall numerous instances where many miles of timber were ravaged, the fire continuing for days, with no public protest save against the inconvenience of a smoke-laden atmosphere, and no concerted action towards checking the flames until fences, barns and homes of individuals are threatened."

Calamities of this kind are never single in effects. Then why is nothing done to pevent such destruction? Men don't seem to think about what ought and can be done. They are evidently dead-locked by the fire-king - held as in a dread negation. "The best we can do," say the lumbermen, "is to cut every pine as we go that is over eight inches in diameter, and make the most of the situation."

\section{SERIOUS INJURY TO THE SOIL.}

H. B. Ayers, who is familiar with the condition of all our wood-lands and well posted, estimates "that two tons of dry vegetable growth per acre is the least through which fire will follow. In the forest, I think as much as 100 tors per acre are frequently burned; while the average prairie fires is a consumption of four tons per acre, and of forest fires, ten tons per acre. On this basis over $100,000,000$ tons of dry vegetable material is consumed each year in the forest. The effect of repeated burnings is both logically and practically to reduce a fertile soil to a desert. By combustion, part of the vegetable matter which, decaying, would become a store of vegetable food, is passed as gases into the atmosphere, and blows to other regions. The ashes, a small proportion of the whole, lie on the surface to be leached, mostly into the streams; or, if the soil be open, to a depth from which the tardy new growth cannot recover it. What plant food remains on the surface commonly centers into a growth of weeds and brakes which again 
are burned and dispersed. After this operation has been repeated a few times, nature often ends it by refusing to produce a growth sufficient to support a fire. Where sandy lands cleared by fire are farmed, the first crops are commonly good, but decrease from year to year, until un profitable. Rocks, covered by a light soil, when burned over are laid bare and commonly remain so. The lands held by the government probably suffer the most loss. Marketable property, as well as resources, is destroyed by fire. The census of 1880 reports losses by forest fires to the amount of $\$ 25,462,250$."

\section{REMEDIAL MEASURES.}

The following is the draft of a bill, applicable to all the states, furnished by Prof. B. E. Fernow and approved by Hon. J. Sterling Morton, secretary of agriculture:

\section{AN ACT FOR THE PROTECTION OF FOREST PROPERTY.}

\section{FOREST COMMISSIONER.}

Section 1. Creates a forest commissioner, whose office may be either an enlargement of some existing office, or much better, a separate one, with adequate compensation in either case, to be appointed by and reporting directly to the governor.

Sec. 2. Prescribe the duties of the forest commissioner, namely, to organize, supervise, and be responsible under the provisions of this act for the protection of forest property in the state against fire. In addition he is to collect statistics and other information regarding the forest areas in the state, and the commerce of wood and allied interests; especially'such information as will explain the distribution, value, condition and ownership of the woodland. This information and the results of the operation of this act, together with suggestions for further legislative action to be embodied in annual reports.

Sec. 3. Provides for the giving of a bond by the forest commissioner for the faithful performance of his duties, and fixes fines for such neglect in performing the duties of the office as may be proven, and explains the manner of imposing and collecting such fines.

\section{ORGANIZATION OF FIRE SERVICE.}

Sec. 4. Constitutes the selectmen of towns, or the sheriff's deputies, constables, supervisors, or similar officers, as fire wardens. If preferred, special fire commissioners may be appointed by the forest commissioner with the advice of county commissioners, or both methods of providing fire wardens may be employed together. The towns are to be divided into fire districts, the number and boundaries to be governed by the exigencies in each case, and each district to be under the charge and oversight of one district fire warden. One of these should be designated as town fire warden, to take command in case of large conflagrations. The town fire warden and at least fifty per cent of the district fire wardens should be property owners in the county, unless a sufficient number of such cannot 
be found or a considerable number refuse to serve. A description of each district and the name of the fire warden thereof are to be recorded with the forest commissioner and the town clerk or similar officer.

Sec. 5. Provides for employment of special fire patrols in unorganized places in any county and during dangerous seasons, especially in lumbering districts, and for coöperation of forest owners. Wherever unorganized places exist in a county or so far disiant from settlements as to make discovery of fires and speedy arrival of regular fire wardens impossible, or wherever the forest owners whose property is specially endangered require, the forest commissioner may annually appoint special fire patrols, to be paid at daily rates, the owner paying one-half the expense and the state the other half, such patrols to be under the regulations of this law, and to report to the nearest fire wardens. The manner of appointment and the matter of compensation and duties are to be formulated by the forest commissioner.

Sec. 6. Defines the powers and duties of fire wardens; to take measures necessary for the control and extinction of fires; to post notices of regulations provided in this law and furnished by the forest commissioner; to ascertain the causes of fires and prepare evidence in case of suits; to report each fire at once to the forest commissioner on blanks furnished, giving area burned over, damage, owuer, probable origin, measures adoptea, and cost of extinguishing; to have authority to call upon any persons in their district for assistance, such persons to receive compensation, as determined by the selectmen or county commissioners, at the rate of not to exceed fifteen cents per hour, and to be paid by the town or county upon certification by the forest commissioner.

Persons refusing, when not excused, to assist, or to comply with orders, shall forfeit the sum of $\$ 10$, the same to be recovered in an action for debt in the name and to the use of the town or county, or for the fire protection fund.

Fire wardens shall be paid $\$ 10$ a year as a retainer, besides days' wages at the same rates as sheriffs or similar officers for as many days as they are actually on duty, and shall be responsible for prompt extinction of fires and be amenable to law for neglect of duty. The district fire warden shall call on the town fire warden in case of inability to control fires, and the town fire warden shall have sheriff's power to enlist assistance, as provided in case of a mob.

\section{FIRE INDEMNITY FUND.}

Sec. 7. Provides for the creation of a fire indemnity fund, each county to pay into the state treasury $\$ 1$ for each acre burnt over each year, the special fund so constituted to be applied in the maintenance of the system provided by this act and for the payment of damages to those whose forest property has been burned without neglect on their own part or on that of their agents.

The burned areas shall be ascertained by the county surveyor and shall be checked from the reports of fire wardens by the forest commissioner. All fines collected under the provisions of this law shall also accrue to the fire fund. 
JURISDICTION AND LEGAL REMEDIES.

Sec. 8. Establishes jurisdiction and legal proceedings in case of prosecution of incendiaries and adjustment of damages, and imposes upon every district judge the duty, in charging the grand juries of his district, to call special attention to the penal provisions of this act and of any similar acts providing for offenses against forest property.

Sec. 9. Charges the forest commissioner to issue and publish, by posters and otherwise, reasonable regulations regarding the use of fires, such regulations to contain special consideration of campers, hunters, lumbermen, settlers, colliers, turpentine men, railroads, etc., and to be approved by the governor.

Sec. 10. Makes it a misdemeanor to disobey the posted regulations of the forest commissioner, or to destroy posters, or to originate fires by neglect of the same; provides that the prosecution shall be prepared by the forest commissioner; and imposes fines and imprisonment in addition to dumages. Fines should be double the actual damages; one-half to go to the fire fund, one-half to the person damaged.

Sec. 11. Makes it a criminal act, subject to indictment, to willfully set fires, and imposes fine and imprisonment.

Sec. 12. Any person whose forest property is damaged by fire not, originated by his own neglect, and who is able to prove neglect on the part of the fire warden, may call upon the forest commissioner for award of damages, whereupon the forest commissioner, in conjunction with the county authorities, shall investigate the case and shall refer his findings to the judicial officer of the district, who shall charge the grand jury to indict any offender against this act and adjudge any neglectful fire warden, or other officer, or any person refusing to act upon order of the fire warden.

Any neglect on the part of the forest commissioner to investigate and fine in each case within one year from the appeal of the owner shall be followed by dismissal, unless reasonable cause for failure be shown.

\section{LIABILITY OF RAILROADS.}

Sec. 13. Charges railroad companies to keep their right of way free from inflammable material by burning, under proper care, before certain dates to be established by the forest commissioner. Failure to do so upon notification by the commissioner shall be followed by the arrest of the superintendent of the section, who shall be liable prima facie to procedure under section 10.

Sec. 14. Provides for the use of spark arresters, failure to comply with this provision to be followed by arrest of the superintendent or other officer in charge of the motive power and by procedure under section 10.

Sec. 15. Fires originating from the tracks of a railroad company shall be prima facie evidence of neglect on the part of the company, and the engineer and fireman shall be liable to arrest and procedure under section 10.

Sec. 16. In all cases where fire originates through neglect of a railroad company or its agents, both the company and its officers shall be liable for damages under the provisions of section 12 . 
Sec. 17. Establishes special liabilities for damage by fires in case of railroads under construction.

\section{FIRE INSURANCE AND STOCK LAWS.}

Sec. 18. Provides for the incorporation of forest fire insurance companies. It states where cattle are allowed to roam, provisions to stop this practice should be enacted.

\section{FURTHER DUTIES OF FOREST COMMISSIONERS.}

Sec. 19. Defines minor duties of forest commissioners, namely, to cooperate with superintendents of schools and other educational institutions in awakening an interest in behalf of forestry and rational forest use.

Sec. 20. Provides for salary and other expenses of the office of forest commissioner, which should be liberal in proportion to the responsibility of the office.

Sec. 21. Repeals all acts and parts of acts inconsistent with provisions of this act.

$$
\text { "WOODMAN, SPARE THAT TREE!" }
$$

Hear this wail from Michigan:

"Not very many years ago," said Manager Stevens, of the Cranberry iumber Company, "if the prediction had been made that lumber would have been shipped into Grand Haven, Muskegon and other east shore Lake Michigan towns within the life-time of the old prophet, thestatement would have been received as idle talk. Much wilder would that statement appear as applied to the Saginaws. But already considerable lumber is being shipped to the lower Lake Michigan towns, and what is being done for Muskegon, will shortly be done for Saginaw-her yards will be stocked from outside sources."

If Michigan had done forty years ago what it is not yet too late for Minnesota to do with profitable results, provided for the restoration of the forests from which matured trees had been cut, she would not now be timberless, and her great lumber interest would not be a grinning skeleton! A proper administration of the forests of Michigan would have given her a perpetual succession of matured forests, and her lumber business would have been without end. Under that system Michigan would not have made so much lumber in any one year as now stands on her records, but in a hundred years she would have produced infinitely more. She might have had a good square meal of lumber every day of her life, but she elected to have a feast for a few years and a famine to all eternity! That state now sees the error of her ways when it is everlastingly too late; will not Minnesota see hers while salvation is yet possible?

The remaining pine lands of the state are now in or are rapidly passing into the hands of one syndicate of inordinately rich men, made rich by our vast natural wealth of forest that they were permitted to appropriate and devastate in gratification of their insatiate greed. This "Weyerhauser Syndicate," as it is called, now owns an absolutely controlling interest in all the available pine timber in the state, and with its holdings in Wisconsin 
is the largest owner of pine lands in the world. The people of the state, of the great treeless region that stretches out to the west and north, will soon be bound hand and foot by this many-tentacled pine-land devil-fish. Whatever it may elect to charge for lumber, the puny mortals that crawl beneath its large arms will be compelled to pay, with the result that untold, unrighteous millions will fall into its coffers.-Farm, Stock and Home.

\section{UTILIZING OUR TVOODS.}

The Forestry Association has never put a thing in the way of utilizing our forest products, though we have been charged with so doing. What we ask for is a wise and prudent use of what nature has provided for us. We want lumbermen and manufacturers to understand our position and credit us as their supporters in all legitimate and honest enterprises dependent on forestry. What we want is this: To improve the forest by cutting, save the "fittest" of the younger trees for future use, and retain the forest floor and forest roof intact for the beneficent purpose of preserving the springs of the water-sheds to our lakes and rivers.

OUR SURPLUS WHITE BIRCH.

In Minnesota are immeasurable quantities of small white birch(Betula papyracia) that spring up with the poplars on the denuded districts and where the fires have raged. The fires have changed the chemical conditions of the soil injuriously, thus placing forest evolution on the retrogressive line; but the divinity inlaid in nature, ever true to her laws, builds there again as best she can, and builds what is adaptable, thus paving the way again from the retrogressive to the progressive, for the oaks and pines and maples to return and bless humanity. But there are lucrative uses for all things. We should make the most of the situation, despite the raids and ruins men have made of the bounties of providence. The great body of our white birches are young, and altogether too thick for healthy forest growth. If we do not thin them out, nature will. Why not aid in the fitting process for profit? To cut so small trees for lumber would be useless. There are calls for them on profitable lines.

An enterprising firm in Alpena, Mich., manufactures 15,000,000 thread spools from the young white birch for the Eastern factories. The material, it is said, is getting scarce in that state. That kind of wood also is profitably converted into spring bobbins, knife trays, medicine boxes and the like. Why not appropriate such surplus material in our woodlands before the fires get in or nature's art of thinning out destroys it?

\section{OUR OSIERS FOR WILLOW-WARE.}

The Red Osier (Salix purpurea), largely grown in our country, is recommended, but it does not seem to thrive as well with us as in Europe. The "fittest" has not yet been fully tested for safe ventures.

It is claimed by men engaged in the business that the Belgian and French varieties thrive best on high ground. It is estimated that during even the first three years the properly cultivated willows, under ordinary circumstances, will produce from 3,000 to 5,000 pounds of peeled willows ready for market, the price of which is ten cents per pound, wholesale. 
It requires 65,000 twelve-inch cuttings per acre, well drained and plowed, sixteen inches deep. Cultivate shallow, and mulch. During the winter cut the rods down close to the ground. Rightly managed, the willow farming will be profitable on that lot for fifteen years; then newly plant.

\section{UMBRELLA AND WALKING STICKS.}

A trade in the above commodities is of great proportions; and whoever engages in the business of raising them from the thickets will find it in the near future a paying industry. We can grow them from seed sown broadcast on our properly managed prairie or woodland soils. Suitable for the market are our Red and Jack pines, spruces, birches, elms, maples, ashes, oaks, box elders, diamond willows, etc. The value of the sticks can be enhanced by artifices in producing oddities for heads and handles. They can be cut in a few years.

Presenting this industry as a lucrative one, "Hardwood" says: "America furnishes a great variety of woods and canes for both walking and umbrella sticks, and a number of concerns make a business of collecting and dealing in them, and a large number are exported to Europe, while a much larger number are imported from every quarter of the globe. Millions of young saplings from the forests of the entire United States and Mexico, and canes from the brakes of the South, are consumed annually in the trade."

\section{HOOP-POLES.}

There is no need of advising men who live among our native trees to thin out the clumps of the ashes for hoop-poles. They are doing that and thinning the species out of existence. Say, leave a few, please, that the generation of the twentieth century may credit us with having sense and philanthropy enough to transmit a type of the "fittest." But what a profit any of us could make from our woodlands or prairie acres, were we to raise the ashes thick as they could healthfully grow from broadcast seeding and keeping out the weeds and grasses.

SEEDLINGS FROM THE WOODLANDS.

Nature sows her seeds bountifully, but owing to soil conditions only a few can sprout; where localities are specially favorable success is certain. Why not prepare conditions there and raise plants by carloads from the prairied Northwest? The investment would pay, and at the same time improve our native woods.

\section{MATURE TREES.}

As in the cases just stated in respect to very young trees, the removal of the mature ones should be made to subserve two objects, market profit and forest improvement. As says an American forester:

"True forestry recognizes the forest as a crop to be harvested when ripe, but asks that this crop, requiring decades and even centuries to mature, should receive at least equal consideration with others which demand but a few months to complete their growth. It seeks to have the frugality which encourages the farmer to utilize the straw threshed from his grain evidenced in making use of the tops and limbs of trees felled for timber. 
It realizes no essential difference in the folly of cutting a field of grain when but a part of it is fit for the reaper and denuding an area of forest land of which a portion only is in condition for service. The friends of forestry consider trees as much a gift of the Creator as any other vegetable product; they recognize that being placed here for the use of man, man should use them when matured. It is not the use but the abuse of the forests against which we are arrayed."

\section{SUPPLY AND DEMAND.}

At a meeting of different forestry organizations held in Albany, N. Y., March, 1894, among the other matter-of-fact things presented for serious thought was this, by John W. Wood, a lumber dealer, of Boston, who, after detailing the scarcity of timber on special lines, stated that there are "progressive lumbermen among the friends of the forestry movement"; that such do not "stand to the forests in the light that the potato bug does to the potato plant." He added: "The question for the lumberman to settle is, where is he to find the material on which to continue his business? Wood can be had from the tropics for certain purposes, but it is very expensive. All the mountains of our country have been scoured by men on foot and on horseback who were seeking fresh lumber supplies, and the 'question now is, where is the wood to come from?"

In an address delivered by Col. Platt $\mathrm{B}$. Walker, a prominent lumberman of Minneapolis, at the forestry session of the Horticultural Society, January 11, 1892, he gives this voice of warning: "The destruction of forests in America during the century (especially the last half) is unparalleled in the world's history, both in its extent and in the ferocity of its slaughter. The bulk of the timber which adorned the country over, the Middle states in particular, was consigned to the flames to make way for the plow. This timber comprised a long list of varieties of useful and valuable woods. If the oak, walnut, cherry, ash and other woods which went to the log heap, or into fence rails, were standing to-day in Ohio, Kentucky and Indiana, it would net enough to give a stone mansion to every farmer in those states. Be it said, in extenuation of this almost crime, that its perpetrators were not prophets, and could not see that this world of timber could sver be utilized or would grow into enormous values for domestic as well as export purposes. The destruction of our pine forests has proceeded for the last quarter of a century at a rate that will soon deprive us of a supply of this timber. Eastern Michigan is practically denuded and relies on Canadian timber to run her mills, and the western half will soon be in the same condition, with no outside supply available for her mills. The Southern states have not, as yet, made such fearful inroads on their timber resources, but they are afflicted with the same mania for destroying which has characterized the Northern states. Another generation will complete the destruction of the invaluable timber supply which adorns that section of our coun- 
try. They are offering every possible inducement to secure men and means from an'y part of the world to come and hew down their forests and carry away the proceeds. The difficulty seems to lie in the low valuation placed upon the timber. This, in the nature of things, will continue until we are compelled to resort to timber culture, as they have in Europe, for our supply."

Prof. B. E. Fernow, chief of the forestry division, says: "That it is now time to consider the question of future supplies may now be inferred from the following rough estimate, the only kind possible with our present statistical knowledge: "We use in the United States, according to estimates based upon census and other figures, over $22,000,000,000$ cubic feet of wood annually. Of this enormous amount (about 350 cubic feet per capita) over $4,000,000,000$ cubic feet of the best timber are made into lumber (between $30,000,000,000$ and $40,000,000,000$ feet board measure); railroad construction requires about 500,000,000 cubic feet; and fencing takes an equal amount; but by far the largest consumption is for firewood. An uncertain amount is burned up every year in forest fires, which rage over the western mountain country especially, and which swell the total consumption, probably, to beyond 25,000,000,000 cubic feet annually. During the last three decades an increase of about thirty per cent in consumption for each decade is indicated. The area covered with wood growth is less than $500,000,000$ acres. If all the land area not known to be treeless or in farms were under forest, the acreage would not exceed $850,000,000,000$ acres, but the lower figure is probably more nearly correct."

\section{DEMAND FOR SPRUCE.}

To supply the raw material for the 1,250 tons of ground wooa puip, chemical pulp and sulphide pulp, now used in the United States, requires about 2,200 cords of spruce each day. Every twelve months 100,000 acres of forest is cleared of its mature spruce, or of such as can be converted into pulp. Nearly $1,700,000$ feet of spruce logs are used up for this purpose every 24 hours, or upwards of $500,000,000$ feet per annum. For a safe estimate, not less than 15 per cent should be added to this consumption at each year of its repeated manufacture, to furnish a supply adequate to the demand.

\section{INCREASE OF THE BUSINESS.}

During the last ten years the business has increased 500 per cent. Five years ago the ground product was estimated at $\$ 12,375,000$. Its uses are constantly augmenting. It continues to be the great staple of paper manufacture. Already it is transformed into wheels, horseshces, waterpipes, pails, tubs, flower-pots, domestic utensils and furniture of every description, carriage bodies, building ornamentations, protective armor to torpedo rams, bullets for rifle use, boots and shoes, bed-clothes, apparel for the body, food products, alcohol, and even human teeth, and how many 
more uses the near future will develop we cannot now enumerate. Spruce wood, not constructed into pulp, constitutes sounding-boards of most of our musical instruments, and when free from knots and shakiness brings an enormous price for this purpose.

\section{ALARM OF THE MANUFACTURERS.}

Should not an industry so vast and important be studiously guarded by legislation? We are so fast exhausting this providential source of art and wealth and comfort, that pulp manufacturers, in the East especially, are alarmed and are looking about experimentally to find, if possible, material to take the place of spruce. It may be discovered. But this anticipation, illy founded as yet, should not deter vigilant action to spare this tree from extinction. If a substitute be found, the commercial value of the spruce cannot lessen on other lines of manufacture.

\section{Tree Planting in the Red River Valley.}

Many residents of the Red River Valley have had much difficulty in raising planted trees greatly to their discouragement. When trees naturally grow along some of the rivers there, it should inspire them with hope. Evidently where failure occurs, it is due to improper management. Of course if their purchased trees are defective, and they are apt to be so when purchased of unscrupulous tree peddlers, or damaged by exposure to sun heat while planting, or by shabby planting or by neglect to cultivate after planting, the trees will die, and that speedily. The following extract from a paper by Rev. O. A. Th. Solem, read at the forestry session of the Horticultural Society, January 11, 1894, gives a sure index of success in that valley under right management. Halstad, where this forester lives, is located in Norman county, 471/2 degrees north latitude.

"Six years ago I made an attempt to plant evergreens, but was careful not to procure trees from the canvassing agents. I gave my order to a responsible and highly recommended nursery. My trial order gave entire satisfaction, and as a result I now have several thousand trees of different varieties. Last year I had the pleasure of distributing a goodly number of these trees among my friends.

"I now have sixteen different varieties of evergreens, ranging from two inches to five feet in height, a majority of which seem to be thrifty and doing well. Scotch pine grows very raidily. 'Colorado Blue Spruce' grows quite slow, but pleases and engages my attention the most. It is my intention to secure as many as possible of this fancied variety. I have quite a number of this variety from seed. Of deciduous trees, I have a vast assortment, such as elm, American linden, American larch, red cherry, European birch, etc. American larch grows very rapid here. Red cherry and European birch remain unmolested as yet, but cannot give any definite opinion as to their hardiness this being the first winter of my experience with this variety. 
"I planted a portion of black locust seed last spring. These grew to a height of about eighteen inches, and have not as yet been injured by frosts. I noticed that a few of these black locust seedlings had been slightly nipped by the frost, while others remained entirely untouched.

"Black walnut trees planted four years ago were slightly touched by frost the first spring after being planted; since that have remained thrifty and uninjured.

"The interest taken in tree culture increases each year, and my attention has been called to the fact that more trees were planted last spring than at any other time in the history of the Red River Valley; but I cannot refrain from expressing regret in the face of the fact that cottonwood trees are - planted in excess of any other kind, well knowing from personal experience and observation that the cottonwood is the least adapted to the soil and climate of this country."

\section{LosiT $\$ 200,000$ !}

In his practical lecture, Feb. 23, before the Farmers' Institute held in Minneapolis, Hon. Geo. T. Powell, speaking on "Fertility of Soll," dwelt with great earnestness upon the absolute necessity of planting forest trees for the purpose of enriching the soil with the fertilizing properties of decayed vegetation, and with moisture, which the farmer must have for his plants or fail of a crop. He also emphasized the commercial value of trees, constantly rising in price all over the country, owing to the almost universal scarcity; and illustrated his statement with an incident that occurred in Indiana:

In early years when the farm was developing to be something, the farmer referred to, planted four young black walnuts. Under proper treatment they grew well and at last became magnificent trees, vast and clean in trunk and limbs, bearing delicious nuts every year. About this time a lumber-dealing gentleman, having observed them, one day offered the owner fifty dollars each, if he would cut them down for market. Though hard pressed for money, the farmer declined the offer. A few hours after, returning home, the farmer said:

"Wife, I have lost $\$ 200,000$ to-day."

"How can that be," she laughed, "when you never had so much in your life?"

Here he related the offer of the lumberman, adding, "If when I planted those four wainuts, I had been sensible enough to have planted four thousand such, don't you see I would to-day be worth $\$ 200,000$ ?" 


\section{FOREST CHEMISTRY.}

\section{BASIC ELEMENTS.}

It is a well known fact that the air is composed mainly of three basic elements-oxygen, carbon and nitrogen. Oxygen is the support of combustion and respiration. For this reason vast quantities are needed, and providentially it is the most abundant element of the earth, and the most widely distributed. It forms from forty-four to forty-eight per cent of the solid crust of the earth, eight-ninths of water and about one-afth of the air.

\section{MECIANICAL OPERATIONS.}

The basis of the soil is mineral, rock. The coarse pebbles or gravel, composed for the most part of quartz, lime and feldspar, were once solid rock, and so the sands and clays. What has crumbled the crystalline rock into such shapes? One of the agencies is water, that sinks into the crevices and porous constituency of the rock, and by its expansion in freezing and reactionary contraction, pry the huge pieces apart and break them asunder. All this while carbonic acid gas and oxygen in water are "Time's busy fingers" wearing away the hardest granites. The roots of the great trees penetrate into the cracks, following wherever the dust has crept in, and by their growth dislocate their imprisoned walls. The glaciers carry great stones in masses of ice, grinding slow, but grinding fine, down over the mountain slopes and over the valleys of the mountainous countries, forming vast strata of clay, digging out monstrous hollows in the softer rock along the crystalline sides and bottoms for subsequent lakelets to stay in.

Gerkie, in his Text Book of Geology, page 339, thus outlines tho mixed soil-making process: "On the level surface, the weathered crust may remain with comparatively little rearrangement until plants take root in it, and by their decay supply organic matter to the decomposed layer which eventually becomes what we term 'vegetable soil.' Animals also furnish a smaller proportion of organic ingredients. Though the character of the soil depends primarily upon the nature of the rock out of which it has been formed, its fertility arises in no small measure from the commingling of decayed animal and vegetable matter with decomposed rock."

\section{CAR3ON DIOXIDE.}

In combination with bases, carbon occurs in enormous quantities, particularly in ordinary limestone, chalk, marble, calc-spar, etc. By the "chemistry of nature" it is crumbled, oxydized, enters a gaseous state, and 
forms itself into a compound of carbon and oxygen, carbon dioxide, commonly known as carbonic acid gas. This gas is found more or less in all natural waters. Mineral waters contain it in large quantities. It issues from the earth, particularly in the region of volcanoes. From our fires, from our lungs, from the lungs of all animals, from the processes of alcoholic fermentation and of decay of vegetable and animal matter, from even the sugar in our ripened fruits as they fall to earth and undergo spontaneous changes, is evolved this gas, constantly flooding the air we breathe, and yet its relative quantity in the air is small, about three parts in ten thousand.

\section{NOT A POISON.}

Carbon dioxide is not a deadly poison, as reputed of it. The reason why it is destructive to life, is because it does not contain the oxygen necessary for breathing processes. One dies, then, by suffocation, as in drowning in water. Wherever it is in excess-oxygen not being in proportional balance-there is danger. Air in which a candle will not burn is not fit to breathe.

\section{THE CENTRAL ELEMENT.}

Yet this gas is the central element of organic nature. "There is not a living thing," says Ira Kemsen, professor of chemistry in the Johns Hopkins University, "from the minutest microscopic animal to the mammoth, from the moss to the giant tree, which does not contain this element as an essential constituent."

The plants root themselves in the mineral kingdom and evolve its elements to finer conditions. The food of animals largely comes from plants. The food of plants largely comes from carbon dioxide of the air. The leaves and other tissues of plants have the power to decompose the carbon dioxide with the aid of the electric rays of the sun, appropriating the carbon and giving the oxygen over to the animal kingdom. Thus each kingdom "lives and thrives on what the other rejects." Under this beneficent balance of nature the composition of the air is kept mainly constant.

"When the life process stops in the animal or plant, decomposition begins, and the final result of this, under ordinary circumstances, is the conversion of the carbon into the dioxide."

To what extent this retrogressive action goes it is difficult to determine. The inference is that in unbalanced states of the gases, a certain percentage falls back into crystallization to be taken up again by the plants. For even centuries we may locally unbalance nature, as in excessive deforestation, but we cannot do it with impunity. Nature severely punishes the spoiler. Man robs himself. Prof. Houston well says (Outlines of Forestry, page 145) that in many cases the denudation of the soil produces a permanent disturbance of nature, "from the inability of such section of the country to sustain plant life."

\section{STORED ENERGY.}

Dana, in his Manual of Geology, page 323, argues, "That the carbon which is now coal, and was once in plants of different kinds, has come 
from the atmosphere, and, therefore, that the atmosphere contains less carbonic acid than it did at the beginning of the carboniferous period, by the amount stowed away in the coal of the globe."

This storage of energy is going on to-day, although not in the same degree. "As long as life continues," says Kemsen, "plants and animals are storehouses of energy." The chemical process of setting free the heat evolves a power of work. Thus the burning of the coal drives the engine, cooks our food and warms our rooms. Oxidation or decomposition of carbon dioxide is an evolution of latent heat not always perceptible or appreciable, but sufficient in its silent operations to run the machinery of plant and animal life. Think of the vast storage of these elements in our growing woods, providentially reserved for our use.

\section{WOODLAND LATENT WARMTH.}

All plant life is dependent on the decomposition of carbon dioxide and water, taking place constantly on the face of the earth. In the storage process or in its decomposition, heat, originally wrought by the action of the sun, is the result, which work is, no doubt, an unseen factor in plant growth. Humboldt claims "that trees are conductors of heat, and convey the warmth of the atmosphere to the earth when the earth is colder than the air and most needs it." And so the reverse. Trees being the storage of heat, they radiate it in winter. The foliage in summer being a shield against the hot sun, and the evaporation underneath being an expanding process, there is a reaction to cool down. The forest, then, is an equalizer of temperature in winter and summer.

\section{WATER.}

Water acts as a solvent, and is essential in the chemical processes herein mentioned. It is composed of one volume of oxygen to two of hydrogen. The ratio by weight of equal volumes of hydrogen and oxygen is 1:15.96. Water is a very stable compound. Without it there could be no life sustained upon the earth. Hydrogen is contained in combination with carbon and oxygen or with carbon, oxygen and nitrogen, and occurs "in most substances of animal and vegetable origin, such as the various kinds of wood and fruits and the tissues of all animals."

\section{NITROGENOUS ELEMENT.}

Nitrogen is the main constituency of the air. It does not support combustion nor respiration. It is not a poison, but animals would die in it for want of oxygen. Give twenty-one volumes of oxygen and seventy-nine volumes of nitrogen, or by weight twenty-three per cent of oxygen and seventy-seven per cent of nitrogen, and human beings and animals will live in the mixed compound.

Nitrogen, it is said, "dilutes the oxygen." This is an inadequate conception of its use. It is an essential constituent of plants and animals. "The animals get their nitrogenous compounds from the plants, and the plants get theirs partly at least from the soil." When the plants and animals decompose in the soil, by a process known as death, "the nitrogen 
contained in them is gradually converted into salts of nitric acid or nitrates, and if the decomposition takes place in the air, the nitrogen is converted into ammonia."

Prof. Snyder, of our Experiment Station, says: "Nitrogen supplied for plants and crops is the most important factor, economically considered, of all the elements that are necessary for plant food."

\section{HOW PLANTS GET NITROGEN FROM THE AIR.}

Botanists have of late discovered that the little nodules or tubercles on the roots of pines, oaks, willows and many other trees, also on those of leguminous plants, such as the clovers, peas, beans, lupines, etc., so far from being evidences of disease, are root-ganglia, so to speak, developed by a species of bacteria, by which the plant gets its atmospheric nitrogen. Prof. E. W. Allen, assistant director of the office of Experiment Stations, Washington, D. C., applies this important discovery to agriculture, bulletin 16, p. 6: "It is sufficient for practical purposes to know that nitrogen is taken up from the air by the growing plant, directly or indirectly; and that this nitrogen assimilation takes place as a result of the life of bacteria. It, is a peculiar fact that few, if any, root tubercles are formed when leguminous plants are manured with nitrogen; the plants must first hunger for nitrogen before the tubercles are formed, and the presence of tubercles indicate that the plant is taking nitrogen from the air." After showing the necessity of aiding crops by "soil inoculation," a light dressing of soil "in which the kind of plants it is wished to grow have been previously grown," he urges enriching the soil with nitrogenous elements by green manuring of plants producing them, clovers especially. "It will thus be seen that by green manuring with leguminous crops it is possible to manure the soil with nitrogen from the air, a free and inexhaustible source, and thus avoid buying fertilizers containing much nitrogen. This greatly lessens the expense for commercial fertilizers, for nitrogen is the most expensive element the farmer has to buy."

\section{CORRELATION OF AGRICULTURE WITH FORESTRY.}

In the cases cited we learn, in a new light, the delicate correlation of agriculture with forestry. What the intelligent farmer does with the green manure of leguminous plants whose nitrogenous properties they have extracted from the air, nature is constantly doing in her massive forests where the spoiler hath not trod. She manures the forest soil with green and ripened leaves; they form a perfect mulch that economizes the moisture which the trees must have; they oxidate and decay next to the surface soil, whence is evolved the nceded nitrogen for plant growth. Thus the roots by a chemical art that we cannot fathom, take up the primates of the mineral kingdom and transform them into living tissue. If on this progressive line there is yet a deficiency of nitrogen for healthful assimilation, the lower forms of life, bacteria generated by these processes, build gangliobatteries on the famishing roots, and the trees are re-invigorated for woody structure. This chemical operation, whereby pure oxygen is tendered us, prepares a soil for future agriculture, rich in nitrogenous and other nec- 
essary materials for crop growing. The forest is, therefore, the chief source of soil fertility, costing us nothing except care for the trees. In view of its inestimable value Humboldt exclaimed: "How foolishly man destroys the forest cover without any regard for consequences, for thereby they rob themselves of wood and water!"

\section{EVOLUTION OF MOISTURE.}

Chemistry is evolving, this great truth, that the vegetable kingdom is primal in the orders of life; that, while dependent on its co-factors for its existence, in contributing to their support it thereby supports itself. The vegetable kingdom is in fact an essential medium of that universal chemistry, by which, with the sun administering to all in reciprocity, water is evolved. We might as well say that the constituents of the tree are not the tree when properly put together, as to say water is not a part of the tree nor developed by the tree. The gases that make water are in all things, and by the chemical agency of vegetations they are evolved in to the compound called water.

Dr. J. C. Brown, a conservative English writer and acknowledged authority, is bolder in his conclusions than most of his peers. After fairly stating both sides of the question as to whether forests do or do not promote rainfall, he thus strongly fortifies himself:

"TVhile moisture is necessary to make and keep forests, yet the forest in turn conserves and reproduces moisture. These necessary and reciprocal functions should not be arrayed against each other, any more than the centrifugal and centripetal forces of nature, so as to invalidate the fact that forests do retard the rainfall after precipitation and have a general effect on the humidity of the atmosphere and soil."

In further elucidation he suggestively maintains that moisture is aided by the chemical change accompanying vegetation by the combination of oxygen with hydrogen. He says, in his "Forests and Moisture," page 31: "It is not unreasonable to suppose that all the ammonia taken up by the plant may have been decomposed, the nitrogen combining with oxygen, set free by the decomposition of the carbonic acid yielding material for the woody structure and appearing as atmospheric air, and the hydrogen combining with the oxygen and forming water."

Dr. Brown but voices what is impliedly revealed. All chemists agree that among the essential constituents of plant food for structure, when refined and cooked, so to speak, are carbon and nitrogen, and that, through the medium of the plants, the cooking process is performed under the electric rays of the sun that wrest these elements from their crude alliances, and when hydrogen and oxygen are thus set free, they combine and form water.

What is the oxidation of stones and metals down in the ground but a slow burning of oxygen and hydrogen, forming water? From the food we eat and the air we breathe, as with trees, is exhaled and cast out a watery substance, mixed more or less with carbonic acid gas, which when refined again, as described, and exchanged, the animal and vegetable kingdoms are kept in balance. What is it but a water-forming process? As to the amount of 
water thus evolved through the vegetable and animal economics, is yet $\mathrm{nn}$ known. The phenomenon. invites the chemist and the forester. Meanwhile we must content ourselves with this fact, that, given the moisture, we have the forests; given the forests, we have the moisture increased.

When we "learn to heart" what chemistry teaches, that the forest equaljzes the temperature and moisture, and that its roots, leaves and other tissues are nature's great retort in which the gases are distilled, we also learn what an unpardonable crime it is to wantonly destroy the forests.

\section{CLIMATIC.}

\section{COSMIC AND LOCAL FACTORS.}

"The climate of a country," says Humboldt, "is the combination of calorific, aqueous, luminous, ærial, electrical and other phenomena, which fix upon a country a definite meteorological character that may be different from that of another country under the same latitude and with the same geological conditions."

Cosmic factors are based upon certain fixed principles, such as the inclination of the earth's axis to the plane of the ecliptic, which causes thermal variability; the position of the sun in the heavens in its annual swing between the tropics, which contributes to the same result; the circumferential velocity of the earth on its different parallels, lessening proportional to distance from the equator, which produces differences of wind-waves that directly play into meteorological phenomena; the relative position of land to water areas, having unlike heat capacities which, in turn, give direction and force to air and sea-currents; the elevation, the latitude, the configuration of a country, which with other co-factors are directly concerned in the make-up of climate, before whose fiat must we bow and acknowledge our utter weakness.

\section{OUR SITUATION.}

Minnesota extends from north latitude 43 degrees 50 minutes to 49 degrees, and from 89 degrees 29 minutes to 97 degrees 5 minutes west longitude. It is therefore central in the North American continent, midway 
between the Atlantic and Pacific oceans and the Gulf of Mexico and the Arctic ocean. Its average elevation is 1,275 feet above the sea-level, the highest land in the great continental trough between the Gulf of Mexico and Hudson's Bay.

\section{OUR DEPENDENCE.}

Whatever humidity may be projected toward us from the Atlantic and Pacific oceans is largely intercepted and drained by the Alleghanies and Rockies, and such winds come to us dry. The winds from the Gulf of Mexico and the Arctic ocean encounter comparatively slight obstructions as they sweep over the continental trough. When these collide over usif those from the poles are not too dry to dissipate the moisture-precipitation may ensue.

\section{PRECIPITATION FORTUITOUS.}

Our average precipitation is twenty-five inches. Countries near the sea have uniform temperature and therefore more regularity of precipitation, but in a continental climate like ours there are so many agencies at work, precipitation is fortuitous, and yet acts, of course, under irrevocable laws. Were there nothing of a local nature to intercept and tone down our winds, the state and entire plain west of it would have the characteristics of the steppes of Russia, barren, dreary and uninhabitable, save here and there by groups of hungry wolves and clumps of coarse grasses in the burning sands.

\section{THE AIR ON HIGH PLAINS.}

All vast, high plains have dry, hot or cold winds, as illustrated on the central plains of Asia, in the pampas and llanos of South America, in the heaths of Germany and the lands of France. Climatic differences always are related to differences in land elevations. Scientists estimate that an elevation of 350 feet will lower the temperature equal one degree of latitude or seventy geographic miles poleward. In round numbers our average latitude is 46 degrees; our average elevation is 1,275 feet; then, outside of the modifying influences of environment, our average climate corresponds with that of about 50 degrees north latitude on the level of the sea.

\section{OUR MODIFIED CLIMATE.}

But our climate is far from what the rule mathematically warrants. Considering latitude and elevation, we have a luxuriance of flora. Though subject to sudden extremes of heat and cold, and severe storms when they come, even our hottest days have compensative forces, and our coldest are electric and bracing-up to energy. Our nights are cool; our skies clear and so our waters. Taken as a whole, our Northwest climate is superb. To what cause or causes shall we attribute this remarkable feature of Minnesota?

\section{OUR HIGH LANDS.}

In a general sense Minnesota is an undulating plain, but it has its special high lands, hill ranges, clustered knobs, Leaf Mountains, Sawteeth, Mesabi and Giant ranges. Our mountains in the northeast angle of the state rise 
1,600 to 1,800 feet above the sea. The Mesabi Range, north of Lake Superior, attains an altitude of 2,200 feet. These northern elevations are so arranged with respect to each other as to give rise to the different river and lake systems of the state.

CLIMATIC_EFFECTS OF THE MESABI RANGE.

The temperamental and therefore meteorological changes produced by these elevations are very marked. Note especially those of the Mesabi or Iron Range, stretching diagonally over a portion of the state, continuous in the Coteau des Prairies farther on toward the south. According to the ratio of 350 feet elevation to equal one geographic degree, the climate on the highest crest of the Mesabi is about that of southern Labrador.

These highlands are to Minnesota what, on a vaster scale, the Rockies are to the states there environed. They serve the purpose of cooling the moist winds to precipitation that feed our water systems, and thence developing the great forest that has blessed us so much. When the winds from these rain-making batteries in the north, gaining vapor-accessions from the intervening forests and lakes, meet the warmer moist winds of the Gulf of Mexico, from over the western prairies, the product may be rainfall.

\section{Climatic INFLUENCES OF OUR WATER AREA.}

Water absorbs and radiates heat less rapidly than land. Water, therefore, retaining its heat longer, cools the temperature in summer and heightens it in winter. The climatic beneficence arising from this source alone can be better appreciated by noting the quantity and area of our great northern reservoirs, as reported by Maj. W. A. Jones, of the Engineer Corps, U. S., in charge of the reservoirs at the head-waters of the Mississippi, five of which are now completed.

Lake Winnibigoshish: watershed, 1,422 square miles; water surface, 110,206 acres; storage capacity, $344,000,000,000$ gallons.

Leech Lake: watershed, 1,225 square miles; water surface, 110,632 acres; storage capacity, 225,000,000,000 gallons.

Pokegama: watershed, 630 square miles ; storage capacity, $35,000,000,000$ gallons.

Pine River: watershed, 602 square miles; water surface, 15,206 acres; storage capacity, 56,000,000,000 gallons.

Sandy Lake: watershed, 384 square miles; water surface, 7,522 acres; storage capacity, 15,600,000,000 gallons.

A project is on foot to make a reservoir of Red Lake, the largest inland lake of the state, the area of which is estimated at 1,930 square miles.

We have here a vást evaporative surface to supply our forests and agricultural plants, when precipitated, the vapors of which also soften down the raw winds from the highlands, thus making our climate so clean and salubrious.

PRAIRIE AND FORESTAL BREEZES.

In this connection we must consider what a power Lake Superior is in respect to our climate. It belts the northeast part of our state wherever 
the polar winds have direct action. Owing to vacuous air over our heated prairies these winds, moisture-laden, tend to blow inland, precipitating snow, hoar-frost or rain upon our highlands.

Prof. M. W. Harrington, chief of the Weather Bureau at Washington, D. C., says: "As the interior air of the forest is generally cooler, in the warm season, it must be heavier, and the difference of temperature must be often so great that the heavier air will overcome the obstacles to its flow and gradually pour out near the ground. Its place will be taken by the air above, which will settle, and thus there may be set up a forest circulation, exactly corresponding to such a system of winds as is found in land or sea breezes, or may be found over a lake at night."

Thus our water area, together with the vast body of treesco-acting in unison, engender what answers to a sea breeze blowing inland upon the open, heated regions by day, and these land exposures, cooling off quicker at night than the water and forest, send the air waves back in cool refreshment.

\section{DO FORESTS PROMOTE RAINFALL?}

Because a drouth affects a forest, it does not follow that it is not a factor in the promotion of rainfall. We can and do rob the forest of its power to perform its natural functions. Break down its roofy foliage, burn up its leafy floor, and the dry conditions of the forest atmosphere, arising from rapid evaporation, forestall precipitation. This forest unbalance reacts disastrously upon our vast agriculture, whose hungry mouths devour what rain descends, thus largely preventing flowage to the woodlands, and our lakes and rivers recede, trending to a general desert in land and atmosphere.

\section{HUMAN INTERFERENCE.}

The following extract, occurring in "Outlines of Forestry," is from Geikie's "Text Book of Geology," page 471: "Human interference affects meteorological conditions, 1. By removing forests and laying bare to the sun areas which were previously kept cool and damp under trees. * * * 2. By drainage, the effect of this operation being to remove rapidly the discharged rainfall, to raise the temperature of the soil, to lessen the evaporation and thereby to diminish the rainfall."

\section{TESTIMONY OF FORESTERS.}

Collating the facts of history, a majority of scientific foresters maintain that, where great forests have been removed, the rainfall has lessened, and where great forests have been restored, the rainfall has increased. Among the many testimonies are those of eminent professors who have given the matter the closest possible consideration. In his "Report Upon Forestry," 1877, Franklin B. Hough cites the testimony of the distinguished French forester, Prof. Becquerel: "St. Helena-fully forested when discovered in 1502. The introduction of goats and other causes led to the removal of 
its forests. Heavy floods and severe drouths were the result; replanting of forest trees toward the close of 1700 resulted in a more uniform rainiall and its better distribution. Subsequent destruction of the forest have again brought back the original condition of affairs." Prof. Becquerel also tells us that when discovered in 1815, the Island of Ascension "was barren, and so destitute of water that supplies were brought to it from the mainland. The effects of planting trees resulted in increased rainfall."

Prof. Fernow says: "While the forest everywhere does not increase precipitation over its own area, yet a large system of forests over an extensive area will influence the quantity of precipitation over and within this area."

Prof. Harrington cites reports from sixteen meteorological stations in Germany that are always near forests, and 16 like stations near regions without forests, and in most every instance the forest station shows the more rainfall. That at Lintzel was made a date of comparison with a series, being a reforested district. The results are given after the accumulating tree-plantation was five years old, and it was discovered that commencing 1882 and ending 1888 , the percentage of rainfall increased steadily with the extent and height. Experiments were also made on forested and non-forested elevations, covering vast areas, and again the forest led in percentage of rainfall until at the highest point it was nearly double in surplus. After mentioning striking instances in India, Java and Celebes, covering many years of experiment, and allowing a margin of fifty per cent for errors and general rainfall, the professor cautiously adds, "There yet remains an appreciable addition which might be attributed to the growing forest; * * * makes a good presumption that a forest does actually increase the rainfall to an appreciable percentage."

Notwithstanding the accumulating evidences that forests promote rainfall, there are prominent meteorologists in our country, of prudent research, who maintain "there are no evidences to show that forests cause an increase of rainfall." Fortunate for forestry, a world-wide discussion on the subject is evoked, which, on comparing notes, will sooner establish the truth in favor of the trees; and we of the Northwest, where trees are precious, can patiently afford to await developments, confident that the natural coolness of a massive forest condenses atmospheric vapors to precipitation, where other conditions are favorable.

\section{"BLOOD OF THE EARTH."}

Differ as we may, all agree with Prof. Marsh, alluding to trees serving as equalizers of temperature and moisture, that "when man destroys these natural harmonizers of climatic discords, he sacrifices one of the most conservative powers of nature, and does himself great injustice and harm;" and with Cassius M. Clay, of Kentucky, who thus strongly sums up the whole problem: "Forests are the blood of the earth, and in their destruction follows the death of nations."

\section{LAWS OF PRECIPITATION.}

Heat expands moisture; cold condenses it.

Warm air can contain more moisture or vapor than cold air. 
Vapors afloat in the air, when chilled down so as to coalesce, form mist, snow, rain, hail, just as the aerial condition necessitates.

"Mountains act as condensers," says Prof. Tyndall ("Heat as a Mode of Motion," p. 384), "partly by the coldness of their own masses, which they owe to their elevation." Cold wind may produce the same result. If the wind is comparatively warm and laden with moisture, it (the moisture), says Huxley, "will be readily precipitated on exposure to refrigerating influences."

FOREST TEMPERATURE.

Ordinarily the temperature of the air under and just or $r$ a forest is considerably lower than that over an open field; if a vapor-laden wind blows over the forest there is a tendency to precipitation. The trees with their living foliage and carpet of dead leaves, and the extra moisture thus economized, make larger surfaces for heat absorption, preserved in latent state. Being thus shielded, the forest is cooler in summer and warmer in winter than the open field. When the leaves fall in autumn, they are retained on the ground, and over them is spread an even mantle of snow, thus preventing the penetration of frost to any great extent, and rescuing the roots of the trees and any tender flora from injury.

Prof. Tyndall shows that the heat-absorbing power of the air is almost entirely dependent on the presence of water vapor. As the dense forest is more moist than the open field - the former being better shielded and having more wet ground protected from the direct action of the wind-a thicker and wider spread curtain of vapors hangs over the forest, absorbing the sun's heat, intercepting its drying tendencies and reactions to damaging frosts, and so balancing the temperature, the coolness or warmth of the forest air is kept steady and salubrious. A cold wind or chill of the air in a vaporous strata of the forest generally causes precipitation, but not always. The relative conditions of the air determine this. If a cold air wave, charged with moisture, meets a warmer, drier wave, the tendency to precipitation is neutralized, the moisture being then scattered and lifted as vapors to higher altitude.

\section{EVAPORATION.}

Evaporation is the result of the ever active agency of heat and electricity. It is one of the processes by which plants grow. Without it all life would cease upon the earth. It is also a cooling process, self-inductive to precipitation.

It occurs at surfaces. The greater the water or leaf surface (thickness a factor), the greater the rapidity of evaporation.

Cold lessens the capacity of the air to hold vapor; heat increases the capacity.

The drier the, air, the greater is the rapidity of evaporation.

Hence, in the Minnesota climate, the absolute necessity of great water and leaf supply to produce rapid saturation of the aerial fluid for the needed precipitation. 


\section{FORCE OF WINDS.}

This necessity becomes the more apparent when we consider the disastrous effect of our prairie winds. Interesting experiments for the purpose of ascertaining the changes in the rate of evaporation affected by the velocity of the wind were made by Prof. T. Russell, Jr., of the signal service, in 1887. "The results of these experiments show that with the temperature of the air at eighty-four degrees and a relative humidity of fifty per cent, evaporation with the wind blowing at the rate of five miles an hour, was 2.2 times greater than at calm; at ten miles, 3.8; at fifteen miles, 4.9; at twenty miles, 5.7; twenty-five miles, 6.1 ; and at thirty miles per hour the wind would evaporate 6.3 times as much water as a calm atmosphere of the same temperature and humidity. Now, if it is considered that the winds which sweep the western sub-arid and arid plains is from ten to fifteen miles, not rarely attaining a maximum of fifty or more miles, the cause of the aridity is not far to seek and the function of the timber belt or even simple wind-break can be readily appreciated."

Not only does the wind dissipate the water, but it falls upon it with weight, often uncovering our grains in the early spring, beating our plants down and hardening the ground to the great injury of all our vegetations. Smeaton, in his "Philosophical Transactions," gives us some figures as to the force of wind, at special rates, on one square foot of avoirdupois pounds. Thus, the force or weight of a wind blowing at thirty miles an hour is 4.429 pounds; at forty miles an hour, it is 7.873 pounds; at one hundred miles an hour, a hurricane, it is 49.200 pounds per square foot, carrying trees and buildings before it.

\section{VAJ,UE OF ACCUMULATION.}

While the surface exposed determines the amount of evaporation from water courses and reservoirs, it is found that the smaller and slower run loses proportionally more than the larger, illustrating the value and protection of accumulation. A like ratio applies to a forest. If the trees are scattered and far apart, or great gaps obtain by clean-sweep cuttings and fires-as is the resultant condition of our native forests to a large extentthe evaporation is, of course, far greater than where the trees stand close and high.

\section{FOREST EVAPORATION.}

Owing to cover conserving moisture and the wind-breaking power of the trees, the evaporation from the forest is considerably less than from the plants in our gardens and fields. The annual evaporation within a forest is estimated on data of experimentation at about half that of the open field. The forest, therefore, is nature's best economist, steady in action, giving when most needed. Evaporation is one of its distributive forces. "A forest through its leaves," says L. H. Wilcox, "gives far more moisture to the air than the same area covered with water" (about three times more), and in Minnesota it measures among the millions of tons of water.

But plants do not live by water alone, water serves them as a solvent, dissolving and preparing substances in the air and ground for vegetation. 
We must also consider that the water evaporated does not all escape into the air as vapor, but a goodly percentage is reabsorbed by the leaves as soon as breathed out and fitted in the sunned air for wood growth again. To a great extent plants adapt themselves to the amount of water at their disposal.

\section{TRANSPIRATION.}

By transpiration is meant the water consumed in building up the body of the plant; the larger part being returned to the atmosphere during the process of growth. In this operation the quantity of water used is as variable as the quantity of precipitation. "Many considerations enter into the operation-the stage of plant development, nature of its leaves and amount of its foliage, temperature and humidity of the air, intensity of the sunlight, temperature and structure of the soil, etc."

\section{EFFECTS OF OUR NORTHERN FORESTS UPON VEGETATION.}

Note the following facts adverted to by Prof. L. A. Bailey, Jr., of the Agricultural College of Michigan, who, with Professors Warren Upham, E. W. D. Holway and others, assisted our state geologist, Prof. Winchell, in the botanical work of Minnesota in 1886. The expedition, commencing July $17 \mathrm{th}$, was located at the south end of Vermillion Lake, near Tower, at about 48 degrees north latitude, whence they radiated in all directions, mainly between that point and the international boundary. Though their search was systematic, they found "a discouraging paucity of species." Their discoveries were "an illustration of the law, that species decrease with the increase of latitude," and correspondingly, that "the ligneous vegetation simply makes a smaller growth." Summing up the situation, Prof. Bailey says:

"In some respects the flora of this region is anomalous. In most of its features it differs little from that of Central Michigan, six degrees to the southward. This southern cast to the flora finds a ready explanation, however, in the fact that Vermillion Lake is separated from the cooling influences of Lake Superior by a degree of primeval forest. It is probably not so much the character of the winters as that of the summers which influences thə distribution of plants in these latitudes. The snow must afford great protection to all vegetation at this place, and the summers, although short, are warm and the atmosphere is dry."

\section{TREES CREATE CONDITIONS.}

No doubt "the one degree of primeval forest" has something, perhaps much to do in mitigating the severity of the cold winds from Lake Superior. But there is a greater factor involved than a strip of seventy miles of trees. In determining the features of flora in any part of the country, we should first take into our account the prevailing air currents and isotbermal lines which woodlands more or less direct and modify. Writing the editor in this connection, H. B. Ayres aptly says: "The herbaceous flora of Minnesota should be expected to be similar to that of Michigan, because the forests create conditions needed by certain plants. 
The flora of the prairies of northwestern Minnesota differs more from the flora of the wooded northeastern Minnesota than wooded Minnesota differs from wooded New York."

\section{"THE SAHARA OF MINNESOTA."}

They who have taken observation know that vegetation is very meagre and stunted on the north and westerly shore of Lake Superior, having a long and dreary belt several miles wide in some places. This condition is traceable to the cold winds sweeping from the north and northeast over that great body of water. Suppose the forest inland and westward from the desert-like coast were literally destroyed by axe and fire, as is actually portending, what would be the effect upon the climate and upon vegetation in that latitude, and upon the state at large? Imagine the whole forest from Lake Superior to the Red River and north to the international boundary, stretching also hundreds of miles southward-imagine it swept away. Nothing is plainer than that the sources of our river system would be dried up, and all that interesting region would be transformed into a dreary desert--"the Sahara of Minnesota." The winds from the lake, rushing from the frozen north, then uninterrupted-for the forest is goneintensified and infuriated by the desert, would fall upon our agricultural crops farther south with immeasurable ruin. This is not conjectural; it is reasoning from cause to corresponding effect, from what we know of other parts of the world where like furies have been provoked by like deforestation.

SNOW MANTLE.

Prof. Bailey speaks of the benefits of snow upon the flora. Remove the forests there, and the formation of snow is lessened, because the forest humidity is neutralized by the open wind-swept desolation. The forest trees trap the snow, mantling the flora, slowly melting and trickling into the ground, and furnishing the water supply in the summer to our rivers. Nothing could be devised more calamitous to our agricultural and correlative interests than the destruction of the natural forest in the northern part of Minnesota, and nothing should be watched by our legislature with more jealous vigilance than the preservation and culture of dense forests in all that lake and reservoir region.

Here the forest reserve system comes up again for consideration, and will not down, despite the formidable opposition. Climatic conditions, the conservation of our waters, the business interests of the entire state absolutely necessitate its organization.

\section{EFFECTS OF HEATED ROCKS.}

In northern Minnesota, more especially along Rainy Lake river toward the northeast angle of the state, a country once covered with pines and other trees, the fires have at last literally burned them out root and branch, leaving huge piles of bare rocks that heat up in the days of summer and remain warm in the night. Hence, rain clouds sweeping over that desolate surface, formerly condensing in gentle showers, now dry up or pass over 
to more wooded or watered districts. Were that region reclot with hardy vegetation, followed by trees, it would make an appreciable difference in moistening the air and increasing the precipitation.

\section{OUR FOREST ISOTHERM.}

Several years ago, when the forest was less disheveled by axe and fire, it was not uncommon when the temperature indicated five degrees above zero in St. Paul, at the same time the thermometer registered twenty-five degrees below zero, one hundred and twenty miles west on the treeless prairie. It is wonderful what a difference this forest makes in the temperature of Minnesota. The isotherm, or line of equal heat, of five degrees above zero in mid-winter, does not run east and west, as it should under equal conditions. "It commences," says Prof. D. R. McGinnis, "about twenty-five miles northeast of Duluth on the shores of Lake Superior, follows down the lake shore to Duluth; from there, instead of going west, it strikes directly south, and passes a little southeast, possibly twenty miles east of St. Paul, and on to the southern line of the state, and thence through northwestern Iowa."

\section{OUR GREAT WIND-BREAK.}

Everybody who has taken any observation knows that every small body of timber walling up against our strong winds, shows marked results in its influence upon crops. But slight protection makes a palpable difference. The French gardeners understand this; they build tight fences some six feet high to protect their plants against a cold wind that comes down from the Alps, along the Mediterranean. Such a fence will protect the gardens situated a hundred miles to the north of Marseilles.

"According to Becquerel, a simple hedge of six feet in height will give protection to plants a distance of seventy feet, and, according to Hardy, a belt of trees averaging three hundred feet will defend vegetation almost entirely against the action of the wind. Another authority finds for every foot in height, one rod in distance protected." If an ordinary wind-break on the prairie is so efficacious, what must it be on the scale of a great natural forest? and what should so concern us as its preservation?

\section{DEFORESTATION AND CYCLONES.}

The question is of ten raised whether cyclones, involving hailstorms especially, have any connection with the unforested condition of the country. No positive answer as yet has come from the experimentation of the scientists. There are certain cosmic influences at work, lying as yet beyond our analysis. No doubt the configuration of a country, its altitude, its distance from the pulses of the ocean and thence its peculiar atmospheric condition, play a direct part in such phenomena; but is not a forest, or rather the want of a forest, a factor concerned in the solution of the problem? Observations in various parts of the world confirm such a conclusion. 


\section{HOW HAILSTONES ARE FORMED.}

Judging from the mechanism of hailstones, they rotate around a vertical axis. They are composed of alternate layers of ice and snow laid over each other like the concentric rings of an onion. If the whirling motion be between contiguous rain and snow clouds, it would carry the rain in to the snow particles, dusting it and freezing it into hail. There are numerous coatings of ice and snow, indicating a continuous circling of the wind from rain-making into hail, snow and ice-making clouds. If the whirl around a vertical axis dips the water particles in and out of different strata of cloud temperature, warm rain into freezing, snowy air and back into warm air for forming another rain-circle around the icy ball, and so round and round, the products are hailstones, small or large according to the number of times the dipping process has occurred.

Hailstorms are, therefore, cyclonic, of ten moving at the rate of forty to fifty or more miles an hour. They drive on out of the hail-manufacturing belt with terrible fury upon everything they touch.

\section{PREMONITIONS.}

These disasters occur on the open plains and prairies. They are most frequent in summer, following excessively hot days. They are generally preceded by layers of daris gray clouds, moving in angry whirls, accompanied by great electric disturbances of heavy lightning and thunder.

In his elaborate report of $187 \%$, Franklin B. Hough, then acting as chief of the forestry division under the agricultural commissioner, thus credits (page 299) the forest as a

\section{NEUTRALIZER OF HAILSTORMS:}

"It is attested by M. Becquerel, from numerous observations inade in France, that hailstorms become more frequent as woodlands are cleared away, and that although such storms may occasionally pass through a forest of small extent, they will sometimes change to rain over a woodland, and again to hail beyond; but oftener they will turn aside or divide as they come to a large wooded area. This may be accounted for from the fact that the moist air that hangs over a woodland from the evaporation.of the leaves becomes a conductor of electricity, and thus lessens the effect of the storms."

\section{HAILSTORMS MOVE IN ZONES.}

M. Baille, in his "Zones des Orages a'Grele," avers that "zones in hailstorms in France are profoundly modified by local causes, appearing with severity in some districts, and leaving others intact. They have a preference, so to speak, for certain parts of a country, visiting it often, and produeing similar effects, observing therein a singular periodicity, returning at intervals of a certain number of days and hours for a series of years, so that the periods of two bad years are separated by periods of good years. When they come they seldom come singly." The careful observer may have noticed similar phenomena in our own country, that hailstorms seem 
to move in zones, and are attended with a "peculiar periodicity." The remedy is simple and within our power to apply without recourse to the legislature for special appropriations to relieve the sufferers who have lost their crops by hailstorms. Build up long and wide belts of trees in the storm zone so as to divide them, or at least weaken their force of destruction.

GENERAL TREND OF OUR WINDS.

Warning against desert conditions arising from forest destruction, Prof. W. M. Hayes, of the Experiment Station, St. Anthony Park, demonstrates by "the lay of the land" that, while our principal winds in the continental trough from the northwest and southwest collide into confusion, their general trend is eastward as resultant of their combined force, and find their "escape across the lakes and down the St. Lawrence river to the ocean. That there is something of such a resultant wind is shown by the fact krought out by meteorologists, that the most cyclonic storms of this valley pass from the west toward the northeast, having, as some one has said, their focal center in the vicinity of Iceland. The flowing of this air toward the eastward carries most of the moisture to the region east of the Mississippi, there giving up enough moisture to have fostered the primitive forests with which all that region was covered. The moist air flowing away from the elevated plain of the West, left that region supplied with air largely from the northwest and southwest. This air, not containing a great amount of the moistwre, is warmed up and made to absorb rather than precipitate moisture; hence the low humidity of the air, the small rainfall and the consequent absence of trees on the plains and prairies."

THE AFIIAL BATTLE GROUND.

Minnesota being the average highest land in the continental trough, the winds from the gulf meeting those of the cooler northwest are here naturally cooled down to precipitation when the air is sufficiently saturated with moisture: These meteorological forces, together with those of our prairies, highlands, lakes and forests especially, make Minnesota the midcontinental battle ground of the winds, the lower strata of which are whirled in various directions, just as local conditions necessitate, while the strata above the trees and hills are left freer to sweep eastward. Owing to environment, evolving temperamental changes, the collision of the lower strata of winds educe fogs, clouds and showers.

FORESTING THE GREAT PLAINS.

Westward toward the Rockies, known as the Great Plains, there is, comparatively, a scarcity of fogs, clouds and dews, and therefore, diminutive precipitation. This is mainly due to the intense equilibrium of sun-heat in that region. Hence the southwest winds of summer, blowing over those hot plains, falling alike on the Minnesota prairies, are ruinous, sometimes blighting all before them. And such winds will continue to bring drouth and agricultural disaster so long as the plains are treeless. 
Nothing awakens such a dissatisfaction of the country as these merciless winds-simoons in summer, blizzards in winter. The only alternative is, by the aid of irrigation, to reforest the plains by dense wind-breaks; actual forests on a scale of vastness. But it never will be done until the national government takes the responsibility. By irrigated forestry on the Great Plains, protecting and enriching the farms there, bringing like blessings to Minnesota, the intense burn and reactionary chill will be broken up, causing climatic variability and more certainty of precipitation with assurances of successful crops. Adverting to these meteorological changes, consequent upon diversified environment, Prof. F. B. Hough, in his "Elements of Forestry," p. 16, says:

"The air in contact with these heated portions expands, and becoming lighter, rises on the air from the surrounding spaces coming in to supply its place. An upward current is thus formed, and the air rising and cooling comes to the dew point, and the moisture becomes visible as cloud. A column of smoke from a burning clearing, will sometimes thus form a cloud, and may cause rain. (In such a case may not the rain be largely resultant of the burning of oxygen and hydrogen, dropping in water?) A country interspersed with groves of trees presents contrasts in heating tendencies favorable to these upward currents of air."

\section{OUR DUTY.}

Our duty is plain, that we must augment the diversity of our environment by tree and soil culture; that we must haste to retain our water systems by the agency of native forestry, and forestry by the agency of our water systems; that we must reforest our highlands, which are unfit for agriculture, where axes and fires have made havoc, else follow the sequences of neglect-the detritus of those highlands, damaging floods reacting into more damaging drouths, and thence desert conditions to the ruin of all that makes a state.

\section{SANITARY.}

\section{VOICE OF THE TREE.}

Voicing the tree as if it were an intelligent being, Elizur Wright says:

"Let me just whisper in your ear, my kind friend, that what is our food is your poison. Don't take that on my authority. Go to your chemist, ask him what would be the effect of clapping a bell-glass over Boston. Hewill probably tell you that trees would do something toward keeping the human inhabitants from smothering in the poisonous gas of their own breath; but they, not being able to consume their favorite food as fast as produced by 250,000 people (not to speak of horses and furnaces), the people and their 
horses, cats and dogs would soon choke and die. Without the bell-glass the winds waft away the poisonous gas which feeds the forests. Where does it go to? Why does it not come back again to plague you? What becomes of it? Ask your botanists, your chemists, all the people who have been studying the nature of things since Joseph Priestly discovered what air is made of more than one hundred years ago. See if they will not tell you that animals could never have lived and cannot live long on this earth without forests to purify the air. You may ask the historians, too, if great nations have not decayed and become puny and degraded because they made broad and fertile valleys bare of forests."

\section{WATER CONTAMINATION.}

The picture of the real is not overdrawn when it is said that the ruin of our forests breeds the pestilence that ruins the city. Where the water flow of our rivers is kept up-and only large, dense forests will do thisthey wash away the filth of the towns through which they flow, and every new swift current brings them the very elixir of life. Destroy the forests that head the rivers, and they sink lower and lower, and in the hot, dry season they sluggishly float down to us an immeasurable amount of unsanitary dregs, and the people suffer and die. Such river water is liable to contaminate that of our wells, and what an offensive stench arises from it! It is then full of wigglers, microbes, and poisons innumerable. What is the primal cause of these miseries? Simply we have unbalanced nature by imprudently, avariciously, unpardonably slaying the forests where the pure springs would otherwise flow to us with healing in every wave.

Prof. J. T. Rothrock, the official head of the forestry movement in Pennsylvania, says: "Fresh-flowing water which maintains a constant level is in a condition of the least danger to the health of a community. Frequent stages of high water, followed by as frequent periods of low water are a constant danger. It is under such conditions that malarial complications are most frequent. It is clear that we have reached a period when intelligent legislation will be required to avert threatened evils."

\section{CEMETERIES OF NATIONS.}

Whence the cholera and other plagues? When it is said "from oriental population," it is not half answered. That population has destroyed its forests, and the very hells of filthiness and plague follow, spreading to the western world. Villages surrounded by forests in India, "are never visited by cholera, and troops are being withdrawn into forest stations in order to arrest the disease which it has been found is invited by removal of the forests." Ebermayer's observations are, that "so far no pathogenic microbes have ever been found in forest soil, hence this soil may be called hygienically pure." 
There is the Roman Campagna, once the glory of Etruscan industry and civilization. "Roman conquests, rapacity and cupidity destroyed the neighboring forests, and turned the fertile and beautiful plains into a pestilential morass where now only a few shepherds and swineherds drag out a miserable and precarious existence." The author of "The Cities and Cemeteries of Etruria" (2d Ed.1, p. 16) says that the unhealthy state of the reighborhood of the old Etruscan capital, the ancient Veii, spread to the whole campagna, "which in very early times was' studded with towns, but under the Roman domination became, what it ever since has remained -a desert, whose wide surface is rarely relieved by habitation."

So in Magna Grecia, in Lombardy, in Palestine, in the Valley of the Euphrates, in any and every part of the world where the forests have been literally wasted under the ignorance and greed of man, civilization has reverted into barbarism. The sequestered deserts have made humanity as desolate in body and character as are the howling winds among the ruins of ancient temples on those once forested and luxuriant plains.

We of the West, boasting of our liberty and national wealth, are provoking the very causes that destroyed oriental civilization. The health boards of the great cities of Europe and the United States give statistics, showing that vast multitudes of young children die every year for want of the pure, fresh air which trees and plants furnish fit for breathing. Dr. John H. Ranch, in his "Report on Public Parks," with special reference to the city of Chicago, "gives a series of facts, clearly proving that the infection and diffusion of malaria or noxious emanations are arrested by trees, whose structure and canopy of foliage act in a threefold capacityfirst, as a barrier to break the flow, second, as an absorbent of those emanations, and third, as eliminators of oxygen."

\section{GUARDIAY OF HEALTH.}

Springs and wells are more uniform in the woods than in the open, and purer and cooler. The forest is the guardian of the people's health. It wards off germ diseases. It fits the gases for blood vitalization. It generates nitrifying elements under its leafy and moist floor for the growth of our advanced plants. By its network of roots it sups up the stagnant water that would otherwise breed pestilences. Dangerous bacteria found in crowded cities and towns does not trouble wooded districts. Biederman's Ceneralblatt (Germanic) affirms that "the innumerable leaves and branches of a forest in a manner filter the air, and retain the micro-organisms which float in the lower grounds; besides woods cut the cold and dry winds so darigerous to the organs of respiration, and render the temperature more uniform." The air in treeless streets and badly ventilated rooms cannot produce healthful assimilation of blood and tissue, and germ diseases are there breeded. Wheat rust, potato blight and black rot are evidences of non-oxidized tissues. It is a well-known fact that rheumatic and catarrhal troubles are quite common in treeless regions. The free range of accessive hot and cold winds, depleting vital actian, favor the development of malicious compounds in the blood. In view of the correlation between un- 
oxydized blood and disease, both physical and mental, involving fearful costs, what public economy is more important for legislation than encouragement to tree planting and preservation?

\section{GOVERNMENT CONTROL OF THE FORESTS.}

\section{TESTIMONIALS.}

The American Forestry Association has taken the lead for government control of the forest cover of the country. Minnesota is perhaps as pronounced as any other state. The Forestry Association, now stronger than ever before, and the Horticultural Society, are a unit in this respect. Many of our presses favor it, and educational professors. It is believed that were it properly submitted to the people to vote upon, no doubt a large majority would answer in the affirmative.

Hon. S. M. Owen hits the nail as with a sledge hammer: "Governmental forest planting co-existent with governmental encouragement to forest destruction, is a bung-hole waste and a spigot-saving policy so idiotic that our pcsterity will be amply justified in derisively laughing at our folly; and it is a policy that cannot be changed too quickly."

Prof.Wm. R. Dobbyn, editor of "The Progressive Age," views the situation from a continental standpoint, maintaining what is evident fact, that national forestry is the foster parent of our civilization: "If we are to profit by the experience of those nations which have created bureaus of forestry, and through them have succeeded in reforesting their denuded territories, we will never cease agitating until Congress and the various states, each in their sovereign capacity, shall establish forestry departments of great energy. Nothing less than governmental forestry will save this continent from becoming a wind-swept, arid waste, and only intelligent agitation will ever create a public opinion out of which must be built those national and state bureaus of forestry. In the spirit of the patriot and in the spirit of the cosmopolitan, we therefore should agitate for the trees, the saviors of our civilization, the promise of our future."

J. S. Harris, one of our veterans in horticulture and forestry, and also, Col. Stevens, president of the Forestry Association and of the State Agricultural Society, place the great problem on the ground of human rights and unmonopolized usufruct of the forests. "There. is no man," says the former gentleman, "who has the right to eat up the bread that a 
future generation wants. He has no right to destroy the forests that favorably influence the climatic conditions of our time, and thus make it impossible for our successors to till the soil."

"To be successful," says C. L. Smith, former secretary of the Forestry Association, "forestry must be the protege of the state. The interest is too great, the stakes too high, the individual too selfish, the profits too remote, the climatic and sanitary effects too important, the benefits so universal, philanthropists so scarce, that the state should immediately take hold of the matter, and do something definite, practical and extensive."

Judge L. R. Moyer, superintendent of the horticultural station at Montevideo, Minn., says prompt measures should be taken to preserve the natural forests in the northern parts of the state. "No more timber school land should be sold. The state's title to all timbered land acquired at tax sales ought to be perfected, and the legislature ought to be prohibited by constitutional amendment from ever selling it. An intelligent forestry policy ought to be adopted, and measures taken to stop forest fires. As crops of timber mature, the stumpage or toe product ought to be sold under careful restrictions, so that the forest should be preserved, to the end that the state forests should always remain a source of permanent income to our noble commonwealth."

Hon. O. S. Whitmore, editor of "Hardwood," Chicago, Ill., a conservative exponent of the great lumber industry of the country, said in his able address at the forestry session of the Horticultural Society, January 11, 1893: "Methods of usufruct can and should be controlled by the state. Our hurried, feverish national growth has caused this point to be greatly overlooked. Should the state act upon it at once, the further destruction of forests by fire could be practically prevented. To accomplish this should be work for practical, rational forestry."

PROFITS OF THE NEW METHODS.

Until we can convince our lumber brothers that government control of the forests is more profitable than the present system, they will continue to "saw just the same." Mr. Whitmore presented the real merits of the situation: "This is a utilitarian age. Man works for the profit there is in it. The most practical part of rational forestry relating to existing forests is to convince the owner of a forest, be he lumberman or farmer, that it is for his interest to improve upon his present methods of treating it. When he shall be made to see plainly that it will pay him and his children to handle his timber as a periodical crop to be preserved with care, to be cultivated in a certain sense, to be protected from everything that might endanger it, as be would protect his corn field from weeds and insects, then will rational forestry have performed its'greatest mission."

TAXING TIMBER LANDS.

There is no question but that lumbermen are considering the question whether government control will better subserve their ends as viewed from the standpoint of profit. Already they raise objection on the ground "that the market value of cultivated trees, say twenty-five years old, does not 
cover the taxes imposed upon the lands where they grow; that the tax precludes forest preservation, and is really a premium offered and enforced by the state to eliminate the trees." This business consideration sways all their action, and the trees are going and will soon be gone, unless they are met by an argument more powerful than our talk.

Timber trees are the growth of centuries, and the planter or saver of trees would, of course, know he must die long before his pines or oaks reach a paying maturity. Such trees, like the nation itself, must from very necessity belong to the people as sacred to use as their constitution. Does not the long period of their development demonstrate that only by government control can their type be preserved and their just usufruct be protected?

Deploring the resultant calamities of denuding our woodlands, some of our leading lumbermen suggest non-taxation as an inducement to preserve them. To this the people will not consent for a single moment. Obviously exemption would induce swifter destruction, for the tax is then changed to the temptation of gain.

Again, lumbermen occupying our ground propose state bounties as inducements to preserve our native forests. It is as just to apply the bounty law to saving as to raising trees. The citizens of the woodlands, and they doubtless constitute a majority, have to pay their share of the bounty tax without a local and direct reimbursement; yet the representatives of the woodland constituency have voted for the bounty for the prairies with a manly generosity. A common sense justice would demand that the bounty be extended without respect of persons, comprising any and all available localities in the state, encouraging not only the planting but the saving of trees. Stipulate in the law that the woodland proprietor shall annually receive so much from the state, say $\$ 2.00$ per acre, when it is proved for a term of eight years that he has saved, or planted on denuded districts, so many pines, oaks, elms, etc., size mentioned and healthful condition, and then he would be interested in excluding fires and browsing cattle, and would be careful how he cuts. The premium plan with taxation enforced is practical so far as it goes; but it is obvious the state could not afford to pay bounty without limitation to acreage. Hence it would fall to meet the demand for forest accumulation.

\section{THE BILTMORE FOREST SYSTEM.}

The first practical application of scientific forest management in the United States has been initiated in North Carolina, known as the Biltmore Estate, owned by George W. Vanderbilt, and superintended by Gifford Pinchot. It covers 7,282 acres. An illustrated exhibit of it occupied a prominent position at the Columbian exposition in the Forestry Building. Mr. Pinchot is a well-posted forester and understands what he is about. His report of the first year's work, commenced May 1, 1892, on this estate, is very creditable. It gives an elaborate description of the locality on the 
French Broad River in the western part of that state, its configuration, its geological deposits, its meteorological peculiarities, its natural species of trees, its injured forest condition arising from haphazard cutting of the better trees, frequent fires and the browsing of cattle. Mr. Pinchot says that "at the time when the forest management was begun on the estate, the condition of a large part of the forest was deplo tble in the extreme."

FIRST YEAR'S PROFIT.

By cutting such trees as was necessary to begin the improvement, amid the widespread chaos, and selling the same for lumber, cord-wood and railroad ties, there was realized a balance, net, of $\$ 392.40$, first year. It is presumptive that with judicious and economic management, the profits will augment from year to year, and instead of raiding the forest for money considerations, it is fitting it to be a profit investment for all the years to come.

\section{ARBORETUM DRIVE.}

A nursery has been established on the estate, already containing more kinds of trees and shrubs than there are in the botanical gardens at Kew, near London, and the number is being steadily increased. It is the intention to plant these along the line of a road to be called the "Arboretum Drive." This road, about five miles in length, will run through some of the most beautiful portions of the estate, and will be lined for a hundred feet on either side by the plants of the collections, making this arboretum the finest in existence.

\section{IMPROVEMENT CUTTINGS.}

The reader will note with what prudence Mr. Pinchot proceeds in the start. He found the "old spreading trees were seriously injuring the young growth below them, and it was impossible to found a system of management on the lives of the older specimens, which, in very many cases, were already perishing. It became necessary, therefore, to institute a series of improvement cuttings which should remove these older trees, and prepare the way for a working plan under the Regular High Forest System, the characteristic of which is that the trees of the same age are grouped together, so that there are (theoretically) as many separate groups as there are years in the age of the oldest trees."

\section{LIMITATIONS OF CUT.}

He found two limitations imposed themselves at once. "No older trees could be cut where the young crop was very far from being dense enough to protect the soil, and no cuttings could be made which would cost more than the value of the product. The term of six years was tentatively set for carrying out these cuttings and the inaugurating of the working plan. It was almost impossible to set a shorter period, for the reason that in many cases all the old trees could not be cut at once, on account of damage to the future crop; and for the same reason not less than five years must intervene between the first and second cuttings on the same ground." 


\section{EFFECT OF THE IMPROVEMENT CUTTINGS.}

"So far as can be judged at this early date, the improvement cuttings seem to have accomplished what was expected of them. The appearance of the forest where they have passed is much improved, and the young trees which have been set free are doing well. But, although it is too early to pronounce definitely upon all of their effects, two facts seem to have been established. These are, that large trees surrounded by a dense growth of smaller ones may be felled and removed with comparatively very unimportant injury to the young crop, and that the additional cost of the necessary care, beyond that of ordinary destructive lumbering, is so small as to be out of all proportion to the result. If this latter fact should be established later on in other parts of the United States, as there seems little reason to doubt that it will be, its importance to the future success of forestry will be very great. Its value in practice is enormous."

\section{OUTLINE OF THE WORLING PLAN.}

Unoer the Biltmore System the working plan is made elastic. Its general objects are three in number: 1. For profitable production, giving the forest direct utility. 2. A nearly constant annual yield, which gives a steady cccupation to a trained force under a permanent organization, and making regular operations possible. 3. Improvement in the present condition of the forest.

\section{REGULAR HIGH FOPEST SYSTEM.}

"These general objects are to be attained by means of two systems of management. On the east side of the French Broad the Regular High Forest System will be adopted, and the Selection System on the west side. In each case the rotation, or the length of time in which a second crop becomes ripe on the same ground after the removal of the first, was fixed at 150 years. In a theoretically perfect forest, under the Regular High Forest System, there would be as many sub-divisions as there were years in the rotation. The trees of each sub-division would be of equal age and would differ from those of the next sub-division by one year. In the present case, for instance, the oldest sub-division, bearing trees 150 years of age, would be ready for the ax; and the cutting, after passing over it, and then over all the others in succession, would reach it again at the end of 150 years."

\section{SELECTION SYSTEM.}

"The Selection Forest in its perfect state has trees of all ages mixed together everywhere instead of being separated into groups of uniform age. The annual yield is taken each year from all parts of the forest. But under such a method transportation would manifestly be too costly for American conditions. Consequently, the Localized Selection System was adopted in its place. Under it the annual yield comes from a restricted portion during several years; then from another portion during a like period, and so on until the cutting has passed over the whole forest. In the present case the 
yield will come from one-fifth of the area during each period of five years. Consequently the cutting will return over the same land once in twentyfive years."

\section{OUR SUPERIOR PRIVILEGE.}

The object of making the Biltmore case so conspicuous in this report is to show that order can be instituted in the forests of Minnesota, where the conditions are similar. The assurances of success are at least 50 per cent ahead of the venture in North Carolina. Our lumber territory, our transportation by water and rail, our mill facilities, our lumber and fuel markets, are superior in every particular. We have at least a hundred-fold more raw material to utilize than North Carolina or any other southern forested state.

\section{ACCEPT THE SITUATION.}

What hinders Minnesota, then, from undertaking to commence a forest improvement system, not exactly after the pattern of Biltmore, but as our privilege warrants for business enterprise? We have no time to brood over the ruined condition of our forests, nor to berate any one for producing those conditions. Let us accept the situation and see if we cannot make it pay to bring order out of chaos.

\section{WILI, LUMBERMEN COÖPERATE?}

We cannot reasonably anticipate that lumbermen will pause in their work to consider experimental methods, or turn back to reconstruct where forest injury has been wrought. Not yet. We must be content with the fact that really they are friends of practical forestry, and do countenance the object we have in view, but are not ready to adopt it.

\section{AN AVAILABLE POLICY.}

Prof. S. B. Green suggests the feasibility of utilizing a large tract, a whole township perhaps, of the university lands as a branch experimental station in the northern part of the state, located among the lakes there and protected by the native trees. The chances certainly are excellent. Under proper management it would more than pay for itself, and be of immeasurable benefit to the state. This would be a good beginning.

\section{INIMICAL TO A REPUBLIC.}

But individual or corporate ownership of great landed estates, whether forested or not, are inimical to a republic. As in the old countries, it excludes the common people from the shade and health-giving influences of the thickets. It becomes the hunting grounds of the landed aristocracy. It fortifies monopoly. Besides such ownership does not secure a permanent forestry. Such estates are liable to be sold and cleared off, and the climatic benefits neutralized. Generally private ownership of forests is destructive to forests.

As a rule lumbermen let taxes go by default, after they have cut off the timber. This turns such lands over to the state, but the state does no better, except to sell here and there a quarter section of denuded land to 
some poor man who is willing to settle on it. As the state makes no provision to forestall annual fires, the ruin continues until the very fertility of the soil is entirely eaten out. If this is a practical policy, then is desertmaking präctical.

\section{TAX TITLES ON WOODLANDS.}

Where the locality is promising, men buy the taxes on special woodlands, denuded of market timber, and hold them for speculation in the future-a reprehensible law and business. Our legislature has the right and power to foreclose such titles, and to consecrate such lands to forestry in the form of parks and reserves. Fires excluded and cuttings economized, even without special culture for the present, they would soon begin to recover a wooded condition, improving the soil, augmenting in value and blessing the people with increase of atmospheric moisture and eventual water-flow over their now desolate regions. The Forestry Association respectfully submits that such a legislative policy is the best possible disposal of such lands.

\section{PERCENTAGE OF GOVERNMENTAL OWNERSHIP.}

In Germany two-thirds of the forest area is maintained by the government. In Austria 13 per cent of the forest area is in the hands of the government. Switzerland has only 4 per cent of its forest under complete governmental control, but governmental control is exercised over 66 per cent of her forest area. Italy owns but 1.6 per cent of her forest area. A law was enacted in Italy in 1888 requiring reforestation of all desert mountain lands. In France the government prevents the cutting of timber even on private lands when that cutting is detrimental to the public welfare. Ten por cent of the French forests are held by the government. Spain owns $4 \frac{1}{2}$ per cent of her forests, but controls eighty per cent of her forest area. Fifteen to 20 per cent of the Scandinavian forests are owned by the government. Russia owns two-thirds of her forest area. England has just begun the work of planting trees in waste places. India's forest revenue amounts to several million dollars annually, but Germany leads the world in forest management.

\section{GOVERNMENTAL INCOME.}

Prussia, from her 6,000,000 acres of state forest, receives an annual net income of $\$ 7,000,000$. Saxony, from her $4,000,000$ of forest lands receives an annual net income of $\$ 1,125,000$. Bavaria, from her $3,000,000$ acres receives annually a net profit of $\$ 4,500,000$.

\section{THE STATE'S PREROGATIVE.}

The figures prove that where forests are properly managed, profit ensues in due time. Why should not the state, then, rise to the emergency? It regulates pharmacy, dental art, telegraphy, navigation, mining and the like, why not assume equal responsibility over the forests, seeing their preservation concerns all these other interests? Every year's delay lessens the hold of the people upon the forests and heightens the impending peril to our climatic and agricultural dependencies. 
But the state, years ago, committed itself to government forestry by virtue of the tree bounty law under whose beneficent workings more than a hundred thousand prairie acres have been substantially planted with trees, and there is no room for turning back. Why should not the state hold supervisory control over the trees it has liberally paid for? This rule being legitimate, why not extend it in application to our natural forests, more especially such as are yet owned by the state? And why not sanction, and coöperate with, the federal government in a like control over unentered lands that are more profitable for tree-raising than agriculture, and absolutely necessary to water conservation? Such control would lease the cutting on government land, enforce economy, exclude fires, cultivate and save the "fittest," making the great labor-providing enterprise pay better than the present method, and improve all dependent industries.

In some parts of Europe, we are informed, where forestry is reduced to a profitably practical system, the government awards the proprietor of a forest in installments, for a series of years, to preserve it intact, he using some of the coppice and rotting clown wood, if any, for his personal needs. The private forests are thus placed under governmental supervision, allowing no destruction of any of the valuable timber; and when said timber is matured, the government cuts and markets enough of it to get its pay back. Thus the proprietor is encouraged to plant and conserve his forest by getting a premium in advance, and the government subsequently makes itself whole, and the people have the climatic benefit of it. Somesuch way is this seems to be our necessity. It certain'y removes the objection of jaying out money with a money equivalent returned.

\section{THE RESERVE SYSTEM OUTLINED.}

As a means to a general governmental control of the available forest zover of the state, a movement was put on foot to secure a forest reserve. Wyman Elliot thus defines the location of it: "Where is there a more appropriate place for an extensive experiment of forest growing under government control, than in the northern part of Minnesota, and one where there is so great need of preserving the ameliorating effects of climatic conditions?"

Basing action on the congressional law of March 3,1891, this movement, in the early part of that year, was projected by the State Forestry Association to locate said forest reserve on the public lands at the head waters of the Mississippi, Red, iSt. Louis and St. Croix Rivers. Our legislature, then in session, passed a joint resolution to this effect, but limited its area to so small a compass as to render it abortive of the end sought. A petition, signed by leading citizens, asking for six millions of acres for a national reserve, was subsequently sent, with showers of others from other states, to President Harrison. He proclaimed six reservations in the regions of the Rocky Mountains.

\section{INCOMPETENCY OF THE ACT.}

Unfortunately the law opened up to almost. unrestricted use of all timber lands not so reserved. While it implied an unlooked for license to deforest adjacent territory, it virtually denied encouragement to agricul- 
ture, railroading, mining, etc., within the reservations. Summing up these defects, Land Commissioner Carter recommended that "provision should be made for the immediate reservation of all public lands bearing forests or timber, except for entry and mining lands."

Tre defects in the law and the crudeness of our original petition were followed by strong remonstrances against the Minnesota reserve, and it was left out of the list of proclamations, with several others like situated.

NEW BASE OF OPERATIONS.

Gaining ground by experience, the Minnesota foresters joined with those of other states, demanding a law which, as stated by Mr. Carter, "shall make adequate provision in respect to both forest reservation and the cutting and removal of timber to supply the public necessities." Finding our lumbermen and other business citizens endorsed this suggestion of the land commissioner, our State Forestry Association has since issued the following petition, which is here again laid before the candid consideration of our people in confident trust that they will not only endorse it, but heartily work to secure something of the kind before the lands there are so placed as not to be available for a reserve. A like petition has been endorsed by the State Horticultural Society:

PETITION FOR A FOREST RESERVE.

\section{To the President of the United States:}

The undersigned citizens of Minnesota set forth that the annual fires on the woodlands of the public domain have destroyed much valuable timber and largely injured the forest conditions necessary to economize our waters; that the stealing of timber has been immense; that the methods of cutting have been wasteful and ruinous to timber preservation and culture. We therefore respectfully urge the passage of a bill which shall ask for a practical system of forestry, managed by proper police forces to guard against fires and trespass and develop forest growth. In accord therewith, w€ respectfully urge that a reserve in one body, or in separate sections, be located on the public domain at the sources of the Mississippi, Red, St. Louis and St. Croix Rivers, or other points, carved out of non-agricultural lands, aggregating not less than 2,000,000 acres, and so regulated as not tc restrict the rights of bona fide sottlers, nor the rights of lumbering, mining and railroading, but rather to promote those industries without detriment to forest preservation. 


\section{THE FOREST RESERVATIONS BILL NOW}

\section{BEFORE CONGRESS.}

There is now pending in congress a bill (H. R. 119) to protect forest reservations in the United States, but just what it provides may not be generally known.

The bill was introduced September 6, 1s93, by Hon. Thomas C. McRea, chairman of the committee on public lands in the House of Representatives. The measure is entitled, "A Bill to Protect Public Forest Reservations," and is divided into eight brief sections, as follows:

" Be it enacted by the Senate and House of Representatives of the Cnited States of America in Congress assembled, That all public lands heretofore set apart and reseryed by the President of the United States, under the prorisions of the act, approved $\mathrm{March}$ third, eighteen hundred and ninetyone, or that may hereafter be set aside and reserved as public forest reservations, shall be, as far as practicable, controlled and administered in accordance with the provisions of this act.

SEc. 2. That no public forest reservation shall be established except to improve and protect the forest within the reservation, or for the purpose of securing favorable conditions of waterflow and continuous supply of timber for the people.

SEC. 3. That the Secretary of the Interior shall make provisions for the protection against fire and depredations of the public forest reservations set aside, or that may be set aside, under the said act of March third, eighteen hundred and ninety-one, and he may make such rules and regulations and establish such service as will insure the objects of such reservation, namely, to regulate their occupancy, to utilize the timber of commercial value, and to preserve the forest cove from destruction: Provided, that no timber of commercial value shall be sold except to the highest bidder on sealed proposals after due appraisement, as hereinafter provided, at not less than the appraised value thereof.

SEc. 4. That before any sale of timber of commercial value on any forest reservation shall be made, notice thereof shall be given for at least thirty days in a newspaper of general eirculation printed and published at the capital of the state or territory, and shall also be published, when practicable, in a newspaper printed and published in the county and counties in which such reservation is situated, describing by numbers the tracts of land on which the same is situated and the location thereof, and designating the land office of the district in which the land is situated as the place where such sealed proposals will be received, and stating the time within which such sealed proposals will be received. All such saies will be for cash, payable at the time of sale at the land office of the district in which the land is situated, and the proceeds shall be accounted for by the receiver of such land office in a separate account, and shall be covered into the treasury as a special fund to be expended in the care and management of such reservations in such manner as Congress may provide. 
SEC. 5. That the Secretary of War is hereby authorized to make such detail of troops for the purpose of protecting said reservations as the Secretary of the Interior may require.

SEC. 6. That any public lands embraced within the limits of the forest reserve which, after due examination, shall be found better adapted to agricultural than forest uses, may be restored to the public domain upon the recommendation of the Secretary of the Interior, with the approval of the President, after sixty days' public notice in two newspapers of general circulation in the state or territory where the reservation is situated.

SEC. 7. That any timber on the public lands, not within a forest reservation, may be sold by order of the Secretary of the Interior in the same manner as is heretofore provided in this act: Provided, That it shall be first shown that such cutting will not be injurious to the public interests: And provided further, That no timber on the public lands shall be disposed of except in accordance with the provisions of this act.

SEC. 8. That all acts and parts of acts inconsistent with the provisions of this act are hereby repealed.

It might be added that Secretary of the Interior, Hon. Hoke Smith, approves of the bill, and Hon. W. M. Stone, Commissioner of Public Lands, has recommended its passage. The original bill did not contain all the above, but several amendments have been inserted, which make it satisfactory to the officials named. Let the reader apply above bill to the needs of Minnesota. Shall we act or shall we be supine respecting a forest reserve?

\section{FORESTAL IRRIGATION IN MINNESOTA.}

There is such a dearth of water during the dry seasons these years, and when our agricultural and tree crops most need it, resulting in poor harvests, that the matter of irrigation must be considered. Necessity drives us to provide some way by which the surplus water in the spring, usually rushing in destructive floods and reacting into severe drouths, can be conserved and economically distributed. The state legislature has not estimated geodetic surveys as of practical importance enough to have it done on the scale which our necessities demand. It is certain that were all the water falling from the clouds and gushing from the springs and running to waste, harbored in ample reservoirs at or near our numerous watersheds, and thence made to flow over our lower lands, under proper management, the uncertainty and cankering anxiety about our crops and trees would be ended, and their abundance increased almost beyond measure. Where the reservoirs should be established, will have to be determined by competent surveyors.

\section{RESERVOIRS IN WESTERN MINNESOTA.}

According to the annual report of Maj. W. A. Jones, of St. Paul, engineer in charge of the government works on the rivers of the Northwest, a great 
reservoir system on the Red and Red Lake rivers is unquestionably feasible. "It is well known," says the Daily Herald, of Grand Forks, N. D., "that the northern portion of the state of Minnesota, and especially the portion directly east of the Red River Valley, is composed, to a large extent. of a vast number of small lakes, besides Red Lake, which is of considerable area. These lakes comprise a number of great water basins forming the head waters of the Mississippi and Red Rivers. The waters east of the 'divide' going to the Mississippi and thence to the Gulf of Mexico, while the waters to the west of the same 'divide' eventually find an outlet through the Red River to Hudson's Bay. The topography of the territory comprising the head waters of the Red River is shown by the investigations of Major Jones to be admirably adapted to permit the formation of a large storage reservoir, which will not only allow the vast quantities of water which occasions the spring floods to be held in check, but admit of the same water being utilized in increasing the volume of water during the dry seasons. Red Lake can be utilized in the same manner as a storage reservoir by the construction of dams at the outlet of the lake, which will raise the water two feet above its normal height when needed, and also by means of dredging, permit the water in the lake to be lowered two feet when needed to keep up the volume of water in the river. Major Jones is confident that by the judicious arrangement of dams and the reservoir system proposed, not only will the inconveniences from floods and low water be largely done away with, but the Red River will be made ravigable throughout the season from spring to freeze-up in the fall, and the Red Lake River will be made navigable the entire distance to Red Lake."

\section{WHERE CONSTRUCTED.}

In concluding his report, Major Jones says:

"An increase of 1,000 cubic feet per second to a low water discharge of 350 seconds would render further operations under our project for improvement unnecessary, and make an exceedingly fine line of water trans. portation.

"In order to furnish this increase to the volume of discharge, the waters from the water-shed of Red Lake could be assembled in one reservoir, and those from the Otter Tail might be gathered in Lake Traverse as a reservoir by means of a dam at Breckenridge. This would seem to be a feasible and economical method of solving the question of the Red River of the North permanently, and hence I consider the matter worthy of the favorable attention of the government. In order that it may be fully investigated and the estimates called for submitted, a survey will be necessary, for which purpose, I estimate, the sum of $\$ 6,000$ will be necessary."

\section{AREA OF THE NEW RESERVOIRS.}

NFajor Jones estimates the area of the Red Lake reservoir at 1,930 square miles with $9,000,000$ cubic feet of water for each square mile, or 17,370 ,000,000 cubic feet of water output in one year. The area of the Lake Traverse reservoir is estimated at 2,450 square miles, or $31,050,000,000$ 
cubic feet of water. He further estimates that this would add an average of 2,000 cubic feet of volume to the Red River at Grand Forks in low water, giving a navigable draft of $5 \frac{1}{3}$ feet below this city to the boundary line.

\section{THE WEIGHTIER QUESTION.}

The object these gentlemen have in view is the navigation of the waters mentioned. But a weightier question arises-whether the reservoir and canal system proposed can also be applied to irrigation; probably not, if navigation only is to be promoted, for there might not be water enough to go round. But the interests of agriculture, which includes forestry as ts prime factor, takes the precedence of navigation. Were the reservoir system extended as Major Jones suggests, and used mainly to head a vast irrigation system, under right forestation of the spring lands, it would pay a hundred fold more to the people than navigation at its most prosperous tides of commerce. There is no call for such navigation unless our crops warrant it.

\section{WHAT CAN BE DONE PRACTICALLY.}

As demonstrated in this report, without economic forest management econowic water management is impossible. If the state would have water supply, the wild and waste territory at the sources of our great water systems must be densely forested for a perpetual cover. Practical management of water implies arrangement for water drainage. Then irrigation becomes as beneficially applicable to well-watered as to dry and arid regions. In all countries where scientific irrigation is operative, it is found to be far more satisfactory than irregular rainfall, even if ample, whose mechanical action in falling compacts the ground and impedes percolation. Not so with irrigational water; it can be applied when needed, on the surface in gentle flow, or among the roots by underground piping, by which also provision is made for safe escape of surplus.

Up to this date the chain of reservoirs is circumscribed to the waters of the Mississippi. The national government can be influenced to extend them to the headlands of the St. Croix and St. Louis rivers and lakes in those regions, drawing such waters eastward and southward, and extend them also so as to more closely interlink and economize all the lake waters of the park region, and, as proposed by Major Jones, to locate a great reservoir in Red Lake, with which to supply the Red River Valley. Indeed, the reservoir system could be practically applied and utilized over the southern portion of the state with equal facility.

Consider for a moment what can be done in perhaps the most difficult part of Minnesota. Suppose a suitable dam be placed at the mouth of Otter Tail River, as suggested by Major Jones, to supply water for the southern balance of the Red River Valley, and thence farther south wherever feasible; for this object another dam be placed at the head of Traverse Lake, another at the foot of Big Stone Lake, and so down at all the principal falls of the Minnesota River, and next water-wheels at all these dams, with other proper machinery, for lifting and distributing the 
water, would it not be a feasible conquest over the drouth? Such an irrigation system, so absolutely needed, is no more gigantic than what is already operative in the Rocky Mountain region, or anciently in the valley of the Euphrates. Nor would the cost be any greater. The policy should be to irrigate experimentally and avoid reaction. We can congratulate ourselves on the fact that we have innumerable spring brooks scattered over the state on the prairie as well as woodland, which, if utilized and secured in spacious basins, would afford suitable water for the bottom lands through which they flow. We have not yet tested our artesian supply, as in the Dakotas, where it proves so successful, even if the water has to be forced up to elevated tanks. It requires but slight descent of land for irrigational purposes.

\section{AMOUNT OF WATER NEEDED.}

The amount of water required is far less than is generally supposed. The usual standard is a miner's inch, and one-half to three-fourths of an inch per acre will suffice when economically applied. The actual size of an irrigational ditch, earrying from fifty to one hundred inches of water, is from three to four feet wide and twelve to eighteen inches in depth, and this requires for available flow but one-eighth to one-quarter of an inch per rod.

INCREASE OF CROPS.

Hon. S. M. Emery, formeriy of Minnesota, now director of Montana Experiment Station. Bozeman, Mont., states in his address on "Irrigation for Minnesota," delivered before the annual meeting of the State Horticultural Society, 1894, that after the ditches are once constructed the cost per acre for applying the water will not exceed $\$ 1$ per annum, and that lands, as a rule, need irrigating but once, twice or thrice in a season, depending on soll conditions and locations; "that each acre upon which you can conduct water means four acres, as its production is increased from two to threefold from irrigation; and, if this be true, the acre that by the same labor doubles or triples its yield, is as valuable as four times the land, considering the material reduction in labor involved in the cultivation of four acres as compared to that of one."

\section{INITIAL STEP BY THE IRRIGATION CONGRESS.}

Here is a subjoined extract from an address to the people of the United States, prepared by the National Irrigation Congress at its recent session at Los Angeles, Cal., alike applicable to Minnesota:

"We favor the limitation of the amount of land that may be taken up by settlers under systems of irrigation to iorty acres, and predict that in the future it will be found desirable to reduce the amount still further, and we favor the restriction of the privilege of taking up public lands to citizens of the United States. This has become necessary with increase of population, and is also desirable as rendering more difficult the acquirement of lands for speculative purposes. We call attention to the growing importance of the storage problem, and demand rigid national and stat" supervision of dams and other works, in order to protect life and property. 
"We especially urge the importance of an enlightened policy for the care and preservation of the forests against wanton destruction by fire and otherwise. We indorse the policy of forest and storage reservations covering the mountain watersheds of the West. The importance of due care and protection of these watersheds to maintain the perennial flow of springs and streams, and to prevent floods and torrents, demands the establishment of a wise forestry system. Pending the establishment of such an organization, we favor the use of detachments of the United States army to protect all the western mountain water sheds from injuries detrimental to the highest use of the valley lands."

\section{TREE BOUNTIES.}

The tree bouhty law dates back to 1873. Since modified, it now specifies the number of trees required per acre, limiting the bounty to $\$ 20,000$ per year at $\$ 2.50$ per acre. According to the records, about 74,000 acres of forest trees, exclusively under the operations of the law since its enactment, have been successfully raised on the prairie regions of the state. The aggregate for all the planting in the state during the last ten years tallies all of 100,000 acres. During the last forty years of tree planting in Minnesota, the number of trees, it is safe to say, is well nigh the billions, and yet the beneficent work is but begun.

The following letter from the state auditor gives a summary of the work done during the fiscal year, ending July 31,1894 :

\section{HoN. J. O. Barrett, Brown Valley,}

St. PAUl, August 16, 1894.

Deur Sir:-Replying to yours of the 16th inst., will say, that the total amount paid for tree planting for the year ending July 31, 1894, has been $\$ 16,988.24$. The bounty has been paid to 2,123 different persons, and the area planted is 6,795 acres, each acre containing on an average $6 \pi 6$ trees, which makes a total of $4,593,420$ trees.

I also enclose the financial statement of the appropriation for forestry association.

Respectfully yours,

\section{A. Biermann, State Auditor.}

To be entitled to bounty, applicants must show that trees were originally planted not more than eight feet apart each way, and were kept in a thrifty, growing condition, and were maintained at a distance of not more than 
eight feet apart each way by replanting each year all that may have died during the year. Application should be make July 1 to 15 to state auditor for blanks. The assessor records your answers to the questions on the blank. In all cases two freeholders, residents of your town, must attest your statement, together with the assessor's acknowledgment of its validity. It must then go to the county auditor for attestation, and when it reaches the state auditor, and all is right, you get your bounty. But woe to him who swears fraudulently. "Better for him that a millstone were hanged about his neck, and he were cast into the sea."

There is no analogy between a crop of wheat or corn and a forest grove. Trees are not annuals; they belong with the centuries for successive generations. The man who raises them cannot monopolize their benefits if he tries. In a climatic and sanitary sense they are not his alone, though on his own farm. As wind-breaks they protect whole neighborhoods, imparting salubrity to all the air we breathe. They are educators of patriotic and æsthetic character. Along these lines of use they intrinsically are above all price. Surely the state can afford to improve the general prosperity, healthfulness and beauty of its vast domain.

\section{DISCURSIVE.}

\section{HOW TO SAVE THE TREES.}

The indiscriminate destruction of forests is a waste of material in wood and water, an injury to the animals and the soil, and an insult to the æsthetic taste of man. It should be prevented by law and by public opinion. There are abundant reasons for practicing what is called scientific, 1. e., common sense forestry in the interests of the lumber trade, agriculture, the fisheries, and the preservation of water power for mills, and of water supply for cities. The value of the crop that can be gathered with little labor from a forest area on the average of a century, compares favorably with the crop that can be raised with great labor after the forest is cleared away and the rain is allowed to leach the soil until it becomes unproductive gravel. *** The influence of the forest on the general welfare of the community is so decidedly beneficial that it behooves Minnesota to promptly take steps to preserve the generous woodland that she has inherited from the past centuries. Certain areas must be permanently cleared for agricultural or other purposes, but all that is not thus treated should be kept covered with groves or forests. 


\section{ROTATION OF TREE CROPS.}

The principle of rotation of crops, as recognized for ordinary grains and roots, should be made to include the forests, and it should be a recognized principle that after fifty or one hundred years of agriculture there should come the same interval of forest culture. Every acre that is cut over simply for lumber or other purely forest crops, should be immediately replanted to at least the same extent as that to which it has been deforested. State foresters should be commissioned to enforce rational laws as to cutting and clearing.

\section{COMMUNAL INTEREST.}

These restrictions on personal freedom are based on the principle that the whole community is interested in the preservation of its forests; they affect the water supply, the water power, the birds and animals, the purity and even the temperature of the air we breathe. A lumber state has the same right to protect its forest that a commercial community has to protect its harbor and channel, or a mining community to demand the ventilation of its mines, or an agricultural community to protect its system of irrigation ditches and reservoirs. To cut the wrong trees, leaving half of them rotting on the ground; to destroy a forest without at once starting young trees to replace it; to leave exposed hillsides that will send destructive floods into the valleys below; to dry up the ponds, lakes and springs, all this is a loss to the community and an improvident waste, as serious as the careless burning of the forests. The general good of the commonwealth demands conservative forestry, and it is the duty of the people to enact and support laws for such self-defense.-Prof. Cleveland Abbe, Weather Bureau, Washington, D. C.

\section{SUCCESSION OF FOREST GROWTH.}

Lumbermen say: "When the pines are gone, they are gone forever." But what are the facts? From time immemorial such trees have grown in various parts of the old and new world in the same places where nature has been allowed to have her own way. The pines of Maine have been cut over and over again on the same wild grounds. The ancient oaks of Britain have replanted themselves times without number on the very spots where the Druids wershiped. The redwoods of California and elsewhere yet live among their giant ancestors that date back even before the beginning of the Cbristian era Despite human rapacity, the great cedars of Lebanon, whose sires were cut by King Solonion for his temple, have repeated themselves on those shaggy heights-a few yet lingering under religious protection. The olive trees of Palestine, and the fig trees, and the willows on the lower banks of the Jordan, under whose shade the nomadic Israelites pitched their tents, have again and again during all the centuries since. 
replanted themselves there, rebutting the lie that they do not succeed each other. If these instances are exceptions to the rule, they count for the rule when conditions warrant it.

\section{RETROGRESSIVE FORESTRY.}

If we rob the supports of the pines or any other class of trees, of course they will die out and another species of less value may take the ground and hold it. The reason why we observe so many tree rotations is because we interfere and produce the conditions that necessitate them. "When the pine forest is burned over," says Robert Douglas, "both trees and seeds have been destroyed, and as the burned trees cannot sprout from the stump like oaks and many other trees, the land is left in a condition for the germination of tree seeds, but there are no seeds to germinate. It is an open field for pioneers to enter, and the seeds which arrive there first have the right of possession." The cotton-winged seeds of the aspens and other poplars generally get ahead, taking root on high and dry soil, where some other seeds would die. The burnt land is their paradise, and their paradise is the forest retrogression which our lumbering methods have paved the way for.

\section{CAUSE OF NON-SUCCESSION.}

Conifer and other seeds may sprout under their parent trees, but their young shoots speedily pale and die, if the shade is too dense. The same result occurs, though in reverse order, where the trees are all cleared off. If they sprout, the sun's excessive heat soon kills them. If a fire burn up the leaf mulch and the root network in the soil, of course the seeds are destroyed, and we have no succession of forest growth there, simply because "we cannot make something out of nothing." Observing there no reappearance of the old species, men aver "The pines once gone are gone forever," and they ring the changes on this "lumber adage," to convince us that it is useless to try to save our pines!

\section{DOES NOT "RUY OUT."}

Some common sense needs to be drilled into some people's understanding. By the decay of fallen leaves and limbs, mosses and other minor vegetations, aided by water thus conserved, forest trees manufacture their own nutrition and support. Hence forest soil that is not raided by axe or fire does not "run out" like a farm soil planted with the same kind of seeds from year to year. It is plain that successive tree crops will continue to grow and do well on their own native heath under a practical system of forestry whereby the forest conditions are improved by cutting for the market. 


\title{
FACTS TO CONSIDER.
}

\author{
LESSONS OF WARNING.
}

Less than seventy years ago, Bucharia was "one delicious garden, on every side, villages, rich cornfields, fruitful orchards; country houses, gardens, meadows interspersed by rivulets, reservoirs, canals-a lively picture of industry and happiness." About forty years ago, a mania of clearing the forests seized upon the inhabitants; they cut down the trees, and what was left was ravaged by fire during a civil war. Result: the waters dried up, the sands of the desert swept over that fair land, and next came desolation and solitude.

A like fatality arising from deforestation fell upon parts of India, Turkey, - Greece, Egypt, Italy, Spain, the once luxuriant valley of the Euphrates, Palestine, and so all around the world where man has presumed to unbalance the meteorological forces of nature.

The present arid hills and worn-out fields in New England, in Pennsylvania and other Middle States, and in the sunny South, report the same sad story, that waste and desert follow the destruction of the forests in those once favored localities.

\section{WASTED RESOURCES.}

We have wasted and are still wasting our resources in fish and game, in forests and water sources, in the fertility of the soil and in other storehouses of the nation's natural wealth, as if responsibility to the future for our action as trustees of this magnificent inheritance had for us no existence- $-J$. B. Harrison.

\section{ERA OF HUMAN IMPROVIDENCE.}

The earth is fast becoming an unfit home for its noblest inhabitant, and another era of equal human crime and human improvidence, and of like duration with that through which traces of that crime and that improvidence extend, would reduce it to such a condition of impoverished productiveness, of shattered surface, of climatic excess, as to threaten the depravation, barbarism, and, perhaps, even the extinction of the species.-Geo. P. March.

"So profound is our ignorance and so high our presumption, that we marvel when we hear of the extinction of an organic being; and as we do not see the cause, we invoke cataclysms to desolate the world, or invent laws on the duration of the forms of life."-Charles Darwin.

\section{APPALLING MAGNITUDE.}

The appalling magnitude of the destruction of timber in the Northwest will, perhaps, be made plainer to you by giving the lumber statistics of the cut of white pine in the Northwest for 1892, saying nothing of the enormous hardwood cut. The number of feet, is as follows: 
On Mississippi, above Minneapolis................ 109,863,378

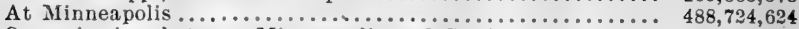

On main river between Minneapolis and St. Louis......... $931,806,305$

On - St. Croix river............................ 175,891,427

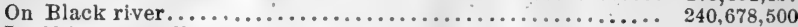

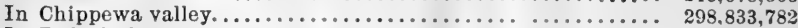

In Duluth district.............................. $349,394,000$

St. Paul \& Duluth railway..................... 75,955,000

Ashland district.................................... $373,229,877$

St. Paul \& Omaha railway........................ 286,311,383

Wisconsin Central railway...................... $301,806,875$

In Wisconsin valley.......................... 456,153,872

Sault Ste. Marie railway...................... 293,565,541

In Red River valley (estimated)................... 100,000,000

Taken to Canada (N. W.)......................... 150,000,000

Total ........................

\section{CRIMINAL IMPROVIDENCE.}

It is the timber thief, making haste to strip the public domain of what he can lay his hands on, lest another timber thief get ahead of him, and in doing this, destroying sometimes far more than he steals. It is the tourist, the hunter, the mining prospector who, lighting his camp-fire in the woods to boil water for his coffee, or to fry his bacon, and leaving that fire unextinguished when he proceeds, sets the woods in flames and delivers countless square miles of forest to destruction. It is all these, but it is something more, and, let us confess it, something worse. It is a public opinion looking with indifference on this wanton, barbarous, disgraceful vandalism. It is a spendthrift people recklessly wasting its heritage. It is a government careless of the future and unmindful of a pressing duty.

No respectable university or agricultural college should be without a department in which forestry as a science is taught; and most of us will no doubt see the day when the importance of that science will be recognized by every thinking American. Let us hope that this appreciation will come in time. I regret, we cannot forcibly enough impress upon the American people the necessity of speedy measures looking to the preservation of our mountain forests, which, when once destroyed, cannot be renewed. Unless this be done in time, our children will curse the almost criminal improvidence of their ancestors, but if it is done in time, those who are instrumental in doing it will deserve and will have the blessings of future generations.

To bring up the public opinion of this country to the point where it will command such measures, a vigorous and unceasing agitation is required. I do not underestimate the difficulties it ${ }^{\circ}$ will have to overcome. It is the shortsighted greed which acts upon the rule to grab all that can be got at the moment, and "let the devil take the hindmost," not stopping to consider that he who does so may be among the hindmost himself, and that in this case his children certainly will be. It is that spirit of levity, so prevalent among our people, which teaches to eat and drink and be merry to-day, unmindful of the reckoning that will come to-morrow. It is the cowardice of the small politician, who, instead of studying the best interests of the 
people, trembles lest doing his full duty may cost him a vote, and who is not seldom apt to fear the resentment of the thicves more than that of honest men.-Carl Schurz.

\section{BLACKEST CRIME OF OUR HISTORY.}

The recent devastation by forest fires in Northern Minnesota, Wisconsin and Michigan, pathetically confirms the wisdom and broad-minded forethought of the agitators for forest preservation and restoration, "the forestry cranks." It is announced that "fire bugs are responsible for the fires," and God is thanked for sending timely rains to extinguish a conflagration that threatened appalling consequences. The announcement is a lie, and the thanks are sacrilegious. The state is primarily responsible for the fire, working through its petted and pampered favorites. An attempt is made to compute the loss from these fires, in money; it can not be done. The lumber and timber destroyed, the homes made desolate and the farms laid waste are but trifles in the complication, yet they are all that is computed. The young timber that should have been guarded and nursed into maturity for the use of those to come after us, and the soil that would have supported forests for generations of men yet remote, went out in the smoke and flames of those awful fires. Those who can fully appreciate and correctly estimate the real loss consequent upon the destruction of forests, that we now encourage, are yet unborn. A proper administration of our forests, the enforcement of certain simple regulations, the small expense of a given supervision, the utilization of an infinitesimal percentage of the profits of our forest despoilers would secure ample forests, and cheap and abundant timber for posterity; while under existing conditions treeless wastes of nude and blackened land will be the scroll upon which our children and our children's children will read the record of our indifference, selfishness and greed. Neglect of forests, of their preservation and restoration is one of the blackest crimes of our history.-Farm, Stock and Home.

\section{DESTIROYING OUR WARBLERS.}

- remarkable that in the last quarter of the nineteenth century there should a large numbers in the most enlightened countries in whom the savage spirit survives. For shooting wild birds, often maiming and crippling them, inflicting on them the acutest torture, is no less cruel and brutal than cock fighting of Spain, and the bull and other animal contests of imperial Rome. In many respects it is much more cruel. Birds have a very highly organized nervous system and must be keenly susceptible to pain. Almost everything they do indicates this. Their quick movements, their marvelous ærial evolutions, their attachments, their maternal instincts, their evident enjoyment of the beautiful, and the wonderful powers of song that many possess, all attest their high physical organization and prove the greatness of the cruelty that would ruthlessly deprive them of life. The surprise is greater when we reflect that some men of education, and in other respects of high character, indulge in the so-called sport of shooting innocent birds. It may be sport, but is it not 
the sport of a barbarian and the enjoyment of a savage? No doubt future ages will look on the wanton killing of birds in this period with the same surprise and disgust that we feel on reading the stories of the animal contests in the Roman arena.-Prof. Samuel Aughey.

\section{TIMBER-TESTING MACHINES.}

Already we have "testing machines" to determine the tenacity of the fiber and the influence of different degrees and methods of seasoning. In the government building of the World's Fair, I noted the effects of heavy blows struck at different angles on the same and other varieties of wood. There was demonstrated practically, what some of us at least may have observed, that the qualities of the soil and climatic conditions really enter, so to speak, into the very constituency of the wood. We are certain lumber trees for building purposes, and particularly for cars, bridges, etc., can never be developed on poor or water-soaked soils. We cannot put our waste places to so good a use as to plant trees thereon as shelter-belts, as thickets to economize evaporation. So far they pay, also for fuel. But if we would raise trees for their mechanical utilities, we must give them rich and properly-drained soils.

\section{ROADSIDE TREES IN FRANCE.}

The planting of trees along the public roads of France is considered worthy of statistical mention. At present the total length of public roads in France is 18,750 miles, of which 7,250 are bordered with trees, while 4,500 miles are already being planted, or will shortly be planted. On the remaining 7,000 miles the nature of the soil does not admit of plantations. The number of trees already planted amounts to $2,678,603$, consisting principally of elm, poplar, acacia, plane, ash, sycamore and lime trees.

\section{NEBRASKA FORESTRY.}

Data, as near accurate as may be, show that the acreage in Nebraska since the extinguishment of the Indian title to lands, and the passage of the Kansas-Nebraska act, in 1854 is, in round numbers, about 2,021,543 acres. We have planted about $6,065,689,750$ trees. We reckon 3,000 trees to the acre, 4 feet by 4 . It is safe to say that the spontaneous tree growth in the territory and state since fires have not been permitted to run over the prairies, has increased over the original timber area quite one-half as much as has been planted. Thus the total increased timber area or acreage for the forty years has been, say, 3,032,319 acres.-Ex-Gov. Furnas.

\section{HOW TO MIX.}

Rule 1. The main growth, i. e., the one that occupies the larger part of the ground, must be of a kind that improves soil conditions, namely, a densely foliaged, shade-enduring kind, which does not lose its shading capacity with age.

Rule 2. Densely foliaged kinds may be grouped together, if the slow grower will endure the shade of the rapid grower, or can be protected 
against its supremacy by being planted in larger specimens, or in advance of the former, or in large numbers, or if its gradual killing out after it has served its function of soil cover is not objected to.

Rule 3. Thinly foliaged kinds should never be grouped together where soil humidity is to be preserved, unless no leafy tree can be found to fit the locality.

Rule 4. In grouping light-needing with shade-enduring kinds, the former must be more rapid growers or must otherwise be given an advantage.

Rule 5. The mixing in of the thinly foliaged trees is preferably done singly and not in groups, unless special soil conditions necessitate the latter method.

With such rules and considerations in mind, the proper practice in prairie planting is indicated.-Prof. B. E. Fernow.

\section{FOREST RESERVES IN NEW SOUTH WALES.}

The total forest area of New South Wales, says the Hon. J. P. Hudson, superintendent of the exhibit from that country at the World's Fair, is estimated at about 21,000,000 acres, and 1,013 forest reserves have been proclaimed, covering a total of over $5,600,000$ acres, subdivided in twentyfive districts, each having resident foresters and traveling inspectors whose duty it is to safeguard these forest reserves In 1891 the forest department expended $\$ 119,375$ upon the northern reserve for the conservation of red cedar, and other purposes. As in the United States, so also in New South Wales, Arbor Day has been appointed, on which the children of all the public schools plant trees. There is also a state nursery, consisting of over $1,200,000$ trees, representing over 250 kinds of timber.

\section{ACREAGE RESEIVED IN THE UNITED STATES.}

The forest reservations proclaimed by the President, under the Congressional act of March 1st, 1891, are divided as follows in the different states and territories :

\begin{tabular}{|c|c|c|}
\hline Alaska. & $1,851,520$ & New Mexico............ \\
\hline Arizona..... & 355,520 & Oregon. $\ldots \ldots \ldots \ldots \ldots$ \\
\hline California............. & $6,238,729$ & 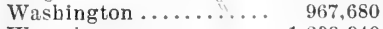 \\
\hline Colorado.............. & $3.101,360$ & 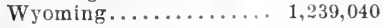 \\
\hline
\end{tabular}

ECONOMIZING SNOW.

"Mr. R. W. Piper, in his Trees of America, states that an unobstructed warm wind will dissolve the snow more than ten times as fast as when protected from the wind, the temperature being the same." The snow that falls on the open prairie has little or no continuity, the wind sweeps it away, leaving the ground to freeze solid and deep, and drifting it into the ravines and 'other places where it may be useless to the farm. The frost-crust being impermeable, and the melting rapid in the early spring, the water rushes away in floods. If farmers would have the benefits of the snow-mulch, wind-breaks should be numerous, and at different angles, so that the snow-flakes will eddy on their fields. The action of the snow in the woods is different. There it remains generally level, pressed over the litter, infilled with air like so much fur, that protects against undue freezing of the 
ground, keeping it open for percolation when the snow melts. The forestcover greatly retards the melting process, lengthening the time to filter down. Being a poor conductor of heat, snow melts from beneath, hence its upper stratum has a tendency to glide forward, in so doing, it gathers up in the woods the leaves and sticks; and the slushy stuff forms itself into little dams at the base of the trees and around the logs and stones, making water-pools even on the hill-sides. The water thus held back, percolates along the roots, saturating all the ground to complete fulness. The result is a subterranean water conservation by whose drainage it reappears in summer for vegetative growth. Strange to say, state and national legislature tolerates and encourages a business policy that pays no attention to this conservative arrangement of nature.

\section{THERMAL ALTERNATIONS.}

Like all other plants, the trees are slow but great absorbers of sun-heat from the air and other sources. The heat-storing process may be so intense and extensive during the germinating and flowering season as to result at night in an atmospheric chill. The German forester Ney, maintains that "the unreasonable frosts of mid-May in Europe, are due to the amount of heat absorbed by plants at that season." The alternations from cold to heat, and from heat to cold, are interchangeable forces by which precipitation becomes possible, and the agent which nature specially employs in these operations, is the forest making dew ana mist, and snow and rain.

\section{PLANTS OR TREES PER ACRE.}

The following table will be found very convenient, as giving the number of plants or trees on an acre, at various distances apart:

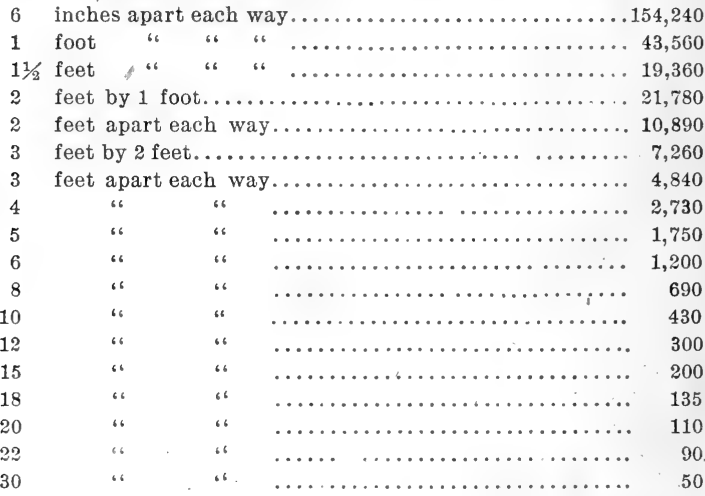


Rows six feet apart, and trees one foot apart in the row, 7,315 trees per acre.

Rows eight feet apart, and one foot apart in the row, 5,434 trees per acre.

Rows ten feet apart, and one foot apart in the row, 4,389 trees per acre.

One mile of wind-breaks or shelter belt requires 5,280 trees or cuttings for a single row, one foot apart in the row.

\section{MECHANISM OF A FLOWER.}

The chief parts of a flower are its stamens and pistils in its center. Given these sex-organs, though the petals, color and perfume be wanting, yet we have a true seed-bearing flower. The top of each stamen is a little box of pollen; the bottom of each pistil is a little box of seed germs. The pollen ripens slowly in the stamen case, but, becoming ripe, it must be released and reach the seed germ. The top of each pistil is a stigma, or little sticky cushion, to which the pollen dust will be likely to adhere if brought in contact with it. Once landed on the stigma the pollen seed bursts and sends a minute aliment of growth down the style of the pistil to the seed germs lying in the box at its base. Thus the seed germs are fertilized; they begin to grow into seeds. Unless these new seeds were constantly reproduced, the world of plants must soon end, and therewith also the animal world. It is the aim of the plant to assume the continuance of its kind by getting the pollen dust safely landed on the pistil.

\section{SEX-COMMERCE OF PLANTS.}

But helpfulness is needed from some quarter. The wind comes into play, but often fails to do the work. We must understand that stamen flowers and pistil flowers are not always on the same plants, nor always on the same tree. And we should appreciate the laws of evolution, alike applicable to plants as to the animal kingdom, that we have the best improved kinds when the pollen comes to the pistil from some other flower than its own. As the pollen is a commodity of sex-commerce, it must be carried about. What agency has nature provided to meet this necessity? Why, the honey-seeking insects.

\section{INSECTS COLLECTING POLLEN.}

Most insects have a long tongue or pipe for eating or drinking. This pipe may shut up like a telescope or coil up like a watch spring. With this long tube the insect can poke into the slim cups, horns and folds of flowers of varied shapes. Who that has seen a big bee busy in a lily or trumpet flower, an ant come crawling from the tiny throat of a thyme 
blossom, a wasp feeding on a honeysuckle or pink, a bumble-bee feasting on a wild rose, until his velvet coat is covered with golden dust, can doubt the efficiency of the insect in collecting pollen?

\section{INSECT PARTNERSIIP.}

In every business all the partners must have some profit. The insect partner in flower-increasing has honey for bis gains. As the pollen ripens the flower secretes a drop of honey for the insect partner. The ripe pollen and the ready honey are simultaneous. Just at this crisis, too, the hues of the flower are gayest to lure the insect eye, and the perfume is also most penetrating to call the attention of the winged-partner in the flower business.

\section{FRUCTIFYING THE SEED GERMS.}

Into the blossom goes the insect, and comes out dusty with pollen; its legs, body, wings are covered with the minute precious grains. Off then to another flower, and evidently as it creeps into the remote honey drops, it rubs against the sticky stigma of the pistil and leaves thereon the desired pollen to fructify the waiting seed germs.

SAME KIND OF FLOWERS.

But stay, the pollen of a rose will not make the seed germs of a lily grow; the tulip can do nothing with the pollen from a honeysuckle; the pollen of a buttercup can only be used by a buttercup. To do any good, the pollen must go from one flower of a kind to another of the same kind.

INSECTS NOT ERRATIC,

How can this safe conveyance be assumed by any creature so erratic as an insect? But insects are not so erratic as they seem. Watch them. They have a singular and fixed habit in feeding. They go always from flowers of a kind to other flowers of the same kind. Watch a bee. It goes from clover to clover, not from clover to daisy. The butterfly flits here and there, but watch it settle. If it begins with a pink it keeps on with pinks. If it begins with golden rod, it keeps on with golden rod. If I have in my garden only one petunia, the butterfly which feeds upon that will fly over the fence for more petunias, and will not be beguiled on that round by my sweet peas.

UNALTERABLE HABIT.

God has fixed this unalterable habit in insects. They feed for a long time on the same kind of flowers, and thus convey pollen where it is needed and can be used. The butterfly, which serves itself with its feet for standing, but almost never for walking, is one of the most active partners of the flower. Because, being almost wholly a flying insect, the butterfly is in no danger of wasting pollen by rubbing it off on leaves or stems, where it must perish. Loaded with pollen from one flower, the butterfly goes speedily to the waiting heart of another flower. Besides, it eats only honey and never pollen, and it spends its entire time revelling from bloom to blcom, while its long tube enables it to feast upon every flower that grows. 


\section{CROSS FERTILIZATION.}

The production of seeds by the transference of pollen from the blossom upon which it ripens to the seed germs of some other blossom, is called cross-fertilization. The falling of the pollen upon the pistil of the same flower is called self-fertilization. The prevention of self-fertilization is secured by many wonderful devices, while cross-fertilization seems needful, not only for the normal development, but even to the continuance of the vegetable kingdom. Among other means to this preventive end is the curious difference in time between the ripening of the pollen-sac and of the seed germs upon the same flower. There is but one time in the history of the pollen when it can fertilize the seed, that is when the pollen is entirely ripe, but while its cadence has not yet begun. Also, the seed germ can only be fertilized when it has reached, not passed, its proper stage of maturity. Now, the critical moments of the due ripeners of germ and pollen are seldom simultaneous in the flower. The pollen-sac discharges its treasure to be insect-borne to some more mature blossom; the seed germ delays its ripening and awaits the Danæ-shower from other laggard bloom.-Julia McNair Wright, in Science News.

\section{LIGHT INFLUENCES.}

In the earliest stages of life the little seedlings of most trees require partial shade and are quite sensitive in regard to light conditions. Some have such a small range of light and shade endurance that, while there may be millions of little seedlings sprouted, they will all perish if some of the mother trees are not removed and more light given; and they will perish equally if the old growth is removed too suddenly and the delicate leaf structure, under the influence of direct sunlight, is made to exercise its functions beyond its capacity.

\section{STRUGGLING FOR IIGHT.}

Left to itself, as the forest grows up and as the individual trees develop, each trying to hold its ground and struggling for light, there is a natural thinning taking place, some trees lagging behind in growth and being shaded out, until in old age only as many trees remain as can occupy the ground without incommoding each other. This struggle among the individuals goes on during their entire life. Some few shoot ahead, perhaps because of a stronger constitution or some favorable external cause, and overtower their neighbors; these, lagging behind, fall more and more under the shading influences of their stronger neighbors until entirely suppressed, when they only vegetate until they die, while the struggle continues among the dominant class and is never ended in a forest that is utilized at the proper time by man. 


\section{BATTLING FOR MASTERY.}

The differentiation into dominant growth and laggards takes place in general earlier and more decidedly on strong soils, also in light-needing sooner than in shade-enduring species, which last keep up an even struggle much longer than the former, so that it is difficult to say which will finally.win.

\section{ASSISTING NATURE.}

It is to give direction and assist in this struggle, to hasten its results, to obviate, if possible, useless expenditure of energy by timely interference that the forester steps in with the ax. For the natural thinning, as a rule, does not progress satisfactorily for the best quantitative and qualitative development, and hence it is assisted by the forester, it being well understood that there is a larger total and more valuable product to be had with a smaller number of individuals through better development of the latter.

\section{NUMERICAJ, SCALE.}

It is the number of trees that yield the best result, not the greatest number that we try to keep growing. What this best number is, depends naturally on the kind of tree; it changes also with age, as the trees need more room, and with soil and situation. In the average we would not be far out of the way to require per tree in the twentieth year 10 square feet, in the fortieth year, 40; in the sixtieth year, 100; in the eightieth year, 125; and in the one hundreth year, 160 square feet growing space, or 4,300 , $1,100,435,350$, and 270 trees per acre, respectively, at the ages noted, would represent about the proper average condition of growth. There are from 50 to 75 per cent more shade-enduring trees possible on an acre than light-needing; more trees on poorer soils, sometimes two to four times as many, than on good soils, and more in the valley, sometimes double that of the higher elevations; so that while a pine growth of, say, 60 years may show 500 trees to the acre, a beech growth may contain 750 trees under the same conditions.-Prof. B. E. Fernow.

\section{EFFECTS OF LIGHT COIORS.}

Experimentation has demonstrated that plants of varied species differ in respect to the rays of light which they absorb or reject. About twentyfive years ago, M. Bert reported to the French Academy of Sciences the results of his experiments under the influence of colored lights on twenty-five species of growing plants, belonging to as many families, and exposed to the same conditions. He found

First-That green is almost as obstructive as total darkness.

Second-That red is very injurious, but not so much s $\rho$ as green, and that it causes plants to elongate in a singular manner.

Third-That yellow is less injurious than the above, but more so than blue.

Fourth-That any one of the colors has a bad effect on plants, and that their union in the proportion that forms white light is necessary to vegetable health. 


\section{REVELATIONS OF THE SPECTROSCOPE.}

It has been discovered by the spectroscope, that light, when traversing a leaf, shows an abundance of green and red rays, which are not utilized by the plant. This, doubtless, accounts for the fact that some young trees will not live in the dense shade of the parent tree. Trees differ, too, in the quality of the light that is absorbed and transmitted. Doubtless the mosses and liverworts enjoy the red rays, for they will thrive luxuriantly under the densest forest shade. Some of our forest trees, the ash for instance, will live under the shade of other trees, where a different species will die. Some of the rays transmitted, for instance, by the box elder, whose shade predominates, may be absorbed by the ash. A beech will grow under the shade of an oak better than the young oak itself. In such cases different species of trees mutually support each other. It has been observed that the box elder does less injury to grass and grain under its shade than some other species. The elder seems to favor the growth of grass, while the broad-spreading butternut excels most trees as a monopolist-it injures both grain and grass.

\section{EFFECT OF TREE-SHADOWS.}

The effect of the shadows of different species of trees elongated, for instance, in the morning sun, is very marked. Though the shadows may be equally dense, the injury on cultivated plants is very unlike. Whether there is any peculiar chemical action, imparted by the tree, cast forward into and with the shadow, we know not; the more plausible inference is, on the data here given, that certain rays are absorbed more by the leaves of one tree than another. These experimentations corroborate our observations, demonstrating that trees do better where a variety of species are growing side by side, than they do under our set method of having only one species or variety on the lot.

\section{WORK OF THE TREES.}

"The tree of the field is man's life," said the inspired law-giver of the Hebrews. In this short sentence, written over three thousand years ago, is condensed all that trees do for us. They give us life. Without them we could not live. In destroying them we destroy our means of existence. To the outward eye a tree is a very plain, simple thing, with its root, stem and branch, wood, bark and leaf, given to us to provide shade and fruit, and to gratify our sense for the beautiful with its form and color. But much more than this is there. There are invisible powers working ceaselessly within and around it, which control and direct the machinery of the world. As we study the origin and life of a tree, we learn with wonder the mighty preparation made for its coming on earth, and the 
abundant provision for its continuance. We see, as Maurice de Guerin wrote, "Nature all absorbed in the mystery of her maternities," and realize that the gigantic forces of the world which, for ages of æons, were busy upon the earth, have been preparing it for the growth of trees. The forest was the finishing touch put to the earth, and with it the dwelling-place, prepared by God for man; was declared complete.

\section{EVOLUTIONAL GROWTH.}

The provision in nature for the renewal and continuance of the treegrowth is very remarkable. When certain requisite conditions of climate are present, the hardest rock is as certain to be overgrown with wood as the most fertile plain. Lichens and mosses first prepare the way by retaining the moisture of rains and dews and bringing it to act with the gases evolved from their own organic processes in decomposing the surface of the rocks they cover; they arrest and confine the dust which the wind scatters over them, and their final decay adds new material to the soil already half formed beneath and upon them. A very thin stratum of earth is sufficient for the germination of seeds of the hardier trees, whose roots are often found in direct contact with the rock, and which seem to want but little more from the earth than the mechanical conditions favorable to the penetration of their roots and the support of their trunks in an upright position, the whole of their substance being derived directly or indirectly from the atmosphere. These prepare the way for other trees and plants by deepening and enriching the soil through the decomposition of their own foliage. This elaborate and careful provision of nature to insure the permanency of trees indicates that they must have a work to perform which has its effect upon all the conditions of the earth.-Prof. N. H. Eggleston.

\section{MOISTURE PRODUCTS.}

It is stated by reliable authorities who have visited Russia, that its topographical and climatic conditions in general are very much like our Northwestern prairies, and the flora of both countries largely corresponding. Possibly, it may be found that their meteoric phenomena, local influences allowed, are counterparts of each other.

In his World's Fair report of Russian "Agriculture and Forestry," John Martin Crawford, United States Consul General to Russia, informs us that "the black-earth governments of Russia (a central southerly region near, or comprising Moscow) suffer more frequently from drouths than the northern governments, although in the former, the precipitation of moisture is much more copious." In the northern region referred to, where the precipitation is considerably less, "drouths are rare, and the harvests of ten suffer from an overabundance of moisture." This seems to be a meteoric paradox. But Mr. Crawford lucidly explains it all by stating, that at the low temperature in the governments of northern Russia, "a much smaller quantity of moisture is sufficient for the slower evaporation. Besides this, the long winters, and the presence of large lakes, swamps and forests, favor the existence of a greater quantity of moisture." 
Here is demonstrated the fact, that the dependencies of plants are not so much upon precipitation per se as upon the convective humidity of the atmosphere. The wild and improperly cultivated soil of our prairies is usually compacted by excessive heat and heavy rains, when they do fall; hence the precipitation is soon lost by "running away." As before shown, surface stirring of the soil fits it for moisture absorption and capillary action. But this will not save us from drouths and crop failures, unless there is enough moisture to supply the needs of our plants, either by root or leaf imbibation, or, better, by both.

Meteorologically speaking, northern Russia does doubtless have an advantage over us of the Northwest. Her forests there are vaster than ours. Aside from great interior lakes and undrained swamps, she has the humid influences of the Baltic and White Seas, and the cooling winds of the Arctic Ocean, converting the vapors into mists and dews.

But it is possible in human enterprise to make our Northwest equal to, if not surpass northern Russia in water facilities. Lake Superior is our Baltic Sea. Our chain of great lakes in northern Minnesota, and our swamp lands, are, with economic appliances, ample for all our needs. The salutary influences of the Arctic Ocean are equally ours to command. We still have the remnant of a forest. If our Minnesota would "rise and shine," the raided forest must be repaired. This done-and done immediately, or lose forever the successful point-and next the canalization of the state, bringing a goodly portion of Lake Superior "this way" for irrigational and navigational purposes, and the canalization of the great plains from the Missouri to the Mississippi, aiding their forestation; when this is done, as our very necessity, we shall have evolved moisture ample for the needs of our agriculture and fruit raising, not then surpassed by Russia or any part of the globe in the north temperate zone.

\section{WOOD CONSUMPTION FOR MINING.}

"It is safe to say that the estimate of a total annual consumption for mining purposes in the United States is $150,000,000$ cubic feet of wood. In comparison with the general consumption of wood in the United States, which must amount annually to over 20,000,000,000 cubic feet, these figures do not allow us to point out the mining industry as a leading factor of the exhaustion of our timber supplies. Yet in some regions the question of the supply of mining timber has already attained sufficient importance to call for its consideration. In the Pennsylvania coal region the near-by supply is rapidly diminishing, making longer haulage necessary. In fact, the companies and operators reporting to the Forestry Division draw their supplies mostly thirty to forty miles, and some of them eighty miles, to their fields of operation. Even from the famous timber region of northern Michigan, this state of affairs is reported. In Utah, the scanty home supply would have been used up long ago but for some importation of California timber, upon which also the Nevada mines now rely almost entirely. The Montana mines are using enormous quantities, much more than can be furnished for any length of time by the limited 
home supplies. In Butte City, the great Anaconda mine alone consumed last year over 1,000,000 cubic feet of mining and building timber; and the consumption of firewood for smelting, etc., in this one camp, was estimated at a round 300,000 cords per annum. While to the mine superintendent other questions of management may seem more important at present, the question of timbering with regard to economy in the use of the material may soon become momentous, as the general lumber market is bound to advance in price with increased demand and decreased supply, for the reproduction of which nothing but nature's slow processes are relied upon."

\section{PLEASURE GROUNDS.}

It is easily within the memory of those living that pleasure grounds were provided by the large cities of the world for the recreation of the people. Until recent times the common people were looked upon as of too little importance, or as having too little respite from their daily toil, for any public provision to be made for their healthful recreation and pleasure. The large tracts of forests and parks in Europe, whether owned by the state or by private citizens, were kept for pleasure and hunting grounds for use only of the nobility and gentry-the privileged few. Within recent times many of these crown lands have been utilized as parks for the people, whose growing importance and needs command respect and consideration, even under monarchial government. The recent European parks were, as a rule, old private parks, or crown lands, now made free and adapted to public use. And for this purpose they have been improved and so treated as to bring out all the possibilities of landscape beauty.-Warren Higley.

\section{TURTLE MOUNTAIN RESERVR:}

Under the leadership of Hon. W. W. Barrett, superintendent of irrigation and forestry, North Dakota, a forestry reserve will eventually be located at Turtle Mountain, the watershed heights of the far north. Nothing is more essential for the interests of agriculture in all that region so famous for its wheat production. We must have this important link put into the great chain of reserves ere long to be stretched from the Atlantic to the Pacific. 


\section{EDUCATIVE.}

\section{FOREST ORGANIZATIONS.}

Forestry is now recognized by the general government as well as by the governments of a number of states. With active forestry associations in Pennsylvania, New York, Ohio, Minnesota, Kentucky and Colorado, and organizations closely allied in interest in other states; with the forestry division of the Department of Agriculture at Washington, seeking to disseminate knowledge as to arboriculture and the utilization of various woods; with special commissions studying the forest problems of Pennsylvania, New York, New Hampshire, Vermont, Maine and Michigan, added to a widespread influence resulting from the excellent exhibition of forest products and forest development in connection with the World's Columbian Exposition at Chicago, we see much of encouragement. To these may be added the public meetings of the American Forestry Association, the Pennsylvania Forestry Association, and the other kindred societies, the Forestry Congress held in Chicago in October, the growing observance of Arbor Day in various states, and the interest exhibited by those who are educating the youth of to-day, making a resume which marks real progress.Forest Leaves.

By the educational instrumentality of the American Forestry Association, not only has a rational forest policy been formulated, but a congressional enactment secured, March 1, 1891, whereby the President has proclaimed a series of forest reservations, located in the Rocky Mountain and Pacific regions, aggregating over $17,000,000$ acres. Within a decade scientific forestry has gained such an impetus, the United States civil engineers and the officials of the Weather Bureau are experimenting to know what part the forests perform in precipitation and water distribution. The American Association for the Advancement of Science is actively coöperating, and so the horticultural societies of different states. Many influential monthlies, weeklies and dailies are heartily engaged in the good work. Public sentiment is pressing Congress to do something more definite and positive to control the forest cover of the United States.

ARBOR DAY.

Arbor Day was originated by Hon. J. Sterling Morton, secretary of the United States Department of Agriculture, who, in 1872, then governor of Nebraska, introduced a resolution at a meeting of the State Board of Agriculture, which was unanimously adopted, setting apart the 10th day of 
April as a day consecrated to tree planting, and offering a special premium for the proper planting of the largest number of trees. It is stated that on that day over a million trees were planted in Nebraska. In 1874 his successor, Gov. Robert W. Furnas, issued the first Arbor Day proclamation which was generally observed, and the next year the legislature of that state made it a legal holiday in Nebraska.

Minnesota followed the example. Under the leadership of Leonard B. Hodges, then secretary, the State Forestry Association offered premiums for tree planting on our first Arbor Day, May 1, 1876. The responses of the people were wonderful indeed. Over a million trees were planted for prizes alone.

The application of the grand work to the schools was first named and projected in Minnesota. In August, 1882, the American Forestry Association (international) held its annual meeting in St. Paul, when Prof. B. G. Northrop, of Connecticut, originator of "Village Improvement Societies" (by tree culture), successfully introduced a resolution favoring the observance of Arbor Day in all the schools of the states and Canada. Minnesota again at the front, Hon. L. Hubbard, in 1885, was the first governor of our state who proclaimed Arbor Day under the school regime, followed in the succeeding administrations by Governors McGill, Merriam and Nelson, coöperated with by Prof. D. L. Keihle, superintendent of public instruction, and equally earnest by his successor, Prof. W. W. Pendergast, and county superintendents and principals of schools generally throughout the state. Since these initial steps Arbor Day is annually observed in nearly all the states and territories, Canada, Europe, Australia, New Zealand, South Africa, and will soon be world-wide.

The sylvan anniversary means more than mere sentiment, or even an understanding of the benefits derived from tree planting. It involves the discipline of foresight. Tree culture and waiting for growth extending through a life-time and thence to other generations till it becomes a factor of patriotic history, gravitates the mind and heart to stability of purpose and establishes character-building on enduring principles.

EXTENSION OF TIIE WORK.

Heretofore the observance of the day has been the planting of trees on the farms and along the streets and highways and streams, and in the cemeteries and parks and lawns of the homes and schools and churches. All this is most praiseworthy; but why not extend its usefulness in saving young, native trees? The duty in hand is to eradicate the inherited habit of tree destruction without respect to utility. It is no uncommon practice for boys, and men, too, to cut down fine cherries, butternuts and other trees just for the fruit, thoughtless as to future supplies. If anything will tend to eradicate the vandal instinct, it is Arbor Day observed by the woodland schools. Where the native woods have been cleared for towns and farms is room enough for replanting the valuable species, such as the oaks, pines, spruces and maples, about as extensively as on the prairies that are mostly monopolized for cereal crops. Make the saving of trees inseparable from planting trees, and Arbor Day becomes a permanent success constantly growing in public interest. 


\section{THE AFTER CARE.}

Where the work is not properly systematized under some official head, sheer neglect is apt to follow the planting. Better plant even but one tree and make it live than plant a hundred to die before the year has expired. There should be judicious supervision over the trees during the entire season.

\section{REGISTRY OF TIIE TREES.}

An excellent plan is to have a registry of the trees kept in the school. archives, and the next year have a report sent to the state auditor, giving the species and number of trees then living, to be entered in an Arbor Day register for future reference. It is to be hoped that our next legislature will systematize some such plan by legalizing Arbor Day, as in some other states, thus making it more efficient in its observance, and furnishing forestry statistics for the state.

\section{DRAFT OF THE PLANTED TLEES.}

Where the locality warrants, the trees being in groups or rows, as in a school yard, it is well to have a draft or map of the spot, representing all the trees and flowering shrubs with the names attached, each pupil owning a tree. The draft should then be framed and hung up in the library room.

\section{PRELIMINARY EXERCISES.}

Prof. N. H. Eggleston, of the Forestry Division of Agriculture, at Washington, D. C., suggests for outdoor ceremony prior to planting, that the children "march along the streets to the music of their own familiar songs, wearing such scarfs and badges as they choose to decorate themselves with, and carrying aloft their banners with the pride of young patriots and scholars." And for indoors a programme like this:

The reading of the laws of the state relating to Arbor Day; reading of letters from forestry friends living abroad; brief addresses and essays on the subject of forestry; voting for the tree or flower that shall be the emblem of the school for the year; "to facilitate the voting, a blackboard facing the pupils during the exercises with a few drawings of trees and flowers, each with a characteristic attribute printed beneath it. The voting may be expeditiously performed by pointing to the drawings."

\section{FORESTRY IN OUR SCHOOLS.}

While every leading nation in Europe has its school or schools of forestry, there is not one such, strictly speaking, in the United States. There is a growing demand for such institutions. To pave the way, American foresters in the states and Canada urge the establishment of a rudimental system of forestry in the higher grades of all our public schools. The times are ripe for it. Already a large number of our teachers are interesting their pupils on this line of education, and it is having a most salutary effect. If our legislature would put rudimental forestry in our educational curriculum, it would unquestionably meet a great and growing demand and evoke a hearty coöperation over the entire statc. Minnesota leading, other 
states would soon follow. N. F. Brand, a graduate of the Schoel of Agriculture, is sanguine that the instruction there imparted tends to inspire "aspirations for a fuller forestry education and a better administration of our forests." He thinks that the work of St. Anthony "may be the seed from which a good school of forestry may some time spring up in Minnesota."

\section{ORGANIZING THE SCHOOLS.}

In 1892, Hon. W. W. Barrett, superintendent of irrigation and forestry, North Dakota, temporarily enlisted the school children of that state in collecting tree seeds for the Columbian Exposition at Chicago, Ill. The responses were so efficient it is now proposed to institute a permanent organization, entitled

\section{THE STATE SOCIETY OF SYLVITONS.}

ARTICLE I.

Section 1. The officers of the State Society of Sylvitons shall consist of a president, vice-president, secretary, treasurer and executive committef, to audit accounts and perform other duties for said society, and a vicepresident in each county. Said officers shall be elected by the majority ballots of delegates at each annual convention, each local society being entitled to one delegate. The executive committee appointed by a preliminary meeting shall select said officers protem, holding their office until their successors are elected at the first regular convention, when by a twothirds vete this constitution may be altered or amended.

\section{OBJECT OF THE STATE ORgaNIZATION.}

SEc. 2. The object of the State Society of Sylvitons shall be to unite the educational forces of the state by means of like local societies, represented in this body, for forestry work and its practical application to the betterment of climatic, meteorological, agricultural and horticultural conditions, wherein are involved the best interests of the community.

AWARDS OF MERIT.

SEc. 3. This society may grant awards of merit or diplomas; to any Sylviton, or Society of Sylvitons in the state, or elsewhere, that practically demonstrates superior proficiency in tree or forest culture, or in best collection of forest products, or best original essay on forestry, botany, irrigation, meteorology, or other correlative subject; and such awards shall be signed under seal by the president and secretary.

\section{LOCAL SOCIETIES.}

ART. II.

Sectron 1. There may be a Society of Sylvitons in every school district or school of any kind within the state, and it shall have the right to regulave its own affairs in harmony with the constitution and scope of the state society, in this form: 
The undersigned, members of School District No. town

county of —_, state of _—_ hereby organize ourselves into a body corporate, to be known as the Society of Sylvitons.

OBJECTS DEFINED.

SEc. 2. The objects of this society shall be: (1) to make forestry a life study in practical application; (2) to arrange for and properly observe Arbor Day; (3) to collect and neatly label specimens of woods, barks, leaves, twigs or branches, roots, flowers, seeds and fruits of our indigenous flora, together with geological and archæological specimens, for a school cabinet or museum of the same, and to procure exchanges with other societies and individuals wherever feasible; (4) to coöperate with the state movement for tree culture in a general way, and especially in applying such culture to our own environments; (5) to procure legislative enactments for the better protection of our native forests and domestic trees; (6) to encourage the establishment of parks, state and national forest reservations and irrigation systems; (7) to acquaint ourselves with the science of botany for practical uses, and to enlist the coöperation of the press, churches and other institutions in whatever is favorable to these objects; (8) to acquaint ourselves with a knowledge of our birds and their habit and usefulness, with a view to defend them against all robbery of their nests and all unkind treatment, so that they will delight to stay with us and bless us with their melodies and their destruction of injurious insects; also to procure enactments by our legislature better protecting our birds.

OFFICERS AND THEIR DUTIES.

ART. III.

SECTION 1. The officers of this society shall consist of a president, vicepresident, treasurer, secretary, and an exccutive committee having duties as aforesaid, and shall be elected annually by ballot.

SEC. 2. The duties of the president or vice-president shall be the same as those of any other ethical society, and said officers shall preside strictly according to parliamentary rules.

SEC. 3. The duties of the treasurer shall be to collect and hold in trust all funds of the society, subject to its order, vouched for by the president and secretary, and approved by the executive committee.

SEc. 4. The secretary of this society shall keep a faithful record of its doings, and report the same at the nex meeting, and shall neatly file in a separate book all essays and other valuable papers belonging to the søciety, and shall attend to all necessary correspondence with other like societies, and shall register the species and number of trees planted on Arbor Day under the management of this society, mentioning their localities, and shall report the same and the name of the person to whose care the plants are entrusted, and the number and species of trees and shrubs living at least one month before the next observance of Arbor Day, to the president of the State Society of Sylvitons, and for North Dakota to the superintendent of irrigation and forestry, and for Minnesota to the secretary of the State Forestry Association, and for any other state to like authorities, where the Sylviton system may be established. 
SEC. 5. The several school or district societies of Sylvitons may annually hold delegate conventions in their special towns and counties, officered as herein designated for the furtherance of these objects.

\section{NO SALARIES.}

ART. IV.

SeCtion 1. No officer of state or local society shall receive pay for services, except bare cost for duties performed, and then only when approved by the executive board.

SEc. 2. All moneys of this society shall be expended as voted for at any regular meeting, but in every instance for the sole benefit of this society.

\section{REGULAR MEETINGS.}

ART. V.

Section 1. The meetings of this society shall be held at such times and in such places as may be voted for, and their exercises shall consist of verbal or written reports of personal observations and experimentations along the lines herein mentioned; also appropriate lectures, essays, discussions, music and songs.

\section{MEMBERSHIP.}

ART. VI.

Section 1. Any person under twenty-one years of age may become a member of this society by signing this constitution and paying the required fee; other persons over twenty-one may become honorary members by a majority vote of the society.

\section{AMENDMENTS AND BY-IAWS.}

ART. VII.

Section 1. This constitution may be amended at any regular meeting, after one month's previous notice, by a two-thirds vote of the members, and by-laws instituted as may be deemed essential to order and success.

\section{CHRISTMAS TREES.}

There is something peculiarly captivating in using evergreen trees, on which to hang our Christmas presents. It seems almost sacrilegious to interfere with the custom. But practical economy must take the precedence of mere emblems, however beautiful they may be.

Tbe fact of the matter is this, that millions of the most promising spruces and bail:ams, growing in our northern woods, are annually cut and shipped by car loads to the cities and villages of the state and those of the Dakotas. The hurt done to our native conifers is almost equal that of a sweeping forest fire. There is no religion in thus robbing our already riddled woodlands of our very best young evergreens so much needed for the future. It is a kind of a "sacred vandalism" that should be abrogated. The preservation of these trees for water conservation, climatic healthfulness and timber use in the years to come, is our first religious duty. Let us substitute something for the trees that will serve our purpose equally as well. 


\section{INDEX.}

PAgr.

Act to Protect Forestry from Fires ....................... 59

Ash Family, White, Red, Black, Blue, Green...................12-13

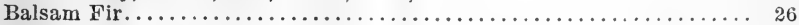

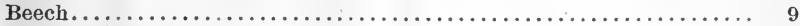

Biltmore Forest..................................... 91

Birch Family, Black, Yellow, Red, Canoe....................14-16

Birds, Insectivorous, Planting Forests. ......................

Cedar, White or Arbor Vitæe, Red...................... 27

Cherry, Wild Black............................... 28

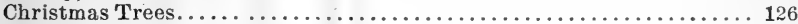

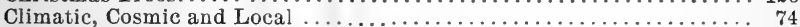

Copying Nature's Method of Forestation.................... 45

Cranberry Agriculture............................. 55

Cultivation of Trees............................... 41

Deforestation and Cyclones, Hailstorms, Neutralizer of ............ 83

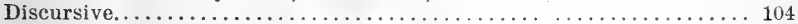

Do Forests Promote Rainfall?...................... 77

Economic, Wild Conditions, Etc......................... 54

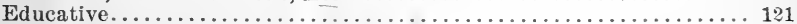

Elm Family, White, Red, Rock or Cork..................... $9-10$

Entomologic, Bark Insects. Prof. Lugger................ 47

Evaporation................................... 91

Evergreens, How to Treat Plants and Seeds.................42-43

Evolution of Moisture............................ 73

Expense Account.. ............................... 4

Facts to Consider....................................

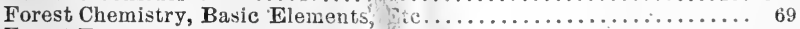

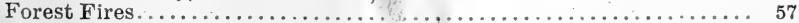

Forest Isotherm................................... 83

Forest Organizations........................... 121-124

Government Control of Forests, Testimonia!, Etc................ 89

Governmental Income of Forests....................... 95

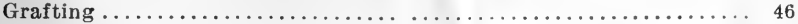

Great Plains, Foresting............................ 85

Hardy Shrubs, Hazel, High Bush Cranberry, Buffalo Berry, Etc... . 29-30

Hedges, From Seeds. Prof. Pendergast.................... 39

Hedge Plants, Buckthorn, Prickly Ash, Jersey Tea, Etc...........30-31

Hickory, Shell-bark, Pig-nut, Bitter-nut......................20-21

Hornbeam or Ironwood, Hop, Water Beech.................. 8-9

How to Manage Seeds, Seedlings and Cuttings............... 33

How to Save the Trees ................................ 104-105

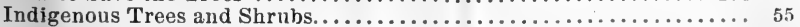

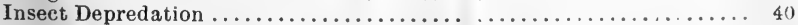

Insects, Injurious and Friendly......................... 51

Irrigation, Water Needed, Crops by, Initial Step.............. 99-102

Judas Tree............................................ 
Kentucky Coffee Tree.

Larch, American, European............................... 26

Letter to the Governor............................... 3

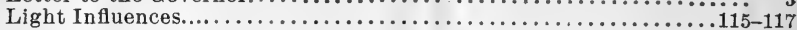

Linden Family, Basswood, Lime, Whitewood .................... 11

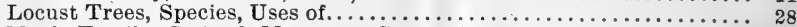

Maple Family, Striped, Mountain, Sugar, Ash-leaved, White, Red ..16-19

Mechanism of a Flower................................113-115

Mesabi Range, Climatic Effects of....................... 76

New Forest Methods, Profits of........................... 90

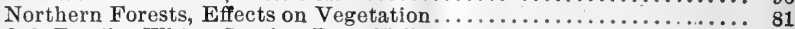

Oak Family, White, Scarlet, Post, Yellow, Chestnut, Burr, Jack, Gray,

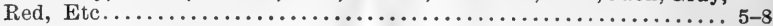

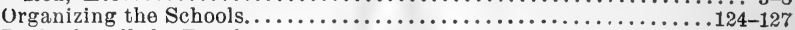

Parks for all the People............................... 56

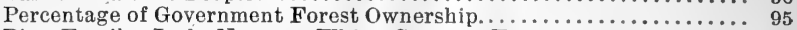

Pine Family, Jack, Norway, White, Spruces, Etc...............24-27

Planting Trees, General Directions for........................ . 36

Plants or Trees per Acre............................. 112-113

Poplars, Aspens, Tacamahac, Balm of Gilead, White, Cotton wood, Etc.22-24

Prairie and Forestal Breezes............................. 76

Precipitation, Fortuitous, Laws of .................. 75-78

Reserve System, New Base, Petition for.................. 96-97

Reservations Bill before Congress........................ 98

Reservoirs, Where Constructed, Area, Etc................... 99-100

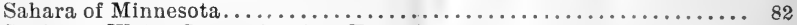

Sanitary, Water Contamination, Etc................................. 86

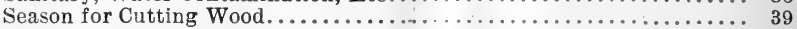

Seeds, Selection, Preservation, Covering of, Etc....................33-36

Soil, How to Manage................................... $49-42$

Snowdrifts, Windrows, Mantle of.......................

Spruces, Black, White, Hemlock, Etc.....................25-26

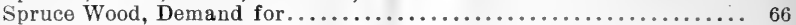

Succession of Forest Growth............................. 105-106

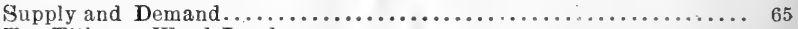

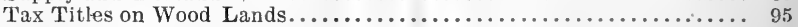

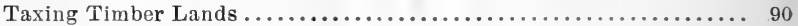

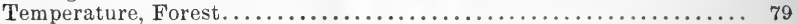

Thinning and Pruning................................ 45

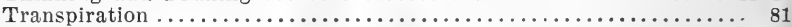

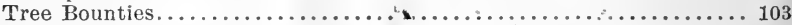

Tree Planting in Red River Valley.. ................... 67

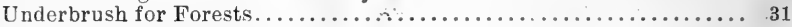

Utilizing Our Surplus Woods.........................63-64

Vines and Climbing Shrubs............................. 32

Walnut Family, Black, Butternut, Hickories.................. 19-21

Water Areas, Climatic Effects of .......................... 76

Wastes, Reckless, Floods and Fires..................... 57

Willows, Black, Almond-leaved, White, Russian, Etc.. ..........21-22

Winds, Force of, Trend of . . . . . . . . . . . . . . . . . . . . .

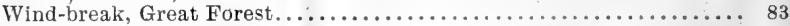

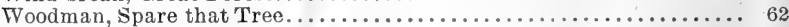

Wounds on Trees, Healing Methods....................... 45

Work of the Trees.................................... 117-120

Zoölogy, Forests, Hawk, Owl, Game Animals and Birds...........52-53 


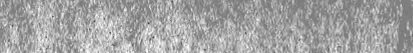

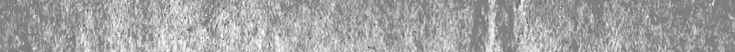

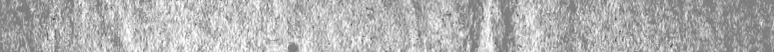

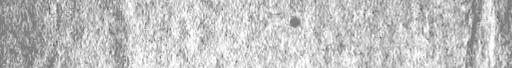

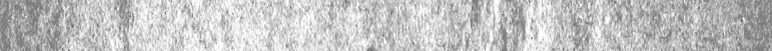
W.

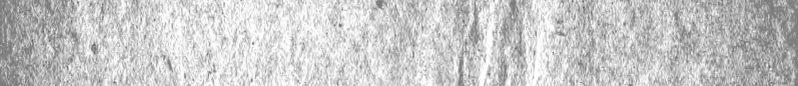

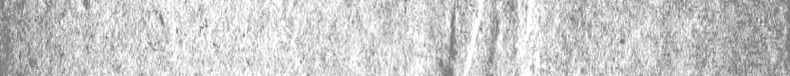
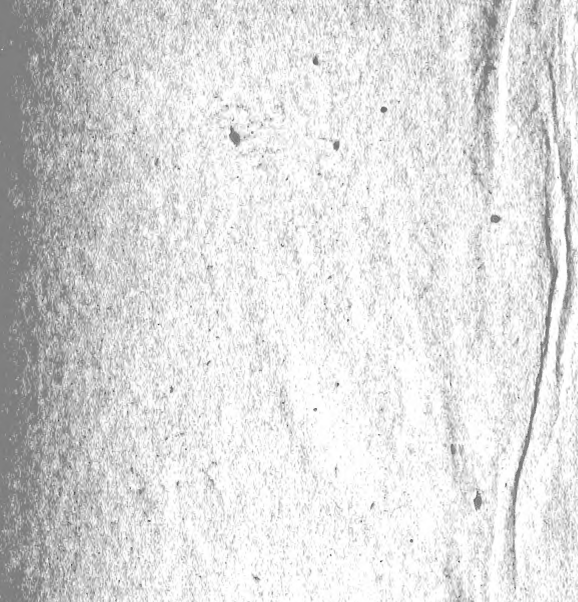

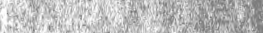
tor.

$\cos (\sin 2)$

(2)

2(x)

4.

1.20

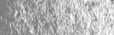

Noterich

(2)

42.

$5+2 x^{2}$

$x^{2}+x^{2}$

1.

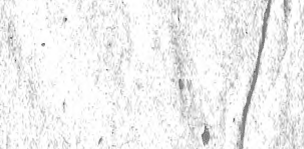

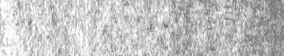

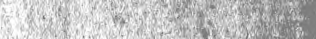

Ty

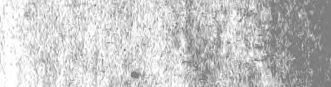

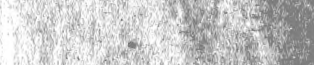

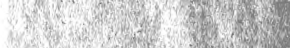
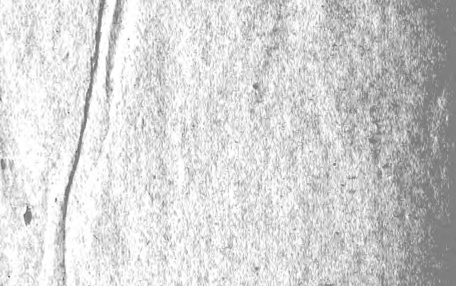

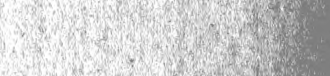
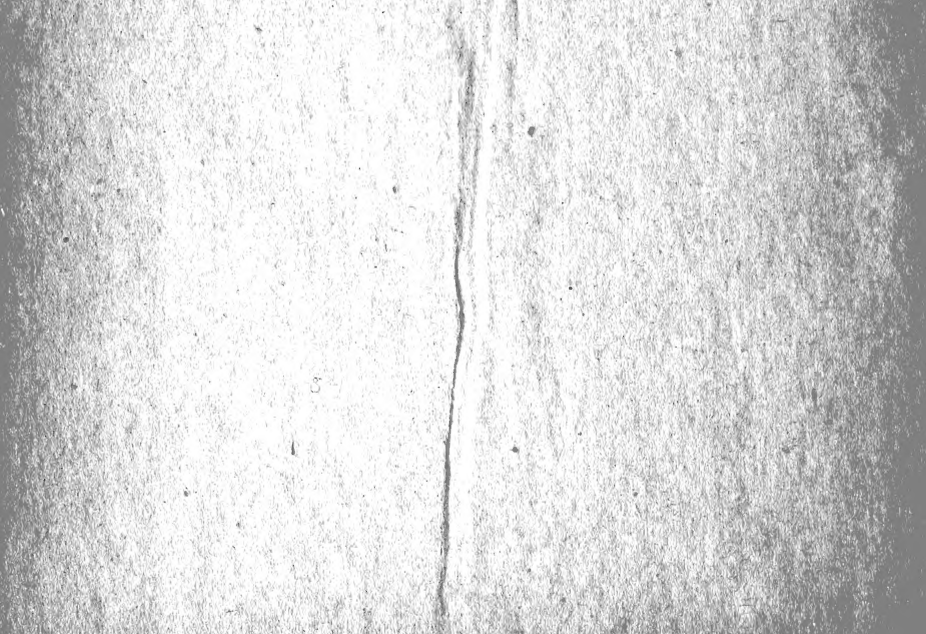

$$
\text { (3) } x^{2}
$$$$
\text { 16. }
$$$$
\text { a }
$$

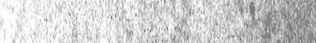

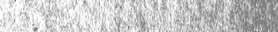

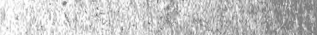

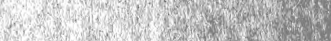
3.

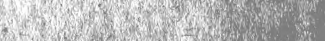

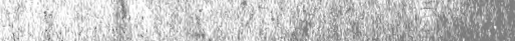




\section{LIBRARY \\ FACULTY OF FORESTRY \\ UNIVERSITY OF TORONTO}

SD

143

B35

1894

Forestry

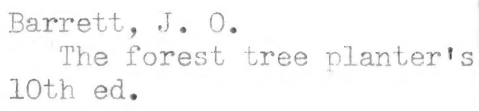

PLEASE DO NOT REMOVE CARDS OR SLIPS FROM THIS POCKET

UNIVERSITY OF TORONTO LIBRARY 
